NBER WORKING PAPER SERIES

\title{
LEARNING TO NAVIGATE A NEW FINANCIAL TECHNOLOGY: EVIDENCE FROM PAYROLL ACCOUNTS
}

\author{
Emily Breza \\ Martin Kanz \\ Leora F. Klapper \\ Working Paper 28249 \\ http://www.nber.org/papers/w28249 \\ NATIONAL BUREAU OF ECONOMIC RESEARCH \\ 1050 Massachusetts Avenue \\ Cambridge, MA 02138 \\ December 2020
}

We are grateful to Pierre Bachas, Shawn Cole, Xavier Giné, Jessica Goldberg, Rawley Heimer, Supreet Kaur, Michael Kremer, Rocco Machiavello, David McKenzie, Simone Schaner, Lore Vandewalle and numerous seminar and conference participants for helpful comments and suggestions. Financial support from the Asian Development Bank, Innovations for Poverty Action Global Financial Inclusion Initiative, International Growth Centre, U.S. Department of Labor, and the World Bank is gratefully acknowledged. This study was approved by the Harvard and Columbia University Institutional Review Boards and registered in the American Economic Association Registry for randomized control trials (AEARCTR-0001107). Camilla Fabbri, Maura Farrell, Rayhanul Islam, Michel Nehme, Smita Nimilita, Minita Varghese, and Rebecca Wu provided outstanding research assistance. The opinions expressed in this paper do not necessarily reflect the views of the World Bank, its executive directors or the countries they represent. The views expressed herein are those of the authors and do not necessarily reflect the views of the National Bureau of Economic Research.

NBER working papers are circulated for discussion and comment purposes. They have not been peer-reviewed or been subject to the review by the NBER Board of Directors that accompanies official NBER publications.

(C) 2020 by Emily Breza, Martin Kanz, and Leora F. Klapper. All rights reserved. Short sections of text, not to exceed two paragraphs, may be quoted without explicit permission provided that full credit, including $\odot$ notice, is given to the source. 
Learning to Navigate a New Financial Technology: Evidence from Payroll Accounts

Emily Breza, Martin Kanz, and Leora F. Klapper

NBER Working Paper No. 28249

December 2020

JEL No. G21,G5,O16

\begin{abstract}
$\underline{\text { ABSTRACT }}$
How do inexperienced consumers learn to use a new financial technology? We present results from a field experiment that introduced payroll accounts in a population of largely unbanked factory workers in Bangladesh. In the experiment, workers in a treatment group received monthly wage payments into a bank or mobile money account while workers in a control group continued to receive wages in cash, with a subset also receiving an account without automatic wage payments. We find that exposure to payroll accounts leads to increased account use and consumer learning. Those receiving accounts with automatic wage payments learn to use the account without assistance, begin to use a wider set of account features, and learn to avoid illicit fees, which are common in emerging markets for consumer finance. The treatments have real effects, leading to increased savings and improvements in the ability to cope with unanticipated economic shocks. We conduct an additional audit study and find suggestive evidence of market externalities from consumer learning: mobile money agents are less likely to overcharge inexperienced customers in areas with higher levels of payroll account adoption. This suggests potentially important equilibrium effects of introducing accounts at scale.
\end{abstract}

\author{
Emily Breza \\ Harvard University \\ Littauer Center, M28 \\ 1805 Cambridge Street \\ Cambridge, MA 02138 \\ and NBER \\ ebreza@fas.harvard.edu \\ Martin Kanz \\ The World Bank \\ 1818 H Street NW \\ Washington, DC 20433 \\ mkanz@worldbank.org
}

Leora F. Klapper

The World Bank

1818 H Street, NW

Washington, DC 20433

lklapper@worldbank.org 


\section{Introduction}

The last decade has seen an unprecedented expansion in access to consumer financial products, with an estimated 1.2 billion adults gaining access to a bank or mobile money account over this period (World Bank, 2017). While this has expanded the financial tools available to households, there is also widespread concern that financial intermediaries can profit from exploiting inexperienced consumers (Campbell et al., 2011). This is especially true in developing economies where financial access has expanded rapidly against the backdrop of enormous variation in consumer experience and sophistication (Agarwal et al., 2018; Anagol et al., 2017; Badarinza et al., 2019).

This proliferation of new financial products and technologies has been accompanied by an extensive debate about the tradeoff between access and consumer protection. Some regulators have argued that predatory practices are sufficiently widespread to warrant outright limits to access, fees, and product features - potentially at the expense of gains from broader financial inclusion. ${ }^{1}$ Proponents of lighter regulation, on the other hand, have advocated for information-based policies that instead aim to increase transparency to strengthen consumer knowledge and sophistication.

An important open question at the heart of this debate is to what extent risks to consumers can be mitigated by "learning-by-doing" that occurs naturally, as new financial technologies are introduced at scale and used on an everyday basis. Studying this question is empirically challenging for several reasons. First, the typically high degree of selection into adoption and active use of new financial technologies requires a setting with exogenous variation in access as well as incentives to engage with the technology to identify consumer learning. Second, many types of consumer protection risks, such as side payments to intermediaries, are difficult to observe in administrative data and may require surveys, audit studies, and other non-traditional data to be accurately measured.

In this paper, we study consumer learning in the context of payroll accounts, a simple financial technology that is currently being rolled out to millions of workers worldwide in response to demands for increased supply chain transparency and as a result of the Covid-19 pandemic. ${ }^{2,3}$ We conduct a field experiment with a population of salaried factory workers in Bangladesh who, prior to our study, received their wages entirely in cash. In the experiment, workers were randomly assigned to either continue receiving wages in cash, or begin receiving wage payments into a bank or mobile money payroll account. In a set of comparison treatments, workers were given an account but

\footnotetext{
${ }^{1}$ See, Mullainathan et al. (2009), and Beshears et al. (2018) for perspectives on behaviorally informed regulation, and Agarwal et al. (2015) on the effectiveness of current consumer financial protection regulation.

${ }^{2}$ More than $50 \%$ of employees globally and $85 \%$ of employees in developing countries receive wages in cash. Approximately 300 million individuals earn regular verifiable wage income but do not have access to a formal financial account (Demirgüç-Kunt et al., 2017). In response to allegations of widespread labor rights and minimum wage violations, many international brands have started to require suppliers to pay employees into digital payroll accounts. This, in turn, has led entire industries to begin digitizing wage payments to their global workforce. See, for example, "Fashion Brands Team Up To Spearhead Campaign Around Wage Transparency", Forbes November 5, 2019.

${ }^{3}$ Several countries, including Bangladesh where our study is set, have made government bailouts during the pandemic conditional on firms phasing out in-person cash payments and introducing payroll accounts for workers.
} 
continued receiving monthly wage payments in cash. We measure treatment effects on learning and real outcomes using panel of surveys as well as administrative data. We also employ a machine learning approach (Chernozhukov et al. 2018) to understand which types of consumers are able to learn how to use the financial technology in a more effective manner through exposure to payroll accounts. We additionally examine the market-level implications of consumer learning with a complementary audit study that examines how the prevalence of illicit extra charges changes as consumer sophistication in the market increases and information asymmetries between consumers and financial intermediaries are diminished.

The setting of our experiment has several attractive features that help us trace how individuals engage with accounts and learn to overcome consumer protection challenges associated with a new financial technology. First, electronic payroll accounts are a financial technology with potentially high returns to adoption that is currently being introduced to millions of workers worldwide. At the same time, payroll accounts are susceptible to many common consumer financial protection problems, such as shrouded fees, commission-based incentives, and barriers to use among inexperienced consumers. Second, we measure behaviors and real outcomes, using comprehensive administrative data that captures all financial transactions made by study participants as well as self-reported survey data. Third, we are able to examine consumer learning in a controlled environment that allows us to induce random variation in access as well as incentives to use the technology among individuals in the same workplace environment. We hypothesize that being given an account alone lowers transaction costs and facilitates savings on the extensive margin by relaxing constraints related to account opening. Adding direct deposit wage payments provides an incentive to actively engage with the account on the intensive margin. This variation in the intensity of account use, generated by our experimental design, in turn allows us to identify whether frequent use causes consumers to learn how to use the financial technology in a more efficient and cost-saving manner.

We find compelling evidence of consumer learning as a result of active engagement with the financial technology. Our payroll account treatments increase active engagement with the account and cause consumers to learn how to use the features of the technology to their advantage. While direct deposits lead, mechanically, to more withdrawal and cash-out transactions, participants in the treatment group also make more deposits, send-money transactions, and accumulate higher account balances. We document consumer learning using two main outcomes. Our first outcome, outside transactions, is an indicator for the likelihood of a worker making a transaction outside the workplace, where help with accessing the account is not readily available. Our second learning outcome direct transactions focuses on mobile accounts, and measures whether participants learn to transact through their account without the help of a mobile money agent, thereby sidestepping illicit extra charges which are widespread in our setting and many other markets for consumer finance. ${ }^{4}$

\footnotetext{
${ }^{4}$ Annan (2019) shows that in Ghana consumers are overcharged in $20 \%$ of all mobile money transactions, with female customers being more than $90 \%$ more likely to be the victim of financial agent misconduct. See also the "Nigeria Financial Services Agent Survey" (EFINA, 2020), which shows that $40 \%$ of financial services agents in
} 
We find learning effects along both of these dimensions. Most substantively for worker welfare, those receiving direct deposits into a mobile account are less likely to make costly over-the-counter transfers brokered by intermediaries, which are banned by the platform, but extremely common in our worker population. Notably, the treatments do not change the number or frequency of transfers to others. Moreover, the differential impacts of direct deposit relative to account only on illicit fees cannot be explained by differences in transaction costs alone. ${ }^{5}$ Thus, direct deposits induce learning about the financial accounts and help to partially mitigate the kinds of consumer protection issues that are common in settings with limited capacity for regulating consumer transactions.

The learning and consumer protection impacts from receiving a payroll account are accompanied by an increase in trust, as measured by whether the respondent would feel comfortable leaving BDT 1,000 (US\$12) in an account. ${ }^{6}$ This effect is most pronounced for mobile money accounts - the more novel and technologically demanding type of account used in our study. While baseline trust in bank accounts $(56 \%)$ is substantially higher than trust in mobile money accounts (38\%), our intervention eliminates this trust gap almost entirely for individuals who are given a payroll account.

Our treatments also affect real outcomes, including savings and the ability to cope with unanticipated shocks. Receiving wage payments into a formal account causes a large increase in formal and overall savings at all measured time horizons. Specifically, our intervention increases the likelihood of having any savings by 4-11 percentage points and more than doubles the likelihood of individuals having savings in a formal account from a base of $25 \%$. In contrast, simply providing an account has much smaller and often undetectable impacts on savings. Our results suggest that workers both shift resources from informal to formal vehicles and generate new savings by reducing discretionary consumption as a result of receiving direct deposit wage payments. In line with prior research, on account ownership and savings we also find evidence that our treatments improved the ability of workers to smooth consumption. Workers receiving direct deposits report fewer instances where they were unable to mitigate an unforeseen shock due to lack of resources. However, we cannot statistically distinguish these effects from the account only group.

In the second part of our analysis, we examine which characteristics shape an individual's ability to learn how to optimally use the technology. Rather than search for treatment effect heterogeneity trait-by-trait, we use the machine learning (ML) approach proposed by Chernozhukov et al. (2018) to let the data reveal patterns of heterogeneity. We detect no heterogeneity in our main savings and consumption smoothing outcomes, which suggests equal gains through exposure for all groups. The ML procedure does detect heterogeneous impacts on consumption and consumer learning.

Nigeria overcharged consumers and the "Financial Inclusion Insights Survey" (CGAP, 2018), which finds that 12\% of mobile money customers in Bangladesh noticed that they were being overcharged. The actual incidence is likely much higher.

${ }^{5}$ For individuals with their own account, a person-to-person transaction requires visiting an agent to perform a cash in transaction and then executing a simple transfer on the mobile phone. An over-the-counter transaction requires visiting the same agent to make the transfer.

${ }^{6}$ We use the exchange rate as of May 2014, the start date of our experiment, for all currency conversions. 
Interestingly, the ML tool partitions the sample into "savers" and "learners." The "savers" cut discretionary consumption to generate new savings, but do not experience large learning-by-doing gains, while the "learners" do not cut consumption by as much but experience large learning-bydoing gains. "Savers" are more likely to be females, parents, in positions of low levels of household resource control, and those with low levels of education and experience with financial products. In contrast, "learners" are more likely to be men, those without children, those with higher levels of education, and prior financial access. These results suggest that while the benefits of direct deposits and accounts are spread throughout the population of workers, consumer protection gains from learning-by-doing are largely experienced by those with some prior financial access. More far-reaching interventions may be needed to benefit the least experienced users.

Finally, we ask whether consumer learning generates positive externalities at the market level. We examine this question through an audit study that we conducted in neighborhoods surrounding our study location which differ in the local level of payroll account adoption. In the audit study, factory workers were assigned to visit mobile money agents located in neighborhoods with high versus low levels of payroll account penetration and ask for assistance with a simple financial transaction. The outcome of interest is whether consumers are charged an extra fee for the transaction, which is a practice that is banned by the platform, but extremely common in practice. We find that mobile money agents are significantly less likely to overcharge inexperienced workers in areas with higher payroll account penetration. Specifically, we find that the same worker is 15 percentage points less likely to be overcharged in an area with above-median payroll account penetration. This result is robust to controlling for supply-side factors, such as the density of the agent network, suggests that unsophisticated users stand to benefit as the average user becomes better informed, and implies positive externalities from consumer learning.

Taken together, our results show that financially inexperienced consumers can benefit substantially from payroll accounts when the employer and financial service providers play active roles in the process. Our results reveal that the benefits of payroll accounts arise from two separate channels: the direct benefits of account ownership, as well as the benefits of "learning-by-doing" that generate tangible consumer protection benefits. Subsidizing, rather than restricting, the use of new financial technologies may therefore be an effective approach to reducing some types of consumer protection risks. The results also suggest where scarce regulatory resources should be targeted toward women and less financially included and experienced populations.

Our paper contributes to three strands of the literature. First, we contribute to a literature on new financial products and consumer protection. While new financial technologies have many features that are helpful to consumers (see Bachas et al. 2017; Carlin et al. 2017; Suri 2017), they may also generate risks, especially for populations with low levels of financial literacy and experience (see Campbell et al. 2011). Several studies show that lenders target less educated consumers and strategically exploit information asymmetries and behavioral biases in a way that harms consumers 
(Gabaix and Laibson, 2006; Bertrand and Morse, 2011; Dobbie and Skiba, 2013; Giné et al., 2014, 2017). Similarly, in many consumer finance settings, financial intermediaries face incentives to sell commissions-based services, rather than services that minimize costs for the consumer (see Anagol et al. 2017, 2020 and Egan et al. 2019). While there is a small literature showing that individuals learn from their financial experiences (Anagol et al. 2020), there is little evidence on whether "learningby-doing" can enable consumers to avoid common risks over time. Two notable exceptions are Giné and Goldberg (2020), who show that inexperienced consumers who were induced to actively use a bank account are more likely to choose a lower-cost account when given the option later on and Brown, Cookson and Heimer (2019) who study the introduction of bank branches on Native American reservations and show that consumers who are exposed to formal accounts earlier in life have better credit scores and long-term credit outcomes. We shed light on these issues by examining whether active engagement with a financial technology helps consumers learn to use its features to their advantage and avoid common consumer financial protection risks.

Second, our results speak to the literature on financial inclusion. A large body of research has documented high demand for bank and mobile accounts among the unbanked and illustrated various benefits of account ownership (see Aker et al. 2020; Batista et al. 2018; Breza and Chandrasekhar 2019; Callen et al. 2019; Jack and Suri 2014, 2016; Schaner 2018). Burgess and Pande (2005) and Bruhn and Love (2014), for example, study branch banking expansion and find positive impacts on income levels and poverty reduction. At the same time, account opening drives led by governments and the private sector have often been unsuccessful at encouraging active engagement with formal accounts. Agarwal et al. (2018) study the world's largest financial inclusion program, under which 255 million bank accounts were opened in India and report that more than $80 \%$ of account holders do not make a single deposit or withdrawal within six months of account opening. We contribute to this line of research by documenting real impacts of payroll accounts and consumer learning.

Third, our results add to a literature that has examined how commitment features and default assignments in financial products can incentivize account use and generate behavioral change (see Madrian and Shea 2001; Beshears et al. 2018, 2020; Blumenstock et al. 2018; Somville and Vandewalle 2018; Dupas and Robinson 2013; Riley 2020). ${ }^{7}$ Such commitment features are increasingly being used to incentivize active engagement with accounts, for example by channeling government transfer payments into bank or mobile accounts. ${ }^{8}$ Our study uses the assignment to payroll accounts, a technology that generates similarly strong incentives to actively engage with an account, to examine impacts on consumer learning and real outcomes.

The remainder of the paper is structured as follows. In Section 2, we describe the context, setting

\footnotetext{
${ }^{7}$ See also Breza et al. (2018) who examine signaling motivations in the demand for commitment savings products.

${ }^{8}$ See, for example, Muralidharan et al. 2016; Field et al. 2018, who study accounts opened alongside a large workfare program in India, or Bachas et al. (2017) who study debit cards rolled out as part of the Oportunidades conditional cash transfers program in Mexico. See also Haushofer and Shapiro (2016) who study the impact of unconditional cash transfers into mobile accounts.
} 
and design of our study. Section 3 describes our data sources and presents descriptive statistics. Section 4 presents our empirical strategy and experimental results, while Section 5 presents the design and results of the supplemental audit study. Section 6 concludes.

\section{Background and Research Design}

\subsection{Payroll Accounts for Low-Income Workers}

We study consumer learning in the context of a simple financial technology: payroll accounts for low-income workers. Despite rapid advances in financial inclusion, cash wage payments are still the norm in low and middle-income economies. Approximately $85 \%$ of all salaried employees in developing economies receive their wages in cash and are often unable to open a formal financial account without the assistance of their employer, despite having documented regular income. ${ }^{9}$

The introduction of employer-sponsored payroll accounts addresses the inefficiencies of cash wage payments from the perspective of the firm as well as that of the employee.From the firm's perspective, payroll accounts are efficiency-improving because they dramatically reduce transaction costs of administering regular wage payments. Payroll accounts also reduce the scope for corruption and wage theft, as well as security and insurance costs associated with disbursing wages in cash. With the increasing integration of international supply chains, firms have faced greater calls for wage transparency and adherence to international labor standards, often as a prerequisite for doing business with large multinational buyers in the export market. ${ }^{10}$ The introduction of payroll accounts reduces the scope for violations of minimum wage laws and limits on weekly work hours and enables employers to transparently document wage payments to employees. More recently, the Covid-19 pandemic has led to a dramatic increase in the use of payroll accounts globally, as many firms have sought to phase out cash payments that require person-to-person interactions. Many countries have, in fact, made it mandatory for employers to phase out cash payments. In Bangladesh, the government made a bailout for the garment sector conditional on the introduction of payroll accounts for workers, which led to 800 firms digitizing wage payments for more than one million workers within one month. ${ }^{11}$

From the employee's perspective, payroll accounts are attractive because of their potential financial inclusion benefits. The majority of salaried employees around the world remain unbanked and face significant barriers that prevent them from accessing a formal account. Such barriers

\footnotetext{
${ }^{9}$ See Demirgüç-Kunt et al. (2017) for details and additional statistics on financial inclusion around the world.

${ }^{10}$ In many industries, including the garment manufacturing sector where our study is set, paying wages through payroll accounts is increasingly becoming a requirement for doing business with large buyers in the export market. These requirements have largely taken effect after we completed our intervention and have led to a steep worldwide increase in the adoption of payroll accounts. Relatedly, Boudreau (2020) shows how multinational enforcement of labor regulations can improve compliance and worker safety.

${ }^{11}$ See "Scaling the Impact of Digital Financial Services: The Opportunity and Imperative during Covid-19". Mastercard Center for Inclusive Growth, September 2020.
} 
include prohibitive minimum balance and documentation requirements and a wide range of social constraints that prevent inexperienced customers from engaging with the formal banking system. Payroll accounts typically do not have minimum balance requirements, allow the employer to submit documentation on behalf of the employee, and can reduce social barriers to account use by making accounts mandatory and providing training and banking facilities near the workplace. ${ }^{12}$ Payroll accounts are also typically portable and remain accessible to the employee even after the employment relationship has ended, and potentially provide a pathway to the use of other financial products. Because payroll accounts generate an inherent incentive to actively engage with a formal account, they are likely to have additional inclusion benefits, similar to those that have been shown in the case of direct deposit government payments and other financial products with a default component (see Muralidharan et al. 2016, Blumenstock et al. 2018, and Callen et al. 2019).

Traditionally, payroll accounts have used the conventional banking infrastructure, channeling paychecks into deposit accounts. However, in many developing economies, the limited reach of the physical banking infrastructure has hampered the expansion of payroll accounts. In recent years, mobile money technologies have been able to successfully address these challenges by establishing a decentralized network of mobile money agents. ${ }^{13}$ In addition, financial service providers have used mobile money technologies to develop hybrid payroll account products that combine the advantages of bank and mobile money accounts. ${ }^{14}$ In order to shed light on the comparative advantages of different types of payroll accounts, we use bank and mobile money accounts in our experiment.

Because consumers access mobile money accounts through commissions-motivated intermediaries (mobile money agents), their widespread adoption raises a number of consumer protection issues that go beyond those present in conventional banking (see Anagol et al. 2017). While access to a mobile money account reduces transaction costs, inexperienced customers often require assistance to use their account and do not use the technology in the most cost-effective way. Instead of transferring money from person-to-person using their own account, many inexperienced users require the help of an intermediary and make transfers using agent-to-agent transactions that incur additional fees on both ends of the transaction. Although the practice is officially not permitted by mobile money providers in our setting, it is extremely widespread. In our audit study, we find that agents overcharge consumers in $31 \%$ of all transactions. Similarly, inexperienced workers may be unable to use their account without an intermediary and may be prone to disclose passwords and other identifying information to mobile agents or peers to help them access their

\footnotetext{
${ }^{12}$ In our population, most workers could not have opened accounts without the assistance of their employers. The firm, for example, provided employment records and identification data directly to the partner financial institutions. Formal account ownership at baseline was rare, and it was not possible to link wage payments to pre-existing accounts.

${ }^{13}$ Mobile money also offers additional features and functionality that traditional bank accounts lack, and that may make mobile money more useful for certain types of transactions such as remittances. In our experiment we use accounts that permit person-to-person transactions, the ability to cash in or out at any registered agent in the nationwide network, the ability to make direct payments, and airtime purchases from mobile providers.

${ }^{14}$ See Suri (2017) for an overview of the literature on mobile money.
} 
account, which raises additional consumer protection concerns. One question we ask in this study is whether repeated interaction with the financial technology through direct deposit wage payments enables inexperienced customers learn to use accounts in a more cost-saving manner and avoid these common consumer protection risks.

\subsection{Setting and Sample Population}

We conduct our study with workers in the garment manufacturing industry in Bangladesh. The ready-made garment sector is one of the largest exporting industries globally and among the most important sources of formal employment in the developing world. Bangladesh currently ranks as the world's second largest exporter of ready-made garments, just behind China, and the country's large garment industry accounts for approximately $20 \%$ of the country's GDP and $85 \%$ of the nation's $\$ 40$ billion in annual exports. ${ }^{15}$

The labor force employed in Bangladesh's garment manufacturing sector has grown at an annual rate of $17 \%$ since 1980 . Today, garment manufacturing firms in the sector employ approximately 4 million workers, of which $80 \%$ are female (Heath and Mobarak 2015). Many workers from rural areas are drawn to the relatively high, regular salaries paid in the garment industry and aim to save a portion of their paychecks. However, owing to high account maintenance fees, minimum balance requirements, and documentation requirements, workers in the garment sector are usually unbanked. At the time of our intervention, even large firms in the sector still paid wages entirely in cash. Moreover, there are significant social barriers that prevent low-income households from active participation in the formal banking system. Anecdotally, many workers reported not feeling comfortable using bank branches or mobile money agents, despite having clear savings goals. These characteristics make the setting ideal for studying how individuals learn about financial products - there is a clear unmet demand for savings products and other financial services, but low baseline literacy, social barriers, and the incentives of agents limit the ability for workers to learn.

The population for our study consists of workers employed by two large garment manufacturing firms located in greater Dhaka, Bangladesh. Workers in the sample were selected from the universe of production workers employed by these firms at the time of our baseline survey. The firms provided us with full lists of their manufacturing line workers. Workers are assigned to one of several salary grades, based on seniority and task. We exclude workers at the lowest seniority level, which consists of workers whose tenure at the firm is too temporary to warrant opening a formal payroll account. This leaves us with a sample of 3,136 workers who participated in our experiment.

\footnotetext{
${ }^{15}$ See Machiavello et al. (2020a) and Machiavello et al. (2020b) for studies set in the same context.
} 


\subsection{Experimental Treatments}

Prior to our study, all workers in the sample received monthly wage payments entirely in cash. The treatment conditions of our experiment randomly assigned workers to receive their wage payments through different channels: ${ }^{16}$ workers were assigned either to a control group that continued to receive wage payments in cash, a treatment group in which workers received direct deposit wage payments into a payroll account, or a treatment group in which workers were provided with an account but continued to receive wage payments in cash.

Control group. We assigned 728 (23\%) workers to a control group, in which workers continued to receive wage payments in cash. Workers assigned to this treatment were paid once a month and received their wage payments in cash on the firm's premises following the same protocol that was in place prior to our study.

Bank or mobile payroll. We assigned a total of 1,757 (56\%) workers to our main treatment group, the bank or mobile payroll treatment condition. Within this group, the partner firm opened bank payroll accounts for 884 workers and mobile payroll accounts for 873 workers. Workers received a payroll account with monthly direct deposit wage payments. ${ }^{17}$ Workers who received a bank payroll account were provided with a debit card that they could use for withdrawals at an ATM installed on the factory premises, or at bank branches, ATMs, and stores outside the workplace. For workers assigned to receive a mobile money account, the partner firm opened a payroll account with Bangladesh's most popular mobile money platform, which is widely used among all segments of the population and has an extensive agent network throughout the country. ${ }^{18}$ Whenever a worker was assigned to a mobile payroll account, we additionally issued the worker a personal SIM card linked to their account to ensure that accounts could be accessed reliably and that workers were not dependent on linking their account to a phone number that is not their own. ${ }^{19}$ Any worker who did not have reliable access to a mobile phone was encouraged to opt out of the payroll component of their account, but still received a non-payroll account. ${ }^{20}$

Bank or mobile account In order to separate the effect of receiving direct deposit wage payments into an account from the effect of account opening alone, we assigned a total of 651 workers $(21 \%)$ to a bank or mobile account treatment group. Within this group, our partner firm

\footnotetext{
${ }^{16}$ Because of the substantial fixed costs of setting up the intervention at each participating firm, we use a within-firm randomization. To the extent that workers in the control group receive spillovers from treated workers, we should expect that to make it harder to detect impacts of our payroll treatment relative to the other conditions. We test for the presence of spillover effects directly in Appendix D.2.

${ }^{17}$ Workers could opt out of the treatment if they were not able to access the account securely or did not wish to receive direct deposit wage payments for any other reason.

${ }^{18}$ In 2018, the platform had more than 30 million active users, a network of more than 160,000 agents in all parts of the country, and a market share of over $90 \%$.

${ }^{19}$ In a separate exercise, we experimented with additionally providing a random set of participants who did not have primary access to a phone with their own mobile phone. The results do not alter our main findings and are available upon request.

${ }^{20}$ As described below, we use an intent-to-treat (ITT) research design.
} 
opened 201 bank accounts and 450 mobile money accounts, but continued to pay monthly wages in cash so that use of the account was entirely optional. Workers in the bank or mobile account group were free to use the same ATMs and mobile money agents at or outside the workplace that were also available to participants in the payroll account group. As in the payroll account group, workers who received a mobile money account were additionally issued a personal SIM card to ensure reliable access to their account.

To hold the cost of access constant across the two types of accounts, our partner firms installed ATMs and stationary mobile money agents on the factory premises. ${ }^{21}$ While the mobile agents offered full service, the ATMs were only capable of withdrawals and did not accept deposits. In addition, all account opening and transaction fees were reimbursed for the duration our study. ${ }^{22,23}$ Throughout the study, a staff member was available on the factory premises to help workers with any technical difficulties or problems accessing their account. This was an especially important step in our setting, where baseline trust in accounts is very low and any problems accessing the account in the early trial period are very likely to cause participants to abandon the technology and revert to cash. $^{24}$

\subsection{Treatment Implementation}

Within our sample frame of 3,136 workers, treatment was randomized at the individual worker level. Because randomization was conducted sequentially at each partner firm, we stratified treatment by firm. Within firm, we further stratified on worker gender and salary grade.

Because collecting the required paperwork, processing account opening documents, and initiating electronic wage payments was a relatively time-consuming process, we rolled out the experimental treatments in multiple phases over a 12 -month period at each study location. ${ }^{25}$ Individuals were randomized to both a treatment and an implementation date prior to the beginning of the intervention. Worker turnover is high in our setting, and we therefore obtained updated staff lists prior to each round of implementation and sampled from a replacement list in case a worker was no longer employed at the firm on their assigned treatment date. Members of the survey team visited study locations ahead of each phase of the account roll-out and conducted training sessions for

\footnotetext{
${ }^{21}$ The bank and mobile money partner institutions ensured that the ATMs and mobile agents had sufficient cash to meet the demands of workers on pay day.

${ }^{22}$ The main charges when using a mobile money account are cash-out fees which, at the time of our study was 1.9 percent of the transaction amount. In the payroll account treatment, we reimbursed an amount equivalent to the hypothetical fee that would be charged if the worker withdrew her entire salary.

${ }^{23}$ The industry standard in Bangladesh is for the firm to pay any fixed account fees, but for the workers themselves to pay cash-out fees. The results of our study thus represent a no-fee benchmark.

${ }^{24}$ This was, in fact, a dynamic we documented in several pilots. We interpret this as suggestive evidence that the introduction of simple financial technologies, such as the one we study, may be prone to fail in inexperienced populations unless all aspects are implemented well (see Kremer 1993). This is also supported by pilot tests that we conducted prior to our study, in which technical problems in the early stages of adopting the financial technology were a main reason for participants to opt out of payroll accounts in favor of cash payments.

${ }^{25}$ The main experiment was conducted between November 1, 2014 and December 1, 2016.
} 
workers assigned to receive an account. The training sessions were designed to familiarize workers with the features and functionality of the account, but did not contain any additional financial education content. ${ }^{26}$

We use an intent-to-treat (ITT) analysis in all of our main specifications. There are several reasons why actual treatment and assigned treatment might differ. First, some individuals left the factory before being treated. While our policy was to only announce treatment status one month prior to the actual treatment date, we conduct our analysis on the full set of workers present in the factory before the first treatment phase was announced. Second, a small number of individuals opted out of receiving the direct deposit component of the payroll account. Third, the bank and mobile money partners rejected a number of account applications due to insufficient documentation. ${ }^{27}$ Finally, in some cases, account opening took longer than one month, thus delaying the actual treatment date. In our panel analysis of the follow-up surveys, we therefore use intended rather than actual treatment date in our main regression specifications. We present the first-stage relationship between assigned and actual treatment in Appendix Table D.3. On average, $92 \%$ of individuals assigned to the bank or mobile payroll treatment received the treatment and $90 \%$ of individuals assigned to the account only treatment eventually received an account. The difference is not statistically significant $(\mathrm{p}$-value $=0.407)$.

\section{$3 \quad$ Data and Descriptive Statistics}

To analyze how exposure to payroll accounts affects behaviors and real outcomes, we combine multiple rounds of survey data with administrative records that capture the universe of financial transactions made through mobile and bank accounts assigned as part of our study. These data cover a time period of approximately two years, during which our field experiment was conducted. ${ }^{28}$

\subsection{Survey Data}

Our main data source consists of a comprehensive baseline and endline survey, as well as five rounds of shorter midline surveys, administered over a period of approximately two years. Before being assigned to one of the experimental treatments, each worker completed a baseline survey that included modules on demographics, savings, consumption, household finances, financial literacy,

\footnotetext{
${ }^{26}$ Our implementation provided extensive training and assistance with accounts. Thus, our results highlight the potential benefits of payroll technologies under a best-case scenario and are likely an upper bound, relative to adoption in a less controlled setting.

${ }^{27}$ Both financial partners required all workers to pass a "know your client" (KYC) document review, mandated by the regulator, before opening an account. The most common reason for rejection at this step were inconsistencies in the worker's national ID card. For example, some workers' ID cards had their photograph, but an incorrect first or middle name, or different spelling than in other documents. The lack of unique identification and straightforward procedures for proof of identity is an important barrier to financial inclusion facing many developing countries.

${ }^{28}$ See Appendix B for a timeline of our intervention, survey rounds, and additional data collection.
} 
and planning. In total 3,136 study participants completed the baseline survey, of which 2,749 were successfully assigned to one of the treatment groups. Workers then completed periodic followup surveys that were much shorter than the baseline survey and focused primarily on questions relating to ongoing expenditures and financial decisions. We administered a comprehensive endline survey approximately 18 months after the first participants were enrolled in the study and received an account. The endline survey was completed by 2,376 of the 3,136 respondents of the baseline survey. ${ }^{29}$ Of the participants in this sample, 1,109 completed the full panel of baseline, follow-up, and endline surveys. ${ }^{30}$

Table 1 reports summary statistics for our sample, using data from the baseline survey. The average respondent in our sample is female, has been employed at the firm for three years, and earns a monthly base salary of BDT 6,779 (US\$80). On average, workers in our sample have completed only elementary school, $57 \%$ are not literate, and many workers in our sample also struggle with numeracy, as reflected in comparatively low average scores on a digit span test. While most respondents in our sample state that they plan to save, many are unable to meet their savings goals: $22 \%$ of our respondents would not be able to save BDT 5,000 for emergency expenses, $47 \%$ needed to borrow at the end of the month, and $65 \%$ report having difficulty sticking to financial plans.

Workers in our sample have very little experience using formal financial services and low trust in formal accounts. While a high share of workers stated that they planned to save, only $25 \%$ report had savings in any formal account at baseline. The median worker sends monthly remittances worth approximately $22 \%$ of her monthly base salary, indicating high demand for remittance services. While seventy-five percent had used a mobile payments platform to send money, very few used their own account - less than $1 \%$ had a balance in a mobile account. The use of informal financial services, on the other hand, is widespread: $33 \%$ of workers had informal savings, such as keeping cash at home or with local savings groups, while approximately half of all participants had informal loans outstanding, typically at extremely high interest rates.

The baseline summary statistics also reveal extremely low trust in formal accounts. We asked respondents "would you be comfortable leaving BDT 1,000 in a [bank or mobile] account for 30 days?". Answers were given on a 10-point scale. Averaging across bank and mobile responses, the mean report is 3.7. Panel (a) of Figure 1 splits the sample into groups who report $>5$ versus $<=5$ on the trust question, averaged over account type. $73 \%$ of respondents fall into the low average trust category. ${ }^{31}$ Figure 1, panel (b) shows that trust in formal accounts is even lower

\footnotetext{
${ }^{29}$ At one study location, the first follow-up survey was conducted before treatment assignments had been revealed. In that location, we restrict our sample to individuals still working in the factory at the time of that follow-up.

${ }^{30}$ In some of the follow-up rounds, we did not have the permission of the factories to survey the full set of participants. In these "thin" rounds, we randomized which workers were contacted. This explains why the set of workers with a full panel is much smaller than the set of workers who completed an endline survey.

${ }^{31}$ Focus group discussions suggest that workers are worried about being overcharged by financial agents in regular transactions as well as the lower probability event that an agent fraudulently uses personal account information to
} 
among respondents that have never used a bank or mobile account. ${ }^{32}$ Figure 2 reports summary statistics on respondents' confidence using the formal financial services. The figure plots responses to the question "how comfortable are you making a transaction at a bank branch or mobile money agent?". Figure 2, panel (a) shows that a large majority of respondents in our sample are not comfortable using bank branches or mobile money agents, and Figure 2, panel (b) shows that this is even more true for respondents in the low-experience sample who have not used a bank or mobile account before.

\subsection{Administrative Data}

In addition to the survey data, we obtained detailed transaction data for all participant accounts in our study. With the consent of participants, our partner bank and mobile money provider shared data on monthly account balances and the universe of transactions made in all accounts linked to our study. Each transaction record in this data set includes the transaction time, location, as well as information on the transaction type and fees charged. In total, this data set covers 903 bank accounts, 1,093 mobile accounts and records 82,055 individual transactions over a period of approximately two years. These data enable us to study consumer learning by comparing account usage over time between those receiving a payroll account versus a simple account. Moreover, access to the administrative data allows us to supplement and validate the survey responses. Notably, the administrative data reflects the full universe of workers receiving any account and is free from attrition concerns and concerns of enumerator demand effects. Having access to the complete transaction data for all accounts linked to our study allows us to test for these possibilities and verify the quality of the survey data.

We also received personnel data from the partner firms. While these outcomes are not the focus of our analysis, we report a summary of treatment effects in Appendix Table D.12.

\subsection{Main Outcomes of Interest}

The focus of our study is the impact of payroll accounts on account use, consumer learning, and consumer protection. To measure how actively consumers engage with the account, we use both the self-reported survey data and the administrative transaction-level data. Intuitively, we would expect to see more active engagement with accounts under the payroll accounts treatment, as workers in this treatment condition receive direct deposit wage payments into their account by default and thus face much stronger incentives to actively engage with the account than workers in the bank or mobile account condition, for whom use of the account is optional.

make withdrawals.

${ }^{32}$ This masks differences in trust between types of accounts. Trust in bank accounts is generally higher than trust in mobile accounts. This may be due to customers not thinking of mobile accounts as a savings device, or customers being less inclined to trust commissions-motivated mobile money agents through which they access the account. 
We use two key outcomes to track how consumers learn to navigate the financial technology. Our first outcome, outside transactions, is an indicator for whether a transaction was performed outside the workplace. As Figure 2 illustrates, most employees in our sample report being either "uncomfortable" or "very uncomfortable" using a bank or mobile money agent without assistance. In the implementation of the study, we ensured that workers assigned to receive an account always had access to a bank or mobile money representative who could assist with problems accessing the account and resolve any technical issues. Such assistance was not available outside the workplace, which makes outside transactions a meaningful indicator of having learned to navigate the financial technology sufficiently to use it without assistance.

Our second outcome of interest is an indicator for performing a financial transaction through one's account rather than an intermediary. We focus on send-money transactions which, in our setting, only occur in mobile money accounts and are particularly relevant because of their potential use as a low-cost means of sending remittances. Making a send-money or payment transaction requires the customer to navigate the English language mobile money interface, enter their PIN, the transaction amount (inclusive or exclusive of cash-out fees), and the recipient's phone number. This opens up many possibilities for error, so the norm is for inexperienced consumers to perform sendmoney transactions through a mobile agent who typically charges between 2-6\% of the transaction amount for providing this service in addition to any fees charged by the mobile money provider. ${ }^{33}$ These added fees are formally prohibited by the mobile money platform, but are commonplace. We thus measure learning using the outcome variable direct transactions, which measures to what extent customers learn to make transactions directly through their own account, thereby sidestepping intermediaries and avoiding illicit fees altogether. This is the key indicator for evaluating any consumer protection benefits of payroll accounts and learning.

While not our main focus, we can also measure whether payroll accounts affect other real outcomes of interest, including total savings, remittances sent to friends and family, consumption, and the ability to smooth shocks.

\subsection{Balance and Attrition}

Table 1, columns (2) to (4) present tests of balance and confirms that the randomization was successful. The tests show that the treatment groups are balanced along pre-treatment observables.

Given the high rates of worker turnover we observe in our setting, one potential concern is the possibility of differential attrition by treatment. ${ }^{34}$ In order to reduce the overall level of attrition, we collected additional contact data for all study participants and complemented field surveys with

\footnotetext{
${ }^{33}$ In our setting, send-money transactions are free of charge. The recipient is charged a fee of $1.9 \%$ of the transaction amount only when cashing out.

${ }^{34}$ If workers thought the payroll account was a useful perk, treatment could reduce turnover. On the other hand, if workers were better able to meet their savings goals in treatment arms in which they received an account, treatment could hasten turnover.
} 
phone interviews of workers that either left the factory after the initial treatment assignment or couldn't be reached in-person. Table 2 tests for differential survey attrition and worker turnover. The results show that there is no indication of differential attrition or worker turnover by treatment. While the absence of differential attrition is reassuring, we can also validate a subset of our survey results with administrative data, which contains transaction-level information on the full universe of program accounts over time.

\section{Empirical Strategy and Results}

Treatment was randomly assigned at the individual level, so that we can estimate the impact of payroll accounts using simple treatment effect regressions of the form:

$$
Y_{i}=\alpha+\gamma_{a c c t} T_{i, \text { acct }}+\gamma_{\text {payroll }} T_{i, \text { payroll }}+X^{\prime} \delta+\epsilon_{i}
$$

where $Y_{i}$ is an outcome of interest measured post-treatment, $T_{i, a c c t}$ is a treatment indicator equal to one if an individual was assigned to the bank or mobile account treatment and $T_{i, p a y r o l l}$ is a treatment indicator equal to one if individual $i$ was assigned to the bank or mobile payroll account treatment condition. ${ }^{35} X$ is a vector of controls which, where we use survey data includes the value of the outcome variable at baseline $Y_{i}^{B L}$ as well as strata dummies, and $\epsilon_{i}$ is a stochastic error term. In this specification, the coefficient $\gamma_{\text {payroll }}$ measures the impact of payroll accounts with direct deposit wage payments.

Where we use administrative data rather than survey outcomes to estimate treatment effects we use regressions where the treatment indicators $T_{i t, a c c t}$ and $T_{i t, p a y r o l l}$ are zero in the periods before the randomly-assigned account opening date and equal to one thereafter. This means that in these specifications, the treatment effects are estimated relative to a control group whose outcomes are zero by construction. Because we do not observe transactions for the control group, the comparison of interest in these specifications is between $\gamma_{\text {payroll }}$ and $\gamma_{\text {account }}$, the treatment effect estimates for the payroll account, compared to the account only treatment groups, respectively.

\subsection{Account Use and Learning}

In this section, we examine the effect of payroll accounts on account use and learning. The main interest of our study is to understand whether consistent use of a formal account enables inexperienced consumers to learn how to navigate the financial technology more effectively and avoid common consumer protection risks. Examining this question requires variation on the extensive margin of account ownership as well as the intensive margin of how frequently the account is used. Our experiment is designed to generate variation along both dimensions by separately randomizing

\footnotetext{
${ }^{35}$ We pool the bank and mobile money account treatments and provide disaggregated results in Appendix D.1.
} 
access to an account and automatic wage payments into the account. We begin our analysis by outlining patterns of account usage over time to confirm that the payroll account treatment was indeed successful at encouraging active engagement with the account, over and above the effect of account opening alone.

Account use. Figure 3 shows patterns of account use over time for the payroll account and account only groups for the first six months post treatment. ${ }^{36}$ The figure is based on administrative data, so that there is no scope for interviewer demand effects. The figure reveals that employees assigned to the payroll account treatment use their account more actively than employees assigned to the account only treatment group. Figure 3, panels (a) to (c) show that they make more withdrawals, more deposits, and more send-money transactions. ${ }^{37}$ The observation that employees in the payroll account group use their account more frequently overall (Figure 3, panel (d)) is in part mechanical, given that workers in this group receive their wages into the account and make withdrawals to cover daily expenses. In Figure 3, panel (e) we therefore exclude withdrawals and show that employees in the payroll account treatment condition use their account much more actively, even when we consider only deposit, payment, and send-money transactions. ${ }^{38}$

Table 3, reports treatment effects on account use. The dataset we use for this exercise is a panel that records the universe of transactions for all participants who received an account as part of our study. Because administrative data is not available for the control group, and we are most interested in a comparison of the payroll account and account only groups, our analysis uses the fact that treatment date was staggered over time and randomized at the individual level. We define a time-varying treatment indicator for each account in the data that is equal to zero prior to account opening and equal to one thereafter. This allows us to estimate treatment effects for the payroll account and account groups. Table 4, panel A uses dummy variables for all outcomes, so that the treatment effect estimates can be interpreted as the share of workers in each treatment condition that made a given type of transaction. we account for multiple hypothesis testing by reporting sharpened q-values in brackets in Table 3 and subsequently (Anderson, 2008). Sharpened q-values are calculated within data source, that is, separately for administrative and survey data.

The results in Table 3, columns (1) to (6) confirm that engagement with the account is significantly higher for workers in the payroll accounts group, who received an account with monthly direct deposit wage payments. Workers in the payroll account group are 59 percentage points to make a transaction through their account $(\mathrm{p}$-value=0.000). In a given month, workers in the payroll account group are 58 percentage points more likely to make a withdrawal from their account $(\mathrm{p}$-value $=0.000)$, only one percentage point more likely to make a deposit ( $\mathrm{p}$-value $=0.171)$, and

\footnotetext{
${ }^{36}$ Note that account opening occurred in several phases and was staggered over time, so that the figure shows months since account opening, rather than calendar months.

${ }^{37}$ In our setting, sending remittances through the conventional banking system is prohibitively expensive, so that the send-money and payment transactions in our data are all made using mobile money accounts.

${ }^{38}$ The size of these effects naturally differs between bank and mobile money accounts. We report descriptive statistics by type of account in the appendix.
} 
27 percentage points more likely to make a send-money transaction ( $\mathrm{p}$-value $=0.000$ ) than workers in the account only treatment condition. In Table 3, column (5) we report total transactions excluding withdrawals to ensure that the higher overall engagement with the account in the payroll account group is not simply result of workers mechanically having to withdraw their salary. The results show that this is not the case. In a given month, workers in the payroll account group are 12.8 percentage points as likely to make a non-withdrawal transaction than workers in the account only treatment group ( $\mathrm{p}$-value $=0.000$ ). Workers in the payroll account condition also accumulate balances that are, on average, BDT 334 (approximately $7 \%$ of the median monthly wage) higher than those of workers in the account only group ( $\mathrm{p}$-value $=0.000$ ).

Overall, these patterns indicate that our main treatment encouraged active account use, and suggests that active engagement helps inexperienced consumers to not only become sufficiently comfortable with the technology to perform an increasing number of transactions but also to accumulate formal savings in their accounts.

Learning. We next turn to the effect of payroll accounts on learning. We measure learning using the two outcome variables described in Section 3.3, above. Our first learning outcomes is an indicator for whether a transaction was performed outside the workplace, where assistance with the account was not readily available. We measure this outcome in administrative data, which records the precise geographical location of each transaction and allows us to identify whether a transaction took place at banking and mobile money facilities outside the study location.

Figure 4 shows the share of respondents that made at least one transaction at a bank or mobile money facility outside the study site at endline. The figure shows that, unconditionally, participants in the payroll accounts group who interacted with the account more frequently were 58 percentage points more likely to make a transaction in a setting without assistance than participants in the bank or mobile account only group.

Table 4, panel A reports the corresponding regression results and reports results for different types of outside transactions. We use the same panel and specification as in Table 3 for this exercise, so that treatment effects can be interpreted as the average post-treatment likelihood of making an outside transaction for workers in the payroll and account only treatment conditions.

Table 4, columns (1) to (3) show that workers assigned to the payroll account treatment quickly become confident enough to make a significant share of their transactions at locations outside the workplace. They are 21 percentage points more likely to make a withdrawal (p-value=0.000), 27 percentage points more likely to make a send-money transaction ( $\mathrm{p}$-value $=0.000$ ), but not more likely to make a deposit outside the workplace ( $\mathrm{p}$-value=0.197). In Table 4, column (5) we again verify that the higher number of outside transactions is not explained mechanically by withdrawals in the payroll account treatment group alone. The results show that this is not the case. When we exclude withdrawals, we find that workers in the treatment group are still 12 percentage points more likely to make a transaction outside the workplace than workers in the account group. This suggests 
that workers who use their account more actively learn to navigate the technology more quickly and become sufficiently comfortable with the account to also use it in settings where assistance is not as readily available as at the banking facilities in the workplace.

One possible concern with this interpretation is that the increase in outside transactions we observe in the payroll account group might be the result of banking facilities not being available at times when employees need to access their account, rather than the result of learning. To test this potential alternative explanation, Appendix Table D.13 repeats the estimates in Table 4, panel A, columns (1) to (6), but excludes any transactions that occurred on weekends. Appendix Table D.14 repeats the exercise and additionally excludes transactions that occurred outside work hours. The results are similar in all three samples, which suggests that the increase in outside transactions occurs by choice rather than as a result of banking facilities and mobile agents at the workplace being unavailable when workers in the payroll account group need to access their account.

Our second learning outcome is an indicator for whether send-money transactions are made directly through a study participant's own account, rather than a mobile money agent. Learning to make transactions through one's account directly eliminates various consumer protection risks, including illicit fees and service charges which are widespread in our context and many similar settings. We examine treatment effects on direct versus indirect transactions using primarily data from the endline survey. This has the advantage of allowing us to observe both direct and indirect transactions (indirect transactions are typically routed through a mobile agent's account on behalf of the customer, so that we do not observe them in administrative data). ${ }^{39}$ In our analysis, we use a dummy variable equal to one if a participant made at least one send-money transaction directly from their account.

Figure 5 shows unconditional means for direct and indirect transactions at endline. Figure 5 , panel (a) reports the share of workers who made at least one send-money transaction directly from their account (direct transactions) for the bank or mobile account and bank or mobile payroll treatment groups. Figure 5, panel (b) reports the share of workers who make at least one sendmoney transaction that is intermediated by a mobile money agent for the bank or mobile account and bank or mobile payroll treatment groups, respectively. The figure illustrates that, at endline, workers in the payroll account treatment condition are significantly more likely to make direct transactions. They are 42 percentage points more likely to make send-money transactions through their own account than workers in the account only group (p-value $<0.001)$ and that, at the same time, they are 32 percentage points less likely to make transactions that are intermediated by a mobile money agent ( $\mathrm{p}$-value $<0.001)$.

Table 4, panel B reports treatment effect estimates on direct versus intermediated transactions. For this exercise, we use survey data, which - unlike administrative data- also allows us to observe

\footnotetext{
${ }^{39}$ We report results using administrative data in the appendix for comparison and confirm that the results on direct transactions are consistent with estimates using self-reported data.
} 
changes in intermediated transactions that are made through a channel other than the respondent's own account. The results confirm that workers in the payroll account treatment condition reduce the share of transactions intermediated by an agent and learn how to transact through their own account. The results in columns (5) and (6) confirm that, at endline, study participants in the payroll account treatment condition are 32 percentage points less likely to make send-money transactions through an intermediary, and 42 percentage points more likely to make make send-money transactions through their own account than participants in the account only group ( $\mathrm{p}$-values=0.000).

In Table 4, panel B, columns (1) to (4) we examine intermediated and non-intermediated transactions by type of transaction. The results in columns(1) and (2) show that the decline in agentintermediated transactions arises from both a reduction in agent-to-agent transactions, which are 16 percentage points lower in the payroll account than in the accounts only group ( $\mathrm{p}$-value $=0.000$ ), as well as a reduction in agent-to-person transactions which, at endline, are 15 percentage points less common in the payroll accounts than in the account only group $(p=0.000)$. In columns (3) and (4) we see that at the increase in direct transactions in the payroll accounts group is larger for person-to-agent transfers, which are 32 percentage points more common in the payroll than in the account only group, than for person-to-person transactions with an approximate 23 percentage point difference. This is not surprising, given that remittance recipients are often located in rural areas where, at the time of our study, mobile money adoption was still comparatively low. Taken together, we interpret these results as evidence that workers who are incentivized to interact with an account more frequently as a result of receiving automatic wage payments become more confident using the financial technology and learn to use the account in the most cost-effective manner.

Since our estimates are based on a within-firm randomization, one might be concerned that our results - especially the estimated impacts on learning - could be obscured by peer effects. While any learning from peers would bias our treatment effects towards zero, we nonetheless examine this possibility to understand whether peer effects are at play in our setting. In Appendix Table D.9, we report results that additionally control for the size of each employee's network, measured as the number of employees employed in firm $k$ who come from the same sub-district (upazila) $s$ as employee $i, N e t w o r k_{-i}^{k, s}$, as well as the share of peers that are treated in each employee's network with either a payroll account Network treated payroll ${ }_{-i}^{k, s}$ or an account Network treated account ${ }_{-i}^{k, s}$. We do not find significant network effects, and our main results remain unchanged.

Trust in the Technology. To interpret the mechanisms through which our treatments lead to consumer learning, we examine the impact of payroll accounts on trust in the technology. In Table 5, we examine how the more frequent interaction with the financial technology, induced by the payroll account treatment affect trust in the technology. We measure trust, using a set of questions from the endline, in which respondents were asked how comfortable they would be to leave an amount of BDT 1,000 (US\$ 12) or BDT 5,000 (US\$ 60) in their account for a period of one month. Trust in formal accounts at baseline is low, and especially so in the case of mobile 
accounts: $55.6 \%$ of respondents would be comfortable leaving BDT 1,000 in a bank account for one month, while only $38 \%$ of respondents would be willing to leave the same amount in a mobile money account. The observation that consumers have lower trust in mobile money accounts is not surprising and likely due to several factors, including the technology being newer, less established, more complex to use, and more susceptible to consumer protection issues.

The results in Table 5, summarized in Figure 6, show that the payroll account treatment increases trust in the technology, particularly so in the case of mobile money accounts. While the treatment effects are positive for both the bank payroll and bank account only treatments, relative to control, the effects are not statistically significant. ${ }^{40}$ Moreover, the impacts are not detectably different between the payroll and account only groups. In contrast, the mobile payroll accounts are particularly effective at increasing trust. Receiving a simple mobile account increases trust in leaving 1,000 BDT by 8.2 percentage points (p-value 0.036 ), an increase of $22 \%$ relative to the control mean. The payroll account treatment has an even larger effect, increasing trust in the account by 16.8 percentage points ( $\mathrm{p}$-value 0.031 ), an increase $44 \%$ relative to control. We can also reject equality of the payroll and account only treatments. Receiving a payroll account almost completely eliminates the trust gap between mobile money and bank accounts. Against the background of the learning results, our preferred interpretation of this finding is that active engagement with a formal account promoted by the payroll account treatment causes customers to learn how to use the technology in a more effective and cost-saving manner. This, in turn allows them to sidestep common financial consumer protection risks, such as illicit transaction fees, and generates greater trust in the financial technology. It is not surprising that this effect is larger in the case of mobile money accounts for which baseline trust is lower, consumer protection risks are more severe, and the scope for learning about the features of the technology is greater.

\subsection{Real Effects: Savings, Consumption, and Shock-Mitigation}

In this section, we report the impact of payroll accounts on real outcomes. While the main interest of our study is on how inexperienced individuals learn to use the financial technology, we also measure the extent to which engagement with accounts affects real outcomes, such as total savings, consumption, and the ability to cope with unanticipated economic shocks. Our analysis of real effects relies mainly on survey data, which allows us to capture a richer set of outcomes than administrative data alone. We report results for all outcomes that are available in administrative and survey data in the appendix and show that the results are consistent.

Savings. In Table 6, we examine the effect of payroll accounts on savings, remittances, and shock-mitigation. Panel A shows results based on endline survey data only, panel B reports results

\footnotetext{
${ }^{40}$ We note that between baseline and endline, trust in both technologies in the control group increased substantially. This may be due to the increased prevalence of formal accounts in Dhaka or because of spillovers from the treatments onto the control group. In the presence of spillovers, the coefficients would be underestimates.
} 
from the combined panel of follow-up and endline surveys. The results in column (1) reveal that the payroll account treatment had a strong positive effect on the extensive margin of savings and increased the share of participants who reported having any savings by approximately 4 percentage points at endline and 11 percentage points when we use the full panel of midline and endline surveys. This effect is statistically different from the account only condition in both datasets (p-values 0.036 and 0.007), which confirms that the direct deposit feature is helpful at encouraging new savings. The results in Table 6, column (2) show that the payroll account treatment has an even larger effect on the intensive margin of savings. Participants in the payroll accounts group increased their savings by $51 \log$ points at endline and $89 \log$ points when we consider the full panel of followup and endline surveys. The effects are statistically different for the bank or mobile payroll and bank or mobile account conditions in the endline sample (p-value 0.041) as well as in the panel of follow-up and endline surveys (p-value 0.084). This is consistent with previous work on the effect of account ownership and suggests that, although direct deposits provide an additional commitment device that promotes savings, simply being given an account can help increase savings. In Table 6, columns (3) and (4) we turn to the impact of payroll accounts on the share of formal versus informal savings and find that, as one would expect, our treatments reduce the share of informal savings and an increase in the share of formal savings. These effects are again concentrated in the payroll account group (p-value 0.000 in both samples). ${ }^{41}$

In column (5) we report treatment effects on remittances. A priori, the potential impact of payroll accounts on remittances is ambiguous in our setting. In addition to supporting the consumption of network members back home, workers also use remittances to save. ${ }^{42}$ Savings held by friends and family may be subject to problems of control, as documented for example by Jakiela and Ozier (2015).As we have shown above, when used correctly, formal accounts reduce the cost of sending remittances, which should lead to an increase in transfers. However, formal accounts also lower the relative cost of private savings. This force would lead payroll accounts to decrease remittances. We find no evidence that payroll accounts increase remittances. Moreover, while the point estimate is negative, it is not statistically significant. ${ }^{43}$ Our finding that remittances do not increase shows that improvements in learning cannot be explained by an increased demand for remittance services.

\footnotetext{
${ }^{41}$ In Appendix D.1, we further decompose these impacts by bank and mobile account. Both account types offer a similar interest rate for deposits and encourage savings, though the impacts are larger in bank payroll accounts. The impacts on remittances are similar by account type. Finally, the impacts on consumption and shock-mitigation are also comparable. While workers save more in their bank accounts, mobile recipients experience an increase in incoming transfers, both of which may help to mitigate shocks.

${ }^{42}$ Because many workers do not have a safe or convenient place to save in the city, many ask family members in their place of origin to save on their behalf, either in their homes or in a rural bank account.

${ }^{43}$ We note that our findings contrast with those of Lee et al. (2020), who show that giving simple mobile money accounts to both the senders and recipients of remittances in Bangladesh causes a large increase in remittances. Treating both parties may cause a larger total decrease in the cost of sending money than our treatment, and it also may give the remittance recipients more bargaining power over migrant earnings. This latter interpretation is consistent with the decreases in migrant health and well-being they document.
} 
Consumption. Table 6, columns (6) to (10) turn to the impact of payroll accounts on consumption. In Table 6, column (6) we report treatment effects on total consumption, columns (7) and (8) show disaggregated effects for food and non-food consumption. The results, while not statistically distinguishable between the payroll account and account treatment groups, suggest that participants the payroll accounts group are able to mobilize new savings by reducing consumption. When we disaggregate the results by type of consumption, we find that this reduction in expenditures is concentrated entirely in discretionary spending, while food consumption remains constant. In column (9), we additionally consider larger purchases of more than BDT 1,000 (approximately $20 \%$ of the median monthly wage). The results indicate a statistically significant decrease in such larger purchases for our treatment group relative to the cash wage payments control group. However, we cannot statistically distinguish the treatment effects between the payroll account and account groups (p-values 0.561 and 0.966).

Shock mitigation. Summary statistics from our baseline survey highlight the fact that many workers face savings constraints and find it difficult to smooth consumption across the month. ${ }^{44}$ Given that direct deposits increase savings and appear to decrease spending on discretionary goods, it is natural to ask whether they also help workers smooth consumption and mitigate large financial shocks. In Table 6, column (10) we consider the impact of payroll accounts on the ability to mitigate unanticipated income shocks. The results indicate that participants in the payroll accounts treatment group experience significantly fewer economic shocks that they are unable to mitigate with existing precautionary savings. However, we cannot distinguish the effect in the payroll account group from that of the account only group. We report additional results on mechanisms for smoothing consumption in Appendix Table D.12, which reports treatment effects on earnings and work satisfaction. In line with the results on shock-mitigation we find that, at endline, workers in the payroll account group are much less reliant on salary advances to at the end of the month. This is consistent with the increase in precautionary savings and reduction in discretionary spending in the payroll account group that we have documented above.

Taken together, our results on the real effects of payroll accounts are consistent with the prior literature and suggest that through more intensive engagement with the financial technology, payroll accounts increase savings on the intensive and extensive margin and improve the ability to cope with unanticipated income shocks. These positive impacts may reflect greater availability of precautionary savings documented above. Another interpretation is that the use of mobile payments might facilitate the receipt of transfers as well as strengthen and expand informal insurance networks among poor households (Jack and Suri, 2014). This is somewhat less likely in our setting, as workers in large factories are generally net senders of remittances. However, we do find some evidence that payroll accounts increase likelihood of receiving money through the accounts.

\footnotetext{
${ }^{44}$ Nearly half of our sample needs to borrow to smooth consumption at the end of the month, $22 \%$ of our study participants report that they would not be able to save BDT 5,000 (approximately US\$ 60) over a six-month period.
} 


\subsection{Heterogeneity: Who Learns to Navigate the Technology?}

We document above that the introduction of payroll accounts increases account use and engagement and also leads to more efficient use of the new technology. However, from a regulatory perspective it is crucial to understand whether these consumer protection benefits are experienced broadly or whether certain subgroups are left behind. Our study population spans a heterogeneous set of individuals by gender, education, financial literacy, household composition and structure, control over household resources, and work experience. One might predict, ex ante, that any of these dimensions might lead to heterogeneous treatment effects. ${ }^{45}$ In order to test for treatment heterogeneity in a disciplined way, we implement the recently-developed methodology of Chernozhukov et al. (2018). We are especially interested to examine whether there is predictable heterogeneity in the two main findings reported above: (i) "learning by doing" and efficient use of the account (ii) expanding savings by cutting discretionary spending.

Methodology. To proceed, we follow the method and road map laid out by Chernozhukov et al. (2018). Namely, we consider an environment in which we want to learn about the conditional average treatment effect (CATE):

$$
s_{0}(Z):=E[Y(1) \mid Z]-E[Y(0) \mid Z]
$$

$Y(1)$ and $Y(0)$ are the potential outcomes under the treatment and $Z$ is a vector of covariates. The method laid out by Chernozhukov et al. (2018) uses machine learning (ML) proxies $S(Z)$ for the CATE, $s_{0}(Z)$, and provides a method to conduct inferences on different features of the underlying heterogeneous treatment effects. ${ }^{46}$ In addition to providing an estimate of the heterogeneous treatment effect, Chernozhukov et al. (2018) demonstrate how to construct two additional features of the data. First, the authors show how to estimate group average treatment effects (GATES), which gives measures of the treatment effects separately for the most and least impacted groups. Following Chernozhukov et al. (2018), we consider the highest and lowest quintile groups in our GATES analyses. Second, once the GATES have been constructed, Chernozhukov et al. (2018) show how to conduct a classification analysis (CLAN), which gives the average characteristics $Z$ of the most and least affected groups. We follow these steps to ask if there is any detectable heterogeneity in our observed treatment effects as a function of 17 baseline characteristics. ${ }^{47}$

\footnotetext{
${ }^{45}$ These are all listed as potential sources of heterogeneity in the outline of our study in the AEA RCT registry.

${ }^{46}$ All of our estimates employ a Random Forest algorithm in the ML step.

${ }^{47} \mathrm{We}$ use the following set of baseline characteristics: gender, marital status, indicator for parent, education, indicator for literate in the local language, digit span test score, the fraction of income shared with others, control over food expenditures within the household, an indicator for strictly positive savings, an indicator for positive formal savings, an indicator for being able to save BDT 5,000, an indicator for sending remittances in a typical month, an indicator for having prior experience with mobile transactions, and indicator for needing to borrow to pay for basic consumption at the end of the month, number of years in current job, and expected tenure in current job.
} 
Results. We consider heterogeneous treatment effects for our key outcomes. Table 7 presents a GATES analysis, comparing the most affected quintile with the least affected quintile, by baseline characteristics. Panel A includes the main savings and consumption outcomes and pools across the bank and mobile direct deposit treatments relative to the control group. Panel B includes the main "learning-by-doing" outcomes. Because these outcomes mostly involve mobile account usage patterns, here we only consider the mobile direct deposit treatment versus the control. ${ }^{48}$ Across most outcomes, we find no detectable heterogeneity in the treatment effects. This suggests that treatment gains, where we find them, tend to be spread evenly across the population. However, we do detect heterogeneity in two important dimensions: consumption as well as our key learning outcomes. Recall that a decrease in consumption is indicative of new savings, rather than a reallocation across formal and informal accounts. Total transactions indicate the level of worker engagement with their accounts, and direct transactions indicate efficient usage of the mobile technology, avoiding illicit fees, an outcome of direct relevance for consumer protection.

Finally, in Table 8, we present a CLAN analysis to better understand which individual traits are associated with the largest impacts on new savings and learning. The first column pertains to the heterogeneity with respect to the effects on total consumption, while columns (2) to (4) pertain to the learning impacts - total transactions, outside transactions, and direct transactions. ${ }^{49}$ Interestingly, we find that the results split our sample into "savers" and "learners" - the traits that are correlated with a large, negative consumption response are often the same traits that predict a smaller learning response and vice versa. Females, and workers with low baseline control over expenditures, low levels of savings, and low levels of prior financial experience are more likely to be classified in the group which has the largest decline in consumption. This implies that the treatment enables new savings out of consumption for those individuals who were previously most severely excluded from the formal financial system either through gender norms, spousal sharing restrictions, basic access, or knowledge. In contrast, men, non-parents, workers with more education, and workers with higher levels of savings, or baseline financial inclusion are more likely to be classified into the group with the largest "learning-by-doing" treatment responses. This suggests that learning-by-doing is most effective for those who have some prior exposure to financial products and higher ex ante levels of financial control and literacy.

Taken together, the results suggests that the treatments have two different sets of impacts on the "savers" and "learners." For those with previously low levels of financial inclusion, the treatments give households access to a safe, convenient, and individually-controlled place to save, which leads treated workers to decrease consumption in order to fund savings. However, learning by doing may not be enough for these individuals to solve important consumer protection problems on their own. More far-reaching interventions may be needed.

\footnotetext{
${ }^{48}$ Appendix Table D.15 presents the CATE analysis for the same set of outcomes.

${ }^{49}$ Note that the most affected group is the one with the largest absolute treatment effect. In the case of consumption, the least affected group is that with the most negative consumption response.
} 
In contrast, for those with higher baseline rates of financial inclusion, the treatment does not change the extensive margin of consumption versus savings, but does encourage workers to engage more deeply with the new technology. For these workers, engagement with the account has large impacts on avoiding illicit transaction fees, indicating substantial consumer protection gains from learning through active use of accounts.

\section{Externalities from Consumer Learning}

In this section, we explore the possible market-level externalities of consumer learning. Our results so far show that the introduction of payroll accounts has positive impacts on learning and real outcomes on average, but also highlights that these benefits are concentrated among consumers with comparatively higher baseline levels of financial literacy and experience. Less experienced consumers who might depend on the help of peers or commission motivated agents to use the technology, on the other hand, remain exposed to numerous consumer protection risks. In light of these results, an interesting question is whether inexperienced customers benefit from the average customer becoming more informed as a result of the financial technology being rolled out at scale.

We examine this question using a separate audit study that takes advantage of local variation in the extent of payroll account adoption. In the audit study, workers were trained to approach mobile money agents located in areas with different levels of payroll account adoption and ask for assistance with a simple remittance transaction. The workers were trained on two scripts: a low skill script that signaled very limited prior experience with the technology and a high skill script which indicated that the worker was an experienced user of the technology, who had previously used their own account to send and receive money. ${ }^{50}$

We conducted the audit study in a suburban area surrounding our main study site, which is one of the largest industrial areas in the country. We divided this area into 24 roughly equalsized zones with each zone corresponding to a self-contained neighborhood, and obtained data on total employment, number of manufacturing firms, and number of firms that had adopted payroll accounts in each neighborhood. ${ }^{51}$ We use this information to calculate payroll account penetration for each neighborhood and assign each auditor to attempt an equal proportion of transactions in neighborhoods with high (above median) and low (below median) payroll account adoption. In total, auditors attempted 504 transactions over a six-month period, of which 154 (31\%) were successful in the sense that the transaction was completed and the full amount was remitted to the recipient. The outcome of interest is whether the sender was charged a fee in addition to the recipient cash-out charge, which is a practice explicitly prohibited by the mobile money provider.

The results suggest that there are positive externalities from the widespread adoption of digital

\footnotetext{
${ }^{50}$ The scripts used in the audit study are available in the appendix.

${ }^{51}$ Data were obtained from the national industry association and verified by survey staff on the ground.
} 
payroll accounts. Figure 7 plots unconditional means for the frequency of illicit transaction fees in high and low payroll account adoption areas and shows that, unconditionally, workers are 16 percentage points less likely to be charged an illicit fee in areas with high payroll account adoption. Table 9 reports treatment effect estimates that control for auditor fixed effects. The results from this exercise, reported in column (1), show that the same worker is 15 percentage points more likely to be charged an illicit fee when attempting a transaction in a neighborhood with low payroll account adoption. The results in column (2) show that workers who signal a lack of experience with the mobile account are 44 percentage points more likely to be charged an illicit transaction fee than workers who are experienced users. However, the effect of being inexperienced is much more pronounced in areas with low payroll account adoption. The results in column (4) indicate that inexperienced customers were approximately 12 percentage points more likely to be charged an illicit fee in areas with low payroll account adoption.

There are two possible explanations for this result. The lower probability of uninformed workers being overcharged in areas with high payroll penetration could be a positive spillover of widespread technology adoption, with mobile agents becoming more cautious about charging extra fees as the average consumer becomes better informed. Alternatively, a lower incidence of consumers being overcharged could also be the result of greater competition between mobile agents. While it is beyond the scope of our study to exogenously vary the intensity of competition between mobile agents, we can partly address this concern by controlling for the number and density of mobile agents in each neighborhood. We report the results from this exercise in Appendix Table D.16, where we control for the density of mobile agents directly, and show that the results remain unchanged. We therefore interpret our results as suggestive evidence that the widespread adoption of payroll accounts generates a positive externality by reducing information asymmetries at the market level and decreasing the likelihood of mobile agents extracting rents from uninformed consumers.

\section{Conclusion}

Over the last two decades, an unprecedented expansion in access to finance has presented households around the world with an ever-widening set of new financial products and technologies. While this has given consumers greater choice and autonomy, it has also given rise to public policy concerns in light of growing evidence that inexperienced consumers are especially susceptible to exploitation by financial intermediaries.

We conducted an experiment to understand how much learning occurs naturally, and in the absence of any regulatory intervention, when a new financial technology is rolled out to an inexperienced customer population. We introduced payroll accounts - a simple financial technology that generates a powerful incentive to actively engage with a formal account - to a population of largely unbanked manufacturing workers in Bangladesh and examined how quickly individuals learn to use 
the account without assistance and avoid ubiquitous consumer protection risks.

We find compelling evidence of learning-by-doing. Workers in the payroll account treatment condition interact with the account more frequently, develop greater trust in the technology, learn to use the account without assistance, and learn how to avoid common consumer financial risks and use the account in the most cost-effective way. This is not mechanical, as we made it easy for treated individuals to replicate the status quo wage disbursements with their payroll accounts. Receiving wages into a payroll account benefits employees through this learning channel, as well as its impact on real outcomes including an increase in savings on the extensive and intensive margin and the improved ability to mitigate unanticipated shocks.

The benefits of engaging with the financial technology are not evenly distributed in the population. Results from a data-driven machine learning analysis of treatment effect heterogeneity neatly partition our sample into a population of "savers" and a population of "learners". Individuals with comparatively lower literacy, financial experience, and prior control over household finances benefit from exposure to the technology primarily from accumulating savings but do not necessarily learn to use the financial technology in the most cost-effective manner. Individuals with higher levels of literacy, financial experience, and prior control over household finances, on the other hand, benefit by learning to use the technology more effectively and sidestepping common consumer protection risks. We additionally examine the impact of introducing the financial technology at scale and find suggestive evidence of positive market externalities of consumer learning: inexperienced customers are less likely to face extra charges in areas with higher payroll account adoption. This result should, however, be interpreted with caution, since it is beyond the scope of this study to exogenously vary supply-side factors, such as the degree of local competition between mobile agents.

Our results speak to a larger debate on the optimal targeting of financial consumer protection policies. While we show that there is a substantial amount of learning that occurs naturally, through trial and error, we are cautious to note that these learning benefits are present only for a subset of our population. Looking at the individual characteristics that determine who can benefit from learning-by-doing, our results suggest that training and education interventions would have the highest marginal effect on individuals with low baseline levels of literacy, experience, and prior control over household finances. All of these characteristics are highly correlated with accessing one's account through an intermediary, which precludes learning-by-doing.

Our findings also lend support to policies that promote consumer learning through automatic payments into an account. We find that channeling wage payments into an account creates a strong incentive to engage with the account and learn about the features of the technology in a way that is not achieved by account opening alone. Indeed, automatic payments into an account are now the default for many government transfer payments (see, for example, Muralidharan et al. 2016 and Bachas et al. 2017). Channeling wage payments into formal accounts is an obvious next step with potentially large positive implications for access to finance and consumer learning in low and 
middle-income countries where wage payments are still made predominantly in cash.

One remaining question, given the benefits of payroll accounts and the costs of cash, is why the market has not stepped in to expand the availability of payroll accounts at scale. While we note that payroll accounts have expanded rapidly since our intervention, our results also point to several barriers that could be at play. First, employers may fear resistance from employees due to a lack of trust in the technology. Indeed our results document very low levels of trust at baseline, which improve as consumers interact with the technology on a regular basis. Second, an important barrier to scale-up may be insufficient documentation. In our setting we found that many workers did not have sufficient documentation and had to rely on identification and guarantees provided by their employer to open an account. Third, some employers may want to avoid the transparency that comes with payroll accounts and may require nudges from regulators to adopt payroll accounts. 


\section{References}

Agarwal, Sumit, Sashwat Alok, Pulak Ghosh, Soumya Kanti Ghosh, Tomasz Piskorski, and Amit Seru, "Banking the Unbanked: What do 255 Million New Bank Accounts Reveal about Financial Access," Working Paper, 2018.

_, Souphala Chomsisengphet, Neale Mahoney, and Johannes Stroebel, "Regulating Consumer Financial Products," Quarterly Journal of Economics, 2015, 130 (1), 111-164.

Aker, Jenny C, Silvia Prina, and C Jamilah Welch, "Migration, Money Transfers, and Mobile Money: Evidence from Niger," in "AEA Papers and Proceedings," Vol. 110 2020, pp. 589-93.

Anagol, Santosh, Shawn Cole, and Shayak Sarkar, "Understanding the Advice of Commissions-Motivated Agents: Evidence from the Indian Life Insurance Market," Review of Economics and Statistics, 2017, 99 (1), 1-15.

_, Vimal Balasubramaniam, and Tarun Ramadorai, "Learning from Noise: Evidence from Indias IPO Lotteries," Journal of Financial Economics, 2020.

Anderson, Michael L., "Multiple Inference and Gender Differences in the Effects of Early Intervention: A Reevaluation of the Abecedarian, Perry Preschool, and Early Training Projects," Journal of the American statistical Association, 2008, 103 (484), 1481-1495.

Annan, Francis, "Gender and Financial Misconduct: a Field Experiment on Mobile Money," Working Paper, 2019.

Bachas, Pierre, Paul Gertler, Sean Higgins, and Enrique Seira, "How Debit Cards Enable the Poor to Save More," NBER Working Paper 23252, 2017.

Badarinza, Cristian, Vimal Balasubramaniam, and Tarun Ramadorai, "The Household Finance Landscape in Emerging Economies," Annual Review of Financial Economics, 2019.

Batista, Catia, Pedro C Vicente et al., "Is Mobile Money Changing Rural Africa? Evidence from a Field Experiment," Working Paper, 2018.

Bertrand, Marianne and Adair Morse, "Information Disclosure, Cognitive Biases and Payday Borrowing," Journal of Finance, 2011, pp. 1865-1893.

Beshears, John, James J. Choi, Christopher Harris, David Laibson, Brigitte C. Madrian, and Jung Sakong, "Which Early Withdrawal Penalty Attracts the Most Deposits to a Commitment Savings Account?," Journal of Public Economics, 2020, 183.

_ , _, David Laibson, and Brigitte C. Madrian, "Behavioral Household Finance," in Douglas Bernheim, ed., Handbook of Behavioral Economics: Foundations and Applications, Vol. 1, Amsterdam: Elsevier, 2018, chapter 3, pp. 177-276.

Blumenstock, Joshua, Michael Callen, and Tarek Ghani, "Why Do Defaults Affect Behavior? Experimental Evidence from Afghanistan," American Economic Review, October 2018, 108 (10), 2868-2901. 
Boudreau, Laura, "Multinational Enforcement of Labor Law: Experimental Evidence from Bangladeshs Apparel Sector," Working Paper, 2020.

Breza, Emily and Arun G. Chandrasekhar, "Social Networks, Reputation, and Commitment: Evidence From a Savings Monitors Experiment," Econometrica, 2019, 87 (1), 175-216.

_, Martin Kanz, and Leora Klapper, "Workplace Signaling and Financial Commitment: Evidence from a Field Experiment," American Economic Association Papers and Proceedings, 2018, 108, 438-443.

Brown, James R., J Anthony Cookson, and Rawley Heimer, "Growing Up without Finance," Journal of Financial Economics, 2019, 134 (3), 591-616.

Bruhn, Miriam and Inessa Love, "The Real Impact of Improved Access to Finance: Evidence from Mexico," The Journal of Finance, 2014, 69, 1347-1376.

Burgess, Robin and Rohini Pande, "Do Rural Banks Matter? Evidence from the Indian Social Banking Experiment," American Economic Review, June 2005, 95 (3), 780-795.

Callen, Michael, Suresh De Mel, Craig McIntosh, and Christopher Woodruff, "What Are the Headwaters of Formal Savings? Experimental Evidence from Sri Lanka," Review of Economic Studies, 2019.

Campbell, John Y., E. Jackson Howell, Brigitte Madrian, and Peter Tufano, "Consumer Financial Protection," Journal of Economic Perspectives, 2011, 25 (1), 91-114.

Carlin, Bruce, Arna Olafsson, and Michaela Pagel, "Fintech Adoption Across Generations: Financial Fitness in the Information Age," National Bureau of Economic Research Working Paper, 2017.

Chernozhukov, Victor, Mert Demirer, Esther Duflo, and Ivan Fernandez-Val, "Generic Machine Learning Inference on Heterogenous Treatment Effects in Randomized Experiments," Technical Report, National Bureau of Economic Research 2018.

Demirgüç-Kunt, Asli, Leora Klapper, Dorothé Singer, and Peter van Oudheusden, "Measuring Financial Inclusion and Opportunities to Expand Access to and Use of Financial Services," World Bank Economic Review, 2017, 31.

Dobbie, Will and Paige Martha Skiba, "Information Asymmetries in Consumer Credit Markets: Evidence from Payday Lending," American Economic Journal: Applied Economics, 2013, $5(4), 256-282$.

Dupas, Pascaline and Jonathan Robinson, "Why Don't the Poor Save More? Evidence from Health Savings Experiments," American Economic Review, 2013, 103 (4), 1138-71.

Egan, Mark, Gregor Matvos, and Amit Seru, "The Market for Financial Adviser Misconduct," Journal of Political Economy, 2019, 127 (1), 233-295.

Field, Erica, Rohini Pande, Natalia Rigol, Simone Schaner, and Charity Troyer Moore, "On Her Own Account: How Strengthening Womens Financial Control Impacts Labor Supply and Gender Norms," Working Paper, 2018. 
Gabaix, Xavier and David Laibson, "Shrouded Attributes, Consumer Myopia, and Information Suppression in Financial Markets," Quarterly Journal of Economics, 2006, 121 (2), 505-540.

Giné, Xavier and Jessica Goldberg, "Status Quo Bias and Usage of Financial Products: Field Evidence from Malawi," Working Paper, 2020.

_, Cristina Martinez, and Rafael Mazer, "Financial (Dis-) Information: Evidence from an Audit Study in Mexico," World Bank Policy Research Working Paper, 2014, (6902).

_, _, and _, "Information Disclosure and Demand Elasticity of Financial Products: Evidence from a Multi-Country Study," Working Paper, 2017.

Haushofer, Johannes and Jeremy Shapiro, "The Short-Term Impact of Unconditional Cash Transfers to the Poor: Experimental Evidence from Kenya," Quarterly Journal of Economics, 2016, 131 (4), 1973-2042.

Heath, Rachel and A. Mushfiq Mobarak, "Manufacturing Growth and the Lives of Bangladeshi Women," Journal of Development Economics, 2015, 115 (2).

Jack, William and Tavneet Suri, "Risk Sharing and Transactions Costs: Evidence from Kenya's Mobile Money Revolution," American Economic Review, January 2014, 104 (1), 183-223.

_ and _ , "The Long-Run Poverty and Gender Impacts of Mobile Money," Science, 2016, 354 (6317), 1288-1292.

Jakiela, Pamela and Owen Ozier, "Does Africa Need a Rotten Kin Theorem? Experimental Evidence from Village Economies," The Review of Economic Studies, 09 2015, 83 (1), 231-268.

Kremer, Michael, "The O-Ring Theory of Economic Development," Quarterly Journal of Economics, August 1993, 108 (3), 551-575.

Lee, Jean N., Jonathan Morduch, Saravana Ravindran, Abu S. Shonchoy, and Hassan Zaman, "Poverty and Migration in the Digital Age: Experimental Evidence on Mobile Banking in Bangladesh," American Economic Journal: Applied Economics, 2020.

Machiavello, Rocco, Andreas Menzel, Atonu Rabbani, and Christopher Woodruff, "Challenges of Change: An Experiment Training Women to Manage in the Bangladeshi Garment Sector," Working Paper, 2020.

_, Julia Cajal-Grossi, and Guillermo Noguera, "International Buyers' Sourcing and Suppliers' Markups in Bangladeshi Garments," Working Paper, 2020.

Madrian, Brigitte C. and Dennis F. Shea, "The Power of Suggestion: Inertia in 401(k) Participation and Savings Behavior," The Quarterly Journal of Economics, 2001, 116 (4), 11491187.

Mullainathan, Sendhil, Michael Barr, and Eldar Shafir, "The Case for Behaviorally Informed Regulation," in David Moss and John Cisternino, eds., New Perspectives on Regulation, Cambridge, MA: The Tobin Project, 2009, chapter 2, pp. 25-62. 
Muralidharan, Karthik, Paul Niehaus, and Sandip Sukhtankar, "Building State Capacity: Evidence from Biometric Smartcards in India," American Economic Review, October 2016, 106 (10), 2895-2929.

Riley, Emma, "Resisting Social Pressure in the Household Using Mobile Money: Experimental Evidence on Microenterprise Investment in Uganda," University of Oxford, May, 2020, 25.

Schaner, Simone, "The Persistent Power of Behavioral Change: Long-run Impacts of Temporary Savings Subsidies for the Poor," American Economic Journal: Applied Economics, 2018, 10 (3), $67-100$.

Somville, Vincent and Lore Vandewalle, "Saving by Default: Evidence from a Field Experiment in Rural India," American Economic Journal: Applied Economics, 2018, 10 (3), 39-66.

Suri, Tavneet, "Mobile Money," Annual Review of Economics, 2017, 9 (1), 497-520.

World Bank, "Global Findex Database," 2017. https://globalfindex.worldbank.org. 


\section{Figures and Tables}

Figure 1

\section{Trust in Formal Accounts}

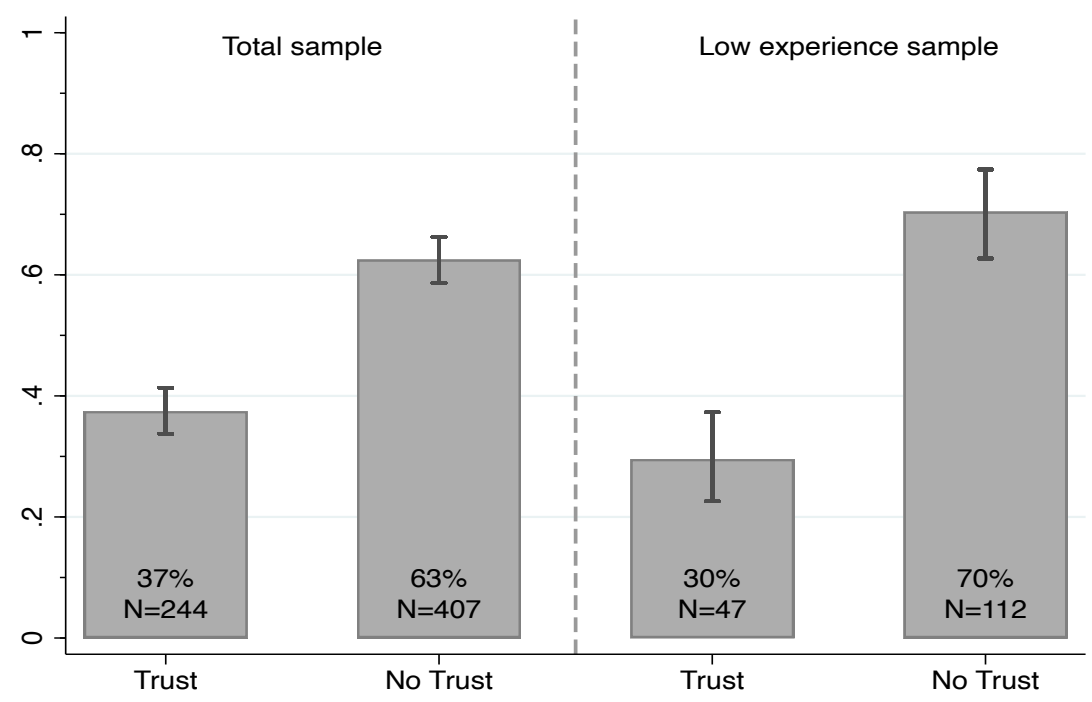

Notes: The figure shows unconditional means and 95\% confidence intervals for self-reported trust in formal accounts for the control group $(\mathrm{N}=728)$. The trust variables are calculated using responses to: "would you be comfortable leaving BDT 1,000 in a [bank or mobile] account for 30 days?" Answers are reported on a 10-point scale. We first average responses across bank or mobile. "Trust" is defined as an indicator for whether this average trust score is $>5$. Panel (a) shows trust for the entire sample, panel (b) shows trust for workers with low prior exposure to formal accounts, defined as having never used a bank or mobile money account. 
Figure 2

Confidence Using Formal Accounts

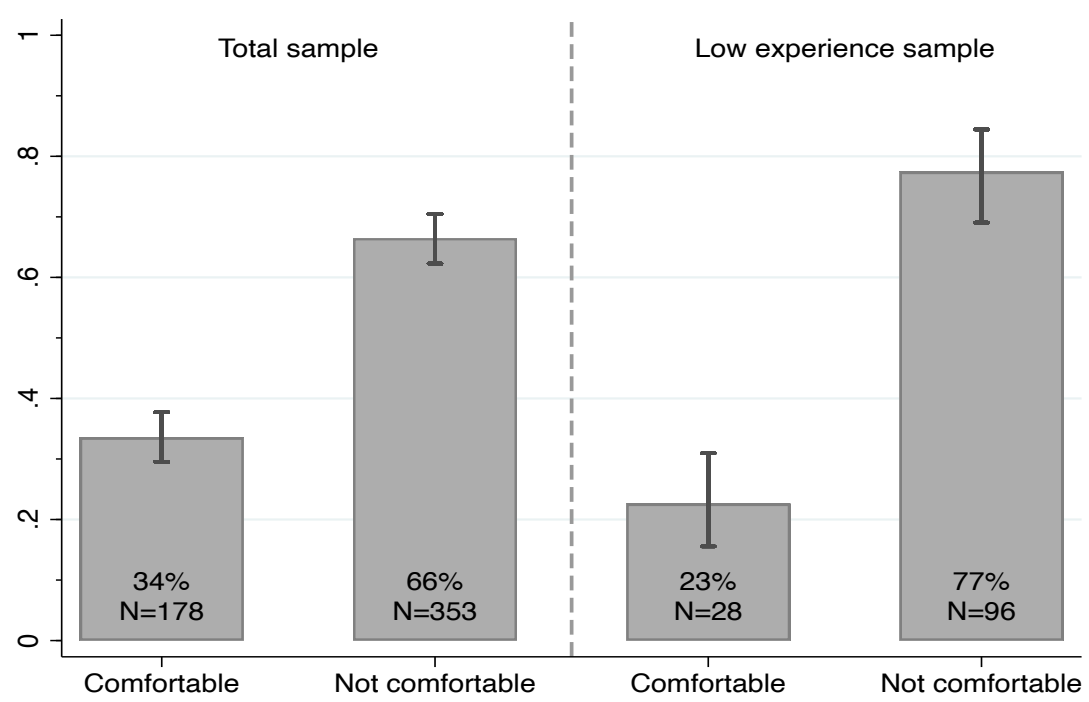

Notes: The figure shows unconditional means and 95\% confidence intervals of participants' self-reported level of confidence using bank branches or mobile money agents $(\mathrm{N}=534)$. Panel (a) shows responses for the entire sample, panel (b) shows responses for workers with low prior exposure to formal accounts, defined as having never used a bank or mobile money account. The figure is based on responses to the survey question "how comfortable are you making a transaction at a bank branch or mobile money agent". 
Figure 3

Transactions Over Time

(a) Deposits

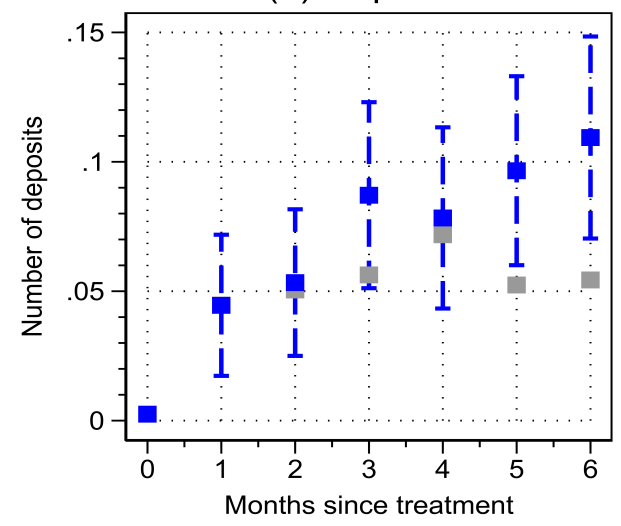

(d) Transactions

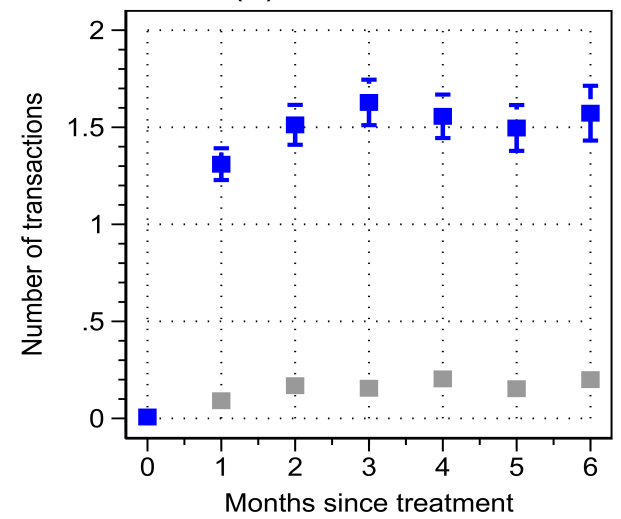

(b) Withdrawals

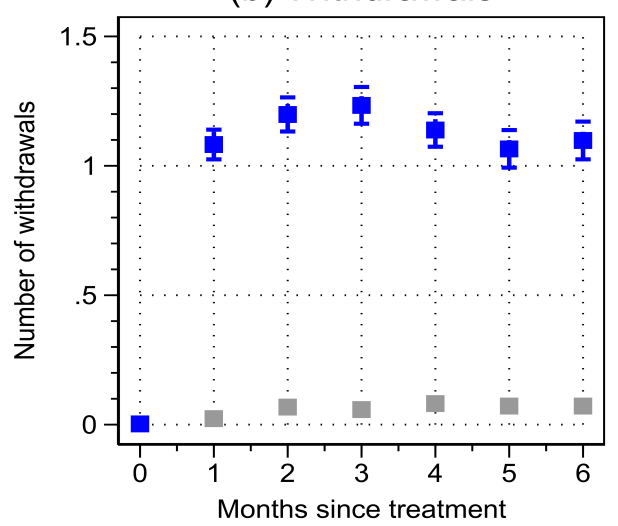

(e) Excluding withdrawals

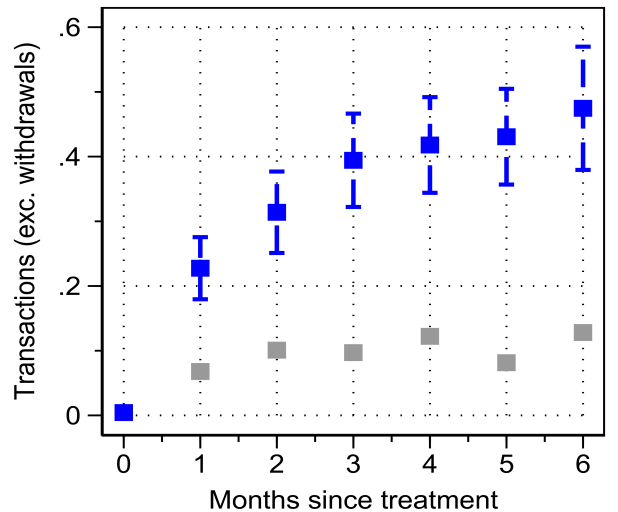

(c) Send-money

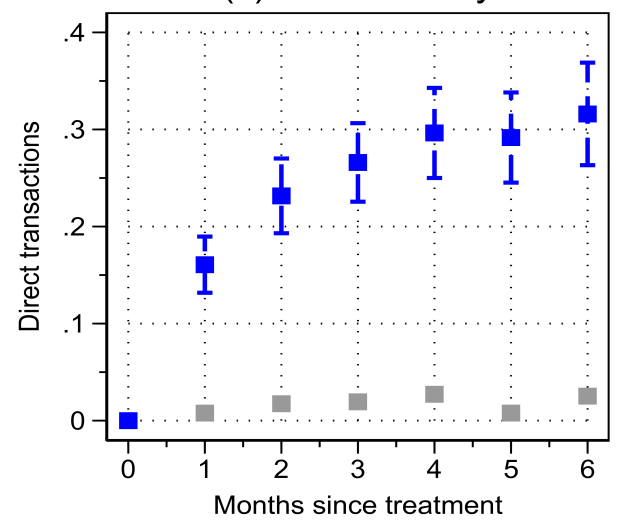

(f) Balance

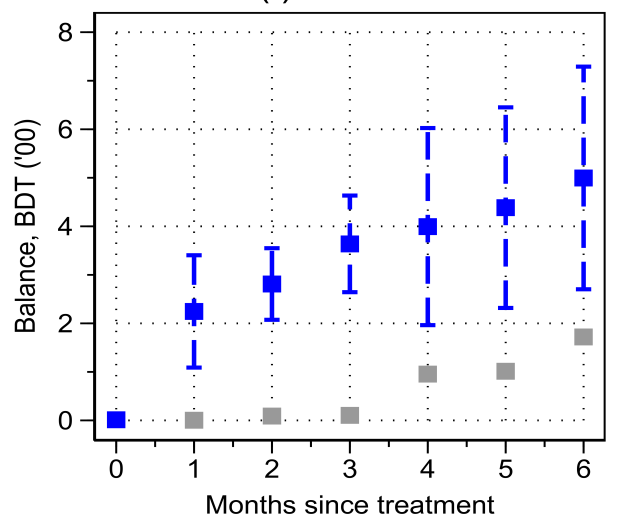

Bank or mobile account

Bank or mobile payroll

Notes: The figure shows monthly averages of transactions and account use over time for the bank or mobile payroll and bank or mobile account treatment groups, based on administrative data for the first six months post treatment. Panel (a) shows the number of deposits, panel (b) shows the number of withdrawals, panel (c) shows the number of send-money transactions, panel (d) plots the number of total transactions, panel (e) plots the number of total monthly transactions excluding withdrawals, and panel (f) plots monthly account balances. Error bars show $95 \%$ confidence intervals for a test of equality between the treatments. 
Figure 4

Learning: Transactions without Assistance

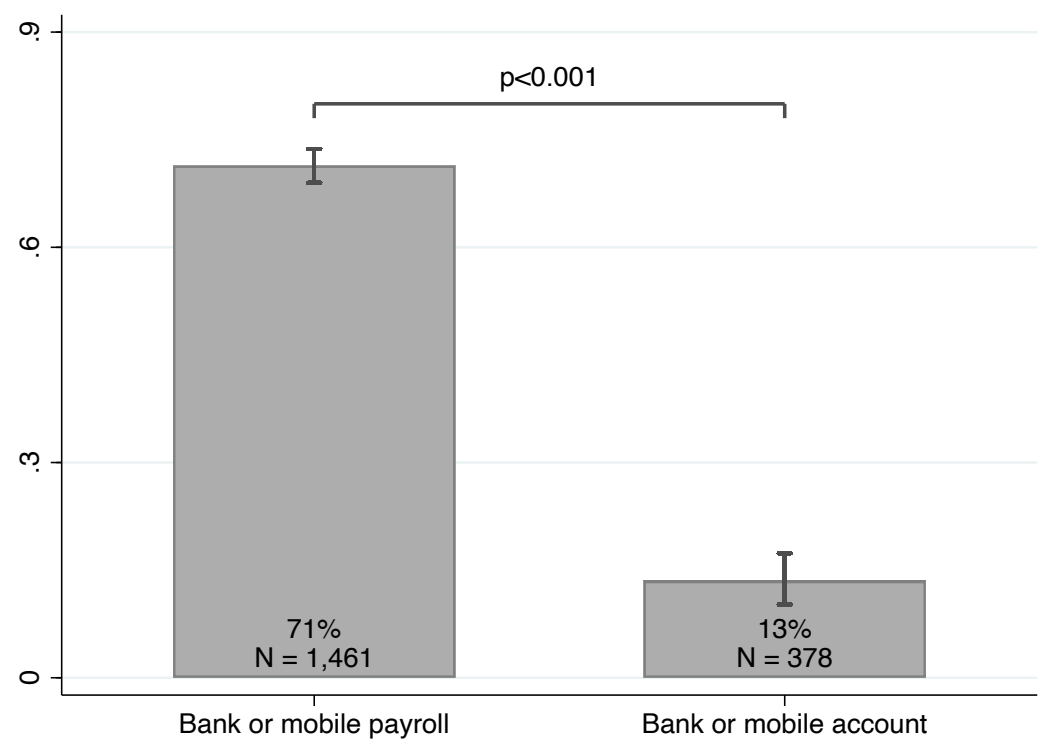

Notes: The figure displays the share of respondents that made at least one transaction at a banking or mobile money facility outside the study location by treatment, measured in administrative data at endline. Error bars show 95\% confidence intervals of the mean. Horizontal bars show p-values for $t$-tests of equality between the treatment conditions. 
Figure 5

\section{Learning: Direct versus Indirect Transactions}

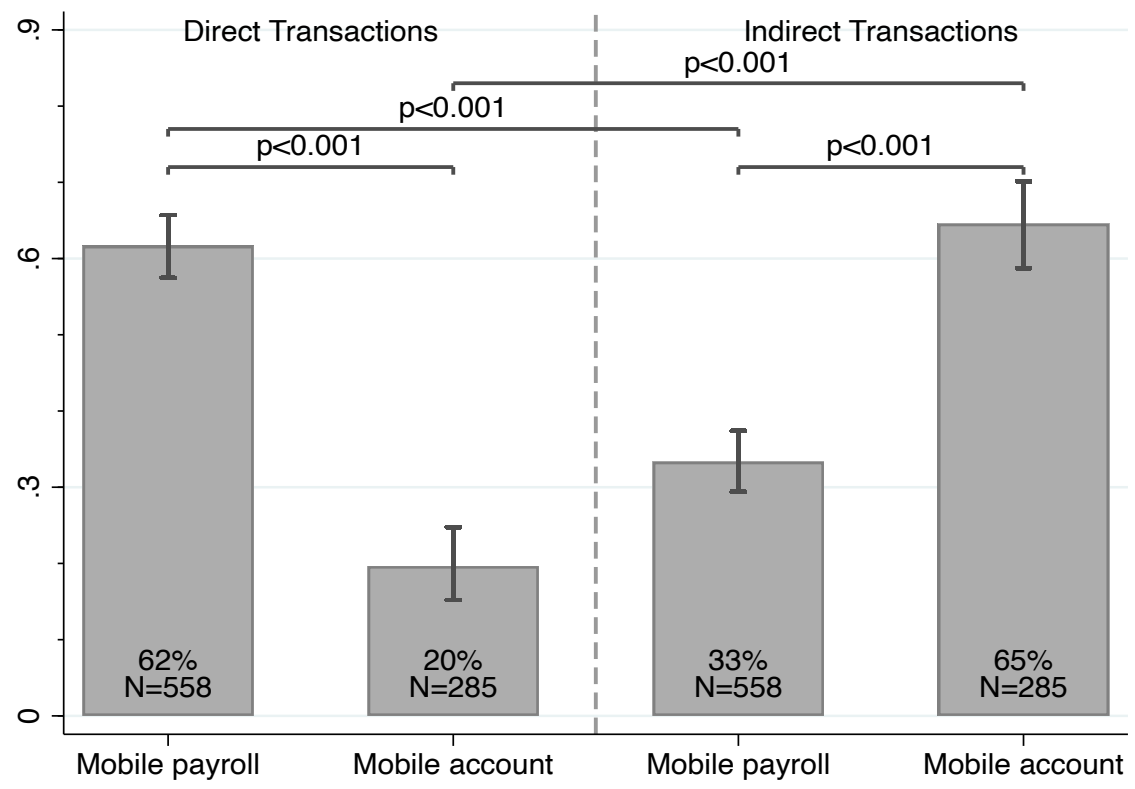

Notes: The figure shows the percentage of respondents making direct versus indirect sendmoney transactions by treatment, measured in survey data at endline. Panel (a) displays the share of respondents who made at least one send-money transaction from their own account for the mobile payroll account and mobile account groups. For reference, the mean of the control group is $12 \%$, which is statistically distinguishable from both the mobile payroll and mobile account treatments. Panel (b) displays the share of respondents who made at least one send-money transaction intermediated by a mobile agent for the mobile payroll account and mobile account groups. For reference, the mean of the control group is $61 \%$, which is statistically distinguishable from the mobile payroll treatment only. Error bars show 95\% confidence intervals of the mean. Horizontal bars show p-values for $t$-tests of equality between the treatment conditions. 
Figure 6

Trust in the Technology

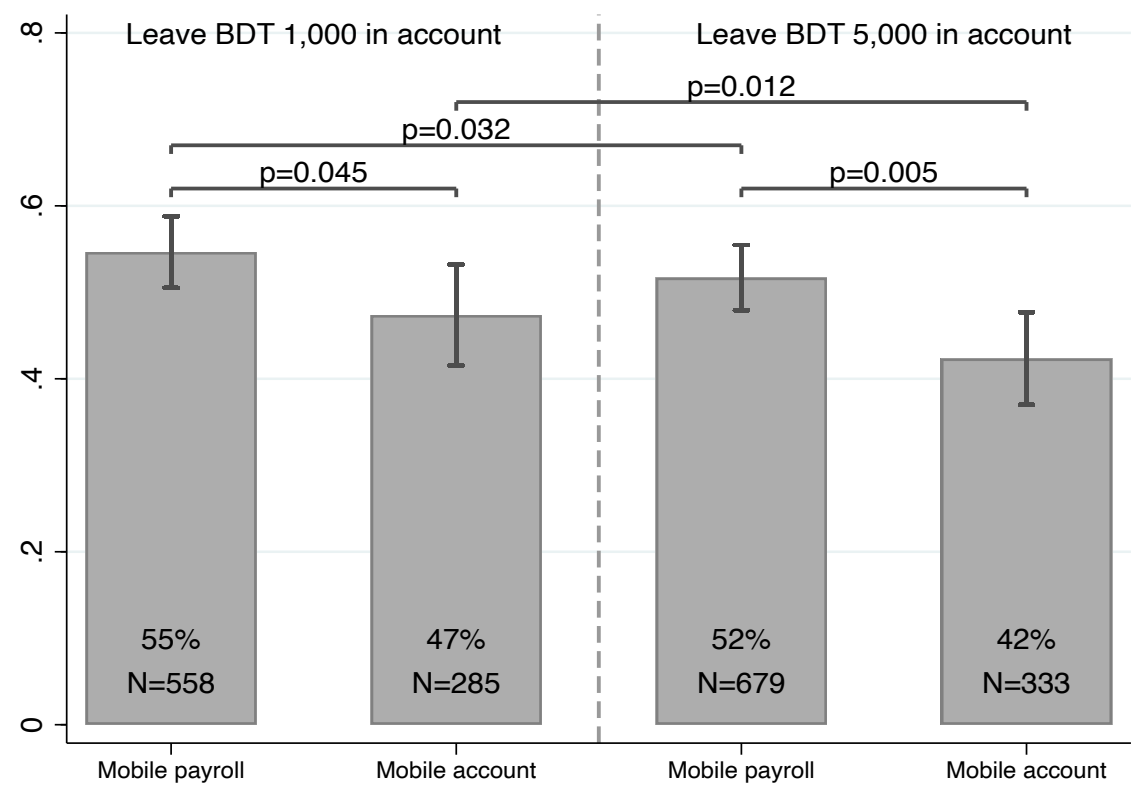

Notes: Panel (a) displays the share of participants that feel "comfortable" or "very comfortable" leaving BDT 1,000 and BDT 5,000 in their account for the mobile payroll group, based on data from the endline survey. Panel (b) shows the share of participants who feel "very comfortable" or "absolutely comfortable" leaving BDT 1,000 and BDT 5,000 in their account for the mobile accounts group, based on data from the endline survey. For reference, the mean of the control group is $38 \%$ for both the BDT 1,000 BDT 5,000 questions. Error bars show $95 \%$ confidence intervals of the mean. Horizontal bars show p-values for $t$-tests of equality of means between the different treatment conditions. 
Figure 7

Externalities of Payroll Account Adoption

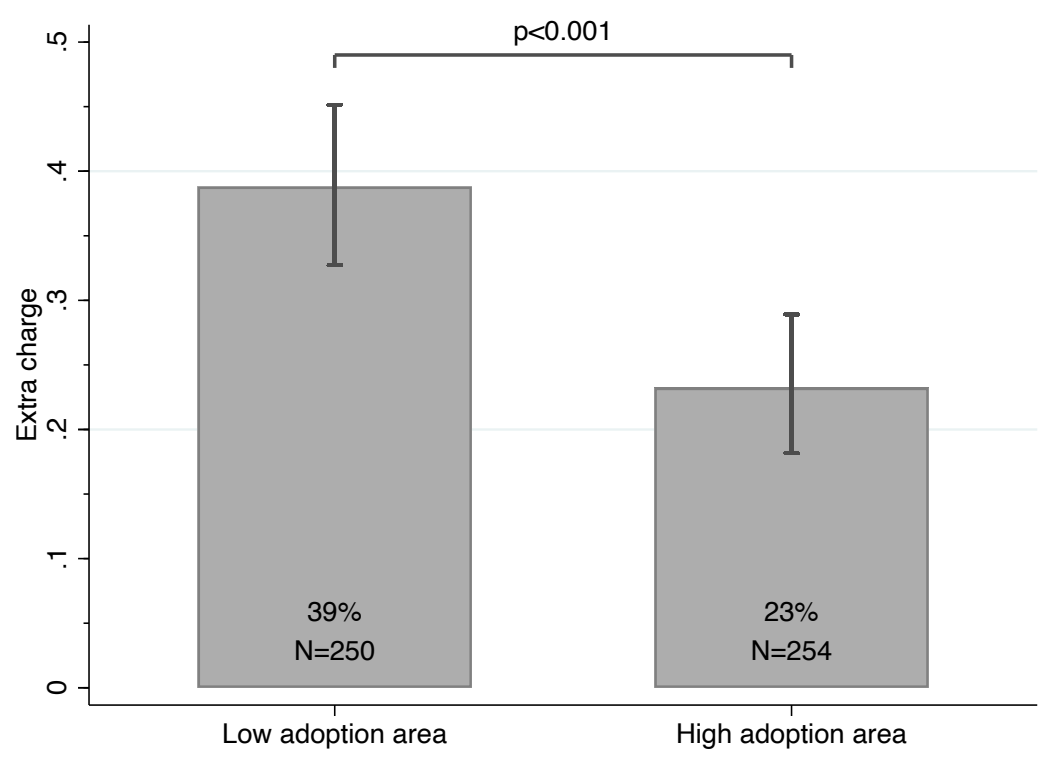

Notes: The figure displays the percentage of audit visits on which auditors were charged

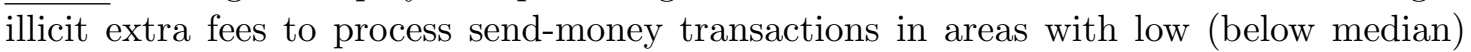
and high (above median) payroll account adoption. The sample is split by the number of firms in the area that have adopted payroll accounts. Error bars show $95 \%$ confidence intervals of the mean. Horizontal bars show p-values for a $t$-test of equality of means. 
Table 1 Summary Statistics and Balance

\begin{tabular}{|c|c|c|c|c|}
\hline & \multicolumn{4}{|c|}{ Treatment } \\
\hline & $\begin{array}{c}\text { Control } \\
(1)\end{array}$ & $\begin{array}{c}\text { Payroll } \\
\text { - control } \\
(2)\end{array}$ & $\begin{array}{c}\text { Account } \\
\text { - control } \\
(3)\end{array}$ & $\begin{array}{c}\text { Payroll } \\
\text { - account } \\
(4)\end{array}$ \\
\hline & \multicolumn{4}{|c|}{ Panel A: demographics } \\
\hline Female & $\begin{array}{c}0.576 \\
(0.019)\end{array}$ & $\begin{array}{c}0.011 \\
(0.023)\end{array}$ & $\begin{array}{c}0.005 \\
(0.028)\end{array}$ & $\begin{array}{c}0.006 \\
(0.024)\end{array}$ \\
\hline Married & $\begin{array}{c}0.720 \\
(0.018)\end{array}$ & $\begin{array}{l}-0.003 \\
(0.021)\end{array}$ & $\begin{array}{l}-0.004 \\
(0.026)\end{array}$ & $\begin{array}{c}0.001 \\
(0.022)\end{array}$ \\
\hline Dependent children & $\begin{array}{c}0.565 \\
(0.019)\end{array}$ & $\begin{array}{c}0.018 \\
(0.023)\end{array}$ & $\begin{array}{c}0.014 \\
(0.028)\end{array}$ & $\begin{array}{c}0.004 \\
(0.024)\end{array}$ \\
\hline Education & $\begin{array}{c}3.289 \\
(0.059)\end{array}$ & $\begin{array}{c}0.066 \\
(0.070)\end{array}$ & $\begin{array}{c}0.217 \\
(0.091)\end{array}$ & $\begin{array}{l}-0.151 \\
(0.078)\end{array}$ \\
\hline Literate & $\begin{array}{c}0.573 \\
(0.019)\end{array}$ & $\begin{array}{c}0.028 \\
(0.023)\end{array}$ & $\begin{array}{c}0.067 \\
(0.028)\end{array}$ & $\begin{array}{l}-0.039 \\
(0.023)\end{array}$ \\
\hline Digit span score & $\begin{array}{c}5.143 \\
(0.048)\end{array}$ & $\begin{array}{l}-0.050 \\
(0.057)\end{array}$ & $\begin{array}{c}0.029 \\
(0.068)\end{array}$ & $\begin{array}{c}-0.078 \\
(0.057)\end{array}$ \\
\hline Monthly wage, taka & $\begin{array}{c}6778.743 \\
(59.029)\end{array}$ & $\begin{array}{l}139.119 \\
(73.771)\end{array}$ & $\begin{array}{c}65.944 \\
(94.019)\end{array}$ & $\begin{array}{c}73.174 \\
(85.515)\end{array}$ \\
\hline Work experience, years & $\begin{array}{c}3.840 \\
(0.166)\end{array}$ & $\begin{array}{c}-0.078 \\
(0.183)\end{array}$ & $\begin{array}{c}-0.394 \\
(0.182)\end{array}$ & $\begin{array}{c}0.316 \\
(0.108)\end{array}$ \\
\hline Experience in current job, years & $\begin{array}{c}3.055 \\
(0.077)\end{array}$ & $\begin{array}{l}-0.056 \\
(0.090)\end{array}$ & $\begin{array}{c}-0.420 \\
(0.104)\end{array}$ & $\begin{array}{c}0.364 \\
(0.085)\end{array}$ \\
\hline \multirow[t]{2}{*}{ Expected tenure in current job, years } & $\begin{array}{c}4.364 \\
(0.475) \\
\end{array}$ & $\begin{array}{l}-0.375 \\
(0.576) \\
\end{array}$ & $\begin{array}{l}-0.967 \\
(0.654)\end{array}$ & $\begin{array}{c}0.592 \\
(0.555) \\
\end{array}$ \\
\hline & \multicolumn{4}{|c|}{ Panel B: financial experience and planning } \\
\hline Ever used bank account & $\begin{array}{c}0.054 \\
(0.009)\end{array}$ & $\begin{array}{l}-0.008 \\
(0.010)\end{array}$ & $\begin{array}{c}0.006 \\
(0.013)\end{array}$ & $\begin{array}{l}-0.014 \\
(0.011)\end{array}$ \\
\hline Ever used mobile money & $\begin{array}{c}0.770 \\
(0.017)\end{array}$ & $\begin{array}{l}-0.002 \\
(0.020)\end{array}$ & $\begin{array}{c}0.006 \\
(0.024)\end{array}$ & $\begin{array}{l}-0.008 \\
(0.020)\end{array}$ \\
\hline Ever received mobile money & $\begin{array}{c}0.206 \\
(0.016)\end{array}$ & $\begin{array}{l}-0.002 \\
(0.019)\end{array}$ & $\begin{array}{c}0.049 \\
(0.024)\end{array}$ & $\begin{array}{l}-0.051 \\
(0.021)\end{array}$ \\
\hline Has balance in bank account & $\begin{array}{c}0.054 \\
(0.009)\end{array}$ & $\begin{array}{l}-0.008 \\
(0.010)\end{array}$ & $\begin{array}{c}0.006 \\
(0.013)\end{array}$ & $\begin{array}{l}-0.014 \\
(0.011)\end{array}$ \\
\hline Has balance in mobile money account & $\begin{array}{c}0.003 \\
(0.002)\end{array}$ & $\begin{array}{c}0.001 \\
(0.003)\end{array}$ & $\begin{array}{c}0.009 \\
(0.005)\end{array}$ & $\begin{array}{l}-0.008 \\
(0.005)\end{array}$ \\
\hline Basic expenditures control & $\begin{array}{c}0.469 \\
(0.020)\end{array}$ & $\begin{array}{c}0.013 \\
(0.023)\end{array}$ & $\begin{array}{l}-0.012 \\
(0.028)\end{array}$ & $\begin{array}{c}0.025 \\
(0.024)\end{array}$ \\
\hline \multirow[t]{2}{*}{ Income sharing } & $\begin{array}{c}0.462 \\
(0.020) \\
\end{array}$ & $\begin{array}{c}0.009 \\
(0.023) \\
\end{array}$ & $\begin{array}{c}-0.045 \\
(0.028) \\
\end{array}$ & $\begin{array}{c}0.054 \\
(0.024) \\
\end{array}$ \\
\hline & \multicolumn{4}{|c|}{ Panel C: savings and debt } \\
\hline Has savings & $\begin{array}{c}0.498 \\
(0.020)\end{array}$ & $\begin{array}{c}0.008 \\
(0.023)\end{array}$ & $\begin{array}{c}0.017 \\
(0.028)\end{array}$ & $\begin{array}{l}-0.009 \\
(0.024)\end{array}$ \\
\hline Has formal savings & 0.283 & -0.031 & -0.050 & 0.019 \\
\hline
\end{tabular}


Table 1: Summary Statistics and Balance (Continued)

\begin{tabular}{lcccc}
\hline \hline & $(0.018)$ & $(0.021)$ & $(0.025)$ & $(0.021)$ \\
Has informal savings & 0.215 & 0.039 & 0.067 & -0.028 \\
& $(0.016)$ & $(0.019)$ & $(0.025)$ & $(0.021)$ \\
Log total savings & 4.782 & -0.030 & 0.055 & -0.085 \\
& $(0.194)$ & $(0.229)$ & $(0.280)$ & $(0.237)$ \\
Log formal savings & 2.835 & -0.312 & -0.535 & 0.223 \\
& $(0.178)$ & $(0.208)$ & $(0.248)$ & $(0.204)$ \\
Log informal savings & 2.541 & 0.272 & 0.588 & -0.316 \\
& $(0.163)$ & $(0.195)$ & $(0.245)$ & $(0.212)$ \\
Has loans & 0.513 & 0.009 & -0.014 & 0.023 \\
& $(0.020)$ & $(0.023)$ & $(0.028)$ & $(0.024)$ \\
Has formal loans & 0.058 & -0.005 & -0.004 & -0.001 \\
& $(0.009)$ & $(0.011)$ & $(0.013)$ & $(0.011)$ \\
Has informal loans & 0.498 & -0.001 & -0.019 & 0.018 \\
& $(0.020)$ & $(0.023)$ & $(0.028)$ & $(0.024)$ \\
Log total loans & 4.447 & -0.019 & -0.177 & 0.158 \\
& $(0.174)$ & $(0.205)$ & $(0.251)$ & $(0.210)$ \\
Log formal loans & 0.093 & -0.041 & -0.044 & 0.003 \\
Log informal loans & $(0.038)$ & $(0.042)$ & $(0.047)$ & $(0.034)$ \\
Sent remittances & 4.244 & -0.100 & -0.215 & 0.115 \\
& $(0.171)$ & $(0.202)$ & $(0.246)$ & $(0.207)$ \\
Log remittances & 0.810 & -0.029 & -0.049 & 0.020 \\
& $(0.015)$ & $(0.019)$ & $(0.023)$ & $(0.020)$ \\
& 8.691 & -0.272 & -0.507 & 0.235 \\
& $(0.170)$ & $(0.205)$ & $(0.258)$ & $(0.225)$ \\
\hline Need to borrow & Panel & $\mathbf{D}:$ consumption smoothing \\
Able to save BDT 5,000 & 0.470 & 0.034 & 0.068 & -0.034 \\
& $(0.020)$ & $(0.023)$ & $(0.028)$ & $(0.024)$ \\
& 0.782 & -0.005 & 0.016 & -0.022 \\
& $(0.016)$ & $(0.019)$ & $(0.023)$ & $(0.020)$ \\
& 0.639 & 0.022 & 0.018 & 0.004 \\
& $(0.019)$ & $(0.022)$ & $(0.027)$ & $(0.023)$ \\
\hline
\end{tabular}

Notes: This table reports statistics for the baseline sample and tests of randomization balance

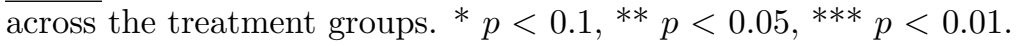


Table 2

Attrition by Treatment

\begin{tabular}{lcccc}
\hline \hline & \multicolumn{3}{c}{ Dependent variable: } \\
\cline { 2 - 5 } & $\begin{array}{c}\text { Surveyed } \\
(1)\end{array}$ & $\begin{array}{c}\text { Employed } \\
(2)\end{array}$ & $\begin{array}{c}\text { Surveyed } \\
(3)\end{array}$ & $\begin{array}{c}\text { Employed } \\
(4)\end{array}$ \\
\hline Bank or mobile payroll & -0.002 & -0.020 & -0.004 & -0.026 \\
& $(0.017)$ & $(0.021)$ & $(0.017)$ & $(0.021)$ \\
Bank or mobile account & -0.011 & -0.001 & -0.011 & -0.003 \\
& $(0.022)$ & $(0.026)$ & $(0.022)$ & $(0.026)$ \\
\hline Baseline controls & & & $\mathrm{X}$ & $\mathrm{X}$ \\
Observations & 2,850 & 2,850 & 2,850 & 2,850 \\
R-squared & 0.005 & 0.008 & 0.052 & 0.069 \\
Mean control [follow-up] & 0.840 & 0.719 & 0.840 & 0.719 \\
\hline
\end{tabular}

Notes: Tests for balanced attrition by treatment. The dependent variable in columns (1) and (3) is a dummy equal to 1 if a participant is in the data at the follow-up and end-line surveys, respectively. The dependent variable in columns (2) and (4) is a dummy equal to 1 if a participant was employed at the partner firm at the time of the follow-up and endline surveys, respectively. Controls include stratification dummies, marital status, number of dependents, dummies for savings, formal savings, years of work experience, and years with current employer. Robust standard errors in parentheses. Sharpened q-values in brackets. ${ }^{*} p<0.1,{ }^{* *} p<0.05,{ }^{* * *} p<0.01$. 
Table 3

Treatment Effects: Account Use

\begin{tabular}{|c|c|c|c|c|c|c|}
\hline & \multicolumn{6}{|c|}{ Dependent variable: } \\
\hline & $\begin{array}{l}\text { Deposits } \\
\quad(1)\end{array}$ & $\begin{array}{l}\text { Withdrawals } \\
(2)\end{array}$ & $\begin{array}{l}\text { Send-money } \\
\qquad(3)\end{array}$ & $\begin{array}{l}\text { Total } \\
(4)\end{array}$ & $\begin{array}{l}\text { Excl. withdrawals } \\
(5)\end{array}$ & $\begin{array}{l}\text { Balance } \\
\quad(6)\end{array}$ \\
\hline Bank or mobile payroll & $\begin{array}{c}0.060 * * * \\
(0.004) \\
{[0.001]}\end{array}$ & $\begin{array}{c}0.629^{* * *} \\
(0.008) \\
{[0.001]}\end{array}$ & $\begin{array}{c}0.292^{* * *} \\
(0.010) \\
{[0.001]}\end{array}$ & $\begin{array}{c}0.683^{* * *} \\
(0.008) \\
{[0.001]}\end{array}$ & $\begin{array}{c}0.200^{* * *} \\
(0.008) \\
{[0.001]}\end{array}$ & $\begin{array}{c}40.763^{* * *} \\
(47.377) \\
{[0.001]}\end{array}$ \\
\hline Bank or mobile account & $\begin{array}{c}0.050 * * * \\
(0.006) \\
{[0.001]}\end{array}$ & $\begin{array}{c}0.046^{* * *} \\
(0.006) \\
{[0.001]}\end{array}$ & $\begin{array}{c}0.021^{* * *} \\
(0.004) \\
{[0.001]}\end{array}$ & $\begin{array}{c}0.073^{* * *} \\
(0.009) \\
{[0.001]}\end{array}$ & $\begin{array}{c}0.072^{* * *} \\
(0.008) \\
{[0.001]}\end{array}$ & $\begin{array}{c}106.719^{* *} \\
(47.498) \\
{[0.003]}\end{array}$ \\
\hline $\begin{array}{l}\text { Test: payroll = account } \\
\text { Observations } \\
\text { R-squared }\end{array}$ & $\begin{array}{c}0.171 \\
40,458 \\
0.018\end{array}$ & $\begin{array}{c}0.000 \\
40,458 \\
0.454\end{array}$ & $\begin{array}{c}0.000 \\
24,046 \\
0.181\end{array}$ & $\begin{array}{c}0.000 \\
40,458 \\
0.492\end{array}$ & $\begin{array}{c}0.000 \\
40,458 \\
0.068\end{array}$ & $\begin{array}{c}0.000 \\
40,458 \\
0.011\end{array}$ \\
\hline
\end{tabular}

Notes: The table reports treatment effect estimates on account use, based on monthly administrative data. The dependent variable is a dummy equal to one if at least one transaction was recorded in a given calendar month. The omitted group consists of observations prior to random assignment to treatment, for which all outcomes are mechanically equal to zero. Regressions control for stratification dummies. Robust standard errors, clustered at the account level, in parentheses. Sharpened q-values in brackets. ${ }^{*} p<0.1,{ }^{* *} p<0.05,{ }^{* * *} p<0.01$. 
Table 4

Treatment Effects: Learning

\begin{tabular}{|c|c|c|c|c|c|c|}
\hline & \multicolumn{6}{|c|}{ Panel A: transactions outside the workplace } \\
\hline & \multicolumn{6}{|c|}{ Dependent variable: } \\
\hline & $\begin{array}{l}\text { Deposits } \\
\text { (1) }\end{array}$ & $\begin{array}{l}\text { Withdrawals } \\
(2)\end{array}$ & $\begin{array}{c}\text { Send-money } \\
(3)\end{array}$ & $\begin{array}{c}\text { Total } \\
(4)\end{array}$ & $\begin{array}{l}\text { Excl. withdrawals } \\
(5)\end{array}$ & $\begin{array}{l}\text { Balance } \\
(6)\end{array}$ \\
\hline Bank or mobile payroll & $\begin{array}{c}0.058 * * * \\
(0.004) \\
{[0.001]}\end{array}$ & $\begin{array}{c}0.260^{* * *} \\
(0.006) \\
{[0.001]}\end{array}$ & $\begin{array}{c}0.292^{* * *} \\
(0.010) \\
{[0.001]}\end{array}$ & $\begin{array}{c}0.353^{* * *} \\
(0.008) \\
{[0.001]}\end{array}$ & $\begin{array}{c}0.199^{* * *} \\
(0.008) \\
{[0.001]}\end{array}$ & $\begin{array}{c}440.763^{* * *} \\
(47.377) \\
{[0.001]}\end{array}$ \\
\hline Bank or mobile account & $\begin{array}{c}0.049^{* * * *} \\
(0.006) \\
{[0.001]}\end{array}$ & $\begin{array}{c}0.049^{* * *} \\
(0.005) \\
{[0.001]}\end{array}$ & $\begin{array}{c}0.021^{* * *} \\
(0.004) \\
{[0.001]}\end{array}$ & $\begin{array}{c}0.082^{* * *} \\
(0.008) \\
{[0.001]}\end{array}$ & $\begin{array}{c}0.072^{* * *} \\
(0.008) \\
{[0.001]}\end{array}$ & $\begin{array}{c}106.719^{* *} \\
(47.498) \\
{[0.003]}\end{array}$ \\
\hline $\begin{array}{l}\text { Test: } \text { payroll = account } \\
\text { Observations } \\
\text { R-squared }\end{array}$ & $\begin{array}{c}0.197 \\
40,458 \\
0.018\end{array}$ & $\begin{array}{c}0.000 \\
40,458 \\
0.113\end{array}$ & $\begin{array}{c}0.000 \\
24,046 \\
0.181\end{array}$ & $\begin{array}{c}0.000 \\
40,458 \\
0.150\end{array}$ & $\begin{array}{c}0.000 \\
40,458 \\
0.068\end{array}$ & $\begin{array}{c}0.000 \\
40,458 \\
0.011\end{array}$ \\
\hline \multirow{3}{*}{ R-squared } & \multicolumn{6}{|c|}{ Panel B: send money transactions } \\
\hline & \multicolumn{6}{|c|}{ Dependent variable: } \\
\hline & $\begin{array}{c}\text { Agent-to-agent } \\
\text { (1) }\end{array}$ & $\begin{array}{c}\text { Agent-to-person } \\
(2)\end{array}$ & $\begin{array}{c}\text { Person-to-agent } \\
(3)\end{array}$ & $\begin{array}{c}\text { Person-to-person } \\
(4)\end{array}$ & $\begin{array}{l}\text { Indirect } \\
(5)\end{array}$ & $\begin{array}{l}\text { Direct } \\
(6)\end{array}$ \\
\hline Mobile payroll & $\begin{array}{c}-0.194^{* * *} \\
(0.029) \\
{[0.001]}\end{array}$ & $\begin{array}{c}-0.061^{* *} \\
(0.026) \\
{[0.047]}\end{array}$ & $\begin{array}{c}0.362^{* * *} \\
(0.024) \\
{[0.001]}\end{array}$ & $\begin{array}{c}0.343^{* * *} \\
(0.023) \\
{[0.001]}\end{array}$ & $\begin{array}{c}-0.277^{* * *} \\
(0.030) \\
{[0.001]}\end{array}$ & $\begin{array}{c}0.494^{* * *} \\
(0.025) \\
{[0.001]}\end{array}$ \\
\hline Mobile account & $\begin{array}{l}-0.030 \\
(0.037) \\
{[0.260]}\end{array}$ & $\begin{array}{c}0.094^{* * *} \\
(0.034) \\
{[0.019]}\end{array}$ & $\begin{array}{c}0.038 \\
(0.023) \\
{[0.128]}\end{array}$ & $\begin{array}{c}0.094^{* * *} \\
(0.022) \\
{[0.001]}\end{array}$ & $\begin{array}{c}0.051 \\
(0.035) \\
{[0.160]}\end{array}$ & $\begin{array}{c}0.071^{* * *} \\
(0.027) \\
{[0.022]}\end{array}$ \\
\hline Baseline controls & $\mathrm{X}$ & $\mathrm{X}$ & $\mathrm{X}$ & $\mathrm{X}$ & $\mathrm{X}$ & $\mathrm{X}$ \\
\hline Test: payroll $=$ account & 0.000 & 0.000 & 0.000 & 0.000 & 0.000 & 0.000 \\
\hline Observations & 1,311 & 1,311 & 1,311 & 1,311 & 1,311 & 1,311 \\
\hline R-squared & 0.094 & 0.068 & 0.250 & 0.256 & 0.153 & 0.353 \\
\hline Mean control [endline] & 0.402 & 0.252 & 0.081 & 0.049 & 0.613 & 0.120 \\
\hline
\end{tabular}

Notes: The table reports treatment effects on learning. Estimates in panel A are based on administrative data. The dependent variable is a dummy equal to one if at least one transaction was recorded in a given month. The omitted group consists of observations prior to random assignment to treatment, for which all outcomes are mechanically equal to zero. Robust standard errors, in parentheses, are clustered at the account level. Estimates in panel B are based on endline survey data. The omitted group consists of respondents in the control who continued to be paid in cash and did not receive an account. Controls include stratification dummies, marital status, number of dependents, dummies for savings, formal savings, years of work experience, and years with current employer. Robust standard errors in parentheses, sharpened q-values in brackets. ${ }^{*} p<0.1,{ }^{* *} p<0.05,{ }^{* * *} p<0.01$. 
Table 5

Trust in the Technology

\begin{tabular}{lccccc}
\hline \hline & \multicolumn{4}{c}{ Dependent variable } \\
\cline { 2 - 3 } \cline { 5 - 6 } & \multicolumn{2}{c}{ Bank account } & & Mobile money account \\
\cline { 2 - 3 } \cline { 5 - 6 } & Leave BDT & Leave BDT & & Leave BDT & Leave BDT \\
& 1,000 in account & 5,000 in account & 1,000 in account & 5,000 in account \\
& $(1)$ & $(2)$ & & $(3)$ & $(4)$ \\
\hline Bank or mobile payroll & 0.049 & 0.042 & & $0.168^{* * *}$ & $0.146^{* * *}$ \\
& $(0.030)$ & $(0.028)$ & & $(0.031)$ & $(0.028)$ \\
Bank or mobile account & {$[0.128]$} & {$[0.153]$} & & {$[0.001]$} & {$[0.001]$} \\
& 0.030 & 0.047 & & $0.082^{* *}$ & 0.035 \\
& $(0.049)$ & $(0.044)$ & & $(0.036)$ & $(0.033)$ \\
Baseline controls & {$[0.321]$} & {$[0.241]$} & & {$[0.049]$} & {$[0.241]$} \\
Sample & $\mathrm{X}$ & $\mathrm{X}$ & & $\mathrm{X}$ & $\mathrm{X}$ \\
Test: payroll = account & 0.688 & Bank+Contl & & Mobile+Contl & Mobile+Contl \\
Observations & 1,159 & 0.913 & & 0.014 & 0.001 \\
R-squared & 0.103 & 1,363 & & 1,311 & 1,559 \\
Mean control [endline] & 0.556 & 0.096 & & 0.112 & 0.103 \\
\hline
\end{tabular}

Notes: The table reports treatment effects on trust in the technology. The dependent variable in columns (1) and (3) is a dummy equal to one if a respondent indicates that they would be fully comfortable leaving an amount of BDT 1,000 in a bank or mobile money account respectively, for a period of one month. The dependent variable in columns (2) and (4) is a dummy equal to one if a respondent indicates that they would be comfortable to leave an amount of BDT 5,000 in a bank or mobile money account respectively, for a period of one month. The sample in columns (1) and (2) consists of the control group and respondents assigned to a bank account, the sample in columns (3) and (4) consists of the control group and respondents assigned to a mobile money account. Controls include stratification dummies, marital status, number of dependents, dummies for savings, formal savings, years of work experience, and years with current employer. Robust standard errors in parentheses, sharpened q-values in brackets. ${ }^{*} p<0.1$, ** $p<0.05,{ }^{* * *} p<0.01$. 
Table 6

Treatment Effects: Savings and Consumption

\begin{tabular}{|c|c|c|c|c|c|c|c|c|c|c|}
\hline & \multicolumn{10}{|c|}{ Dependent variable: } \\
\hline & \multicolumn{5}{|c|}{ Savings and remittances } & \multicolumn{5}{|c|}{ Consumption } \\
\hline & $\begin{array}{c}\text { Has any } \\
\text { savings } \\
(1)\end{array}$ & $\begin{array}{c}\text { Log total } \\
\text { savings } \\
\quad(2)\end{array}$ & $\begin{array}{c}\log \\
\text { formal } \\
\text { savings } \\
(3)\end{array}$ & $\begin{array}{c}\text { Log } \\
\text { informal } \\
\text { savings } \\
(4)\end{array}$ & $\begin{array}{l}\text { Log total } \\
\text { remit- } \\
\text { tances } \\
(5)\end{array}$ & $\begin{array}{l}\text { Log total } \\
\text { consump- } \\
\text { tion } \\
(6)\end{array}$ & $\begin{array}{l}\text { Log food } \\
\text { consump- } \\
\text { tion } \\
\quad(7)\end{array}$ & $\begin{array}{c}\text { Log } \\
\text { non-food } \\
\text { consumption } \\
(8)\end{array}$ & $\begin{array}{c}\text { Bought } \\
\text { item > Tk } \\
1,000 \\
(9)\end{array}$ & $\begin{array}{c}\text { Shocks } \\
\text { index } \\
(10)\end{array}$ \\
\hline & \multicolumn{10}{|c|}{ Panel A: endline } \\
\hline Bank or mobile payroll & $\begin{array}{c}0.038 * * \\
(0.019) \\
{[0.076]}\end{array}$ & $\begin{array}{c}0.508 * * \\
(0.198) \\
{[0.027]}\end{array}$ & $\begin{array}{c}2.424^{* * *} \\
(0.226) \\
{[0.001]}\end{array}$ & $\begin{array}{l}-0.333 \\
(0.203) \\
{[0.128]}\end{array}$ & $\begin{array}{l}-0.196 \\
(0.219) \\
{[0.249]}\end{array}$ & $\begin{array}{c}-0.116^{*} \\
(0.063) \\
{[0.095]}\end{array}$ & $\begin{array}{c}0.009 \\
(0.154) \\
{[0.502]}\end{array}$ & $\begin{array}{c}-0.135^{* *} \\
(0.063) \\
{[0.065]}\end{array}$ & $\begin{array}{c}-0.027^{*} \\
(0.015) \\
{[0.095]}\end{array}$ & $\begin{array}{c}-0.051 * * \\
(0.026) \\
{[0.080]}\end{array}$ \\
\hline Bank or mobile account & $\begin{array}{l}-0.005 \\
(0.024) \\
{[0.453]} \\
\end{array}$ & $\begin{array}{c}0.074 \\
(0.252) \\
{[0.427]}\end{array}$ & $\begin{array}{l}0.389 \\
(0.276) \\
{[0.160]} \\
\end{array}$ & $\begin{array}{l}-0.025 \\
(0.252) \\
{[0.494]} \\
\end{array}$ & $\begin{array}{l}0.054 \\
(0.276) \\
{[0.453]} \\
\end{array}$ & $\begin{array}{l}-0.092 \\
(0.079) \\
{[0.236]} \\
\end{array}$ & $\begin{array}{l}-0.174 \\
(0.191) \\
{[0.249]}\end{array}$ & $\begin{array}{l}-0.078 \\
(0.079) \\
{[0.245]} \\
\end{array}$ & $\begin{array}{l}-0.018 \\
(0.019) \\
{[0.245]} \\
\end{array}$ & $\begin{array}{l}-0.049 \\
(0.031) \\
{[0.130]} \\
\end{array}$ \\
\hline Baseline controls & $\mathrm{X}$ & $\mathrm{X}$ & $\mathrm{X}$ & $\mathrm{X}$ & $\mathrm{X}$ & $\mathrm{X}$ & $\mathrm{X}$ & $\mathrm{X}$ & $\mathrm{X}$ & $\mathrm{X}$ \\
\hline Test: payroll $=$ account & 0.036 & 0.041 & 0.000 & 0.155 & 0.297 & 0.747 & 0.268 & 0.439 & 0.561 & 0.918 \\
\hline Observations & 2,376 & 2,376 & 2,376 & 2,376 & 2,376 & 2,376 & 2,376 & 2,376 & 2,376 & 2,002 \\
\hline R-squared & 0.063 & 0.098 & 0.169 & 0.076 & 0.075 & 0.069 & 0.134 & 0.051 & 0.039 & 0.042 \\
\hline \multirow[t]{2}{*}{ Mean control [endline] } & 0.815 & 7.519 & 2.736 & 6.259 & 7.395 & 8.819 & 5.974 & 8.466 & 0.101 & 0.169 \\
\hline & \multicolumn{10}{|c|}{ Panel B: full panel } \\
\hline Bank or mobile payroll & $\begin{array}{c}0.110^{* * *} \\
(0.015) \\
{[0.001]}\end{array}$ & $\begin{array}{c}0.885 * * * \\
(0.144) \\
{[0.001]}\end{array}$ & $\begin{array}{c}1.322^{* * *} \\
(0.128) \\
{[0.001]}\end{array}$ & $\begin{array}{l}-0.146 \\
(0.122) \\
{[0.236]}\end{array}$ & $\begin{array}{l}-0.081 \\
(0.125) \\
{[0.403]}\end{array}$ & $\begin{array}{c}-0.077^{* *} \\
(0.038) \\
{[0.084]}\end{array}$ & $\begin{array}{c}0.066 \\
(0.110) \\
{[0.410]}\end{array}$ & $\begin{array}{c}-0.086^{* *} \\
(0.040) \\
{[0.067]}\end{array}$ & $\begin{array}{c}-0.016^{*} \\
(0.009) \\
{[0.122]}\end{array}$ & $\begin{array}{l}-0.013^{*} \\
(0.007) \\
{[0.099]}\end{array}$ \\
\hline Bank or mobile account & $\begin{array}{c}0.059 * * * \\
(0.019) \\
{[0.006]}\end{array}$ & $\begin{array}{c}0.576^{* * *} \\
(0.185) \\
{[0.006]}\end{array}$ & $\begin{array}{c}0.593^{* * *} \\
(0.159) \\
{[0.001]}\end{array}$ & $\begin{array}{c}0.182 \\
(0.170) \\
{[0.280]}\end{array}$ & $\begin{array}{l}-0.131 \\
(0.183) \\
{[0.397]}\end{array}$ & $\begin{array}{l}-0.043 \\
(0.055) \\
{[0.397]}\end{array}$ & $\begin{array}{c}0.110 \\
(0.155) \\
{[0.397]}\end{array}$ & $\begin{array}{l}-0.039 \\
(0.056) \\
{[0.397]}\end{array}$ & $\begin{array}{l}-0.017 \\
(0.014) \\
{[0.236]}\end{array}$ & $\begin{array}{l}-0.004 \\
(0.008) \\
{[0.463]}\end{array}$ \\
\hline Respondent fixed effects & $\mathrm{X}$ & $\mathrm{X}$ & $\mathrm{X}$ & $\mathrm{X}$ & $\mathrm{X}$ & $\mathrm{X}$ & $\mathrm{X}$ & $\mathrm{X}$ & $\mathrm{X}$ & $\mathrm{X}$ \\
\hline Test: payroll = account & 0.007 & 0.084 & 0.000 & 0.047 & 0.780 & 0.555 & 0.777 & 0.415 & 0.966 & 0.282 \\
\hline Observations & 16,286 & 16,286 & 16,286 & 16,286 & 13,415 & 13,436 & 13,436 & 13,435 & 13,429 & 8,467 \\
\hline R-squared & 0.074 & 0.051 & 0.022 & 0.157 & 0.049 & 0.012 & 0.046 & 0.017 & 0.001 & 0.001 \\
\hline Mean control [follow-up] & 0.440 & 4.304 & 2.533 & 2.158 & 4.510 & 8.812 & 6.773 & 8.292 & 0.068 & 0.020 \\
\hline
\end{tabular}

Notes: Treatment effects on savings and consumption. Panel A reports results based on the endline survey, Panel B reports results based on data from the midline follow-up and endline surveys. The omitted group in both panels consists of respondents in the control group who continued to be paid in cash and did not receive an account. Baseline controls include stratification dummies, marital status, number of dependents, dummies for savings, formal savings, years of work experience, and years with current employer. Robust standard errors in parentheses, sharpened q-values in brackets. ${ }^{*} p<0.1,{ }^{* *} p<0.05,{ }^{* * *} p<0.01$. 
Table 7

Machine Learning: GATES Analysis

\begin{tabular}{|c|c|c|c|}
\hline & $\begin{array}{c}\text { Most Affected } \\
\gamma_{5} \\
(1)\end{array}$ & $\begin{array}{c}\text { Least Affected } \\
\gamma_{1} \\
(2)\end{array}$ & $\begin{array}{c}\text { Difference } \\
\gamma_{5}-\gamma_{1} \\
(3)\end{array}$ \\
\hline & \multicolumn{3}{|c|}{ Panel A: savings and consumption } \\
\hline \multirow[t]{3}{*}{ Log total savings } & -0.025 & -0.293 & 0.300 \\
\hline & {$[1.000]$} & {$[1.000]$} & {$[1.000]$} \\
\hline & $(-0.820,0.821)$ & $(-0.990,0.636)$ & $(-0.954,1.340)$ \\
\hline \multirow[t]{3}{*}{ Log formal savings } & 0.524 & 0.598 & -0.168 \\
\hline & {$[0.596]$} & {$[0.604]$} & {$[1.000]$} \\
\hline & $(-0.461,1.199)$ & $(-0.346,1.616)$ & $(-1.480,1.265)$ \\
\hline \multirow[t]{3}{*}{ Log informal savings } & -0.488 & -0.191 & -0.209 \\
\hline & {$[0.791]$} & {$[1.000]$} & {$[1.000]$} \\
\hline & $(-1.802,0.813)$ & $(-1.239,0.674)$ & $(-1.894,1.525)$ \\
\hline \multirow[t]{3}{*}{ Log total remittances } & 0.003 & -0.563 & 0.496 \\
\hline & {$[1.000]$} & {$[0.667]$} & {$[1.000]$} \\
\hline & $(-1.347,1.201)$ & $(-1.798,0.398)$ & $(-1.965,2.984)$ \\
\hline \multirow[t]{3}{*}{ Log total consumption } & -0.024 & -0.494 & 0.465 \\
\hline & {$[1.000]$} & {$[0.006]$} & {$[0.049]$} \\
\hline & $(-0.335,0.295)$ & $(-0.828,-0.166)$ & $(0.053,0.910)$ \\
\hline \multirow[t]{4}{*}{ Shock index } & -0.027 & -0.073 & 0.055 \\
\hline & [1.000] & {$[0.807]$} & {$[1.000]$} \\
\hline & $(-0.172,0.100)$ & $(-0.220,0.076)$ & $(-0.153,0.237)$ \\
\hline & \multicolumn{3}{|c|}{ Panel B: account use and learning } \\
\hline \multirow[t]{3}{*}{ Deposits } & 0.065 & 0.031 & 0.039 \\
\hline & {$[0.601]$} & {$[0.762]$} & {$[1.000]$} \\
\hline & $(-0.057,0.184)$ & $(-0.037,0.136)$ & $(-0.174,0.211)$ \\
\hline \multirow[t]{3}{*}{ Withdrawals } & 1.298 & 0.802 & 0.498 \\
\hline & {$[0.000]$} & {$[0.000]$} & {$[0.000]$} \\
\hline & $(1.042,1.602)$ & $(0.567,1.007)$ & $(0.260,0.721)$ \\
\hline \multirow[t]{3}{*}{ Send-money } & 1.019 & 0.338 & 0.662 \\
\hline & {$[0.000]$} & {$[0.000]$} & {$[0.000]$} \\
\hline & $(0.705,1.280)$ & $(0.220,0.494)$ & $(0.307,0.953)$ \\
\hline \multirow[t]{3}{*}{ Total transactions } & 1.730 & 1.131 & 0.605 \\
\hline & {$[0.000]$} & {$[0.000]$} & {$[0.001]$} \\
\hline & $(1.289,2.167)$ & $(0.805,1.453)$ & $(0.217,0.996)$ \\
\hline \multirow[t]{3}{*}{ Direct transactions } & 0.536 & 0.224 & 0.304 \\
\hline & {$[0.000]$} & {$[0.000]$} & {$[0.000]$} \\
\hline & $(0.450,0.645)$ & $(0.152,0.305)$ & $(0.191,0.441)$ \\
\hline \multirow[t]{3}{*}{ Indirect transactions } & -0.099 & -0.277 & 0.193 \\
\hline & {$[0.274]$} & {$[0.002]$} & {$[0.136]$} \\
\hline & $(-0.204,0.014)$ & $(-0.446,-0.101)$ & $(-0.012,0.379)$ \\
\hline \multirow[t]{3}{*}{ Outside transactions } & 0.943 & 0.470 & 0.453 \\
\hline & {$[0.000]$} & {$[0.001]$} & {$[0.131]$} \\
\hline & $(0.571,1.164)$ & $(0.225,0.787)$ & $(-0.014,0.869)$ \\
\hline
\end{tabular}

Notes: The table reports sorted group average treatment effect coefficients for savings and mobile money payroll account use at endline. The sample is divided into $K=5$ groups, $\gamma_{K}$, based on the quintiles of the machine learning proxy predictor $S(Z)$. Medians over 100 splits. 90\% confidence intervals in parentheses, $p$-values for the hypothesis that the parameter is equal to zero in brackets. 
Table 8

Machine Learning: Classification Analysis (CLAN)

\begin{tabular}{|c|c|c|c|c|}
\hline & $\begin{array}{c}\text { Total } \\
\text { Consumption } \\
(1)\end{array}$ & $\begin{array}{c}\text { Total } \\
\text { Transactions } \\
(2)\end{array}$ & $\begin{array}{c}\text { Outside } \\
\text { Transactions } \\
\text { (3) }\end{array}$ & $\begin{array}{c}\text { Direct } \\
\text { Transactions } \\
\text { (4) }\end{array}$ \\
\hline Female & $\begin{array}{c}-0.295 \\
{[0.000]} \\
(-0.373,-0.214)\end{array}$ & $\begin{array}{c}-0.851 \\
{[0.000]} \\
(-0.904,-0.797)\end{array}$ & $\begin{array}{c}-0.774 \\
{[0.000]} \\
(-0.839,-0.710)\end{array}$ & $\begin{array}{c}-0.854 \\
{[0.000]} \\
(-0.926,-0.785\end{array}$ \\
\hline Married & $\begin{array}{c}-0.016 \\
{[1.000]} \\
(-0.100,0.064)\end{array}$ & $\begin{array}{c}-0.033 \\
{[0.975]} \\
(-0.123,0.060)\end{array}$ & $\begin{array}{c}-0.022 \\
{[1.000]} \\
(-0.113,0.069)\end{array}$ & $\begin{array}{c}-0.097 \\
{[0.224]} \\
(-0.215,0.023)\end{array}$ \\
\hline Dependent children & $\begin{array}{c}-0.079 \\
{[0.224]} \\
(-0.175,0.019)\end{array}$ & $\begin{array}{c}-0.158 \\
{[0.004]} \\
(-0.258,-0.057)\end{array}$ & $\begin{array}{c}-0.201 \\
{[0.000]} \\
(-0.300,-0.104)\end{array}$ & $\begin{array}{c}-0.335 \\
{[0.000]} \\
(-0.462,-0.209\end{array}$ \\
\hline Education & $\begin{array}{c}0.197 \\
{[0.330]} \\
(-0.082,0.481)\end{array}$ & $\begin{array}{c}1.337 \\
{[0.000]} \\
(1.011,1.654)\end{array}$ & $\begin{array}{c}1.682 \\
{[0.000]} \\
(1.364,2.003)\end{array}$ & $\begin{array}{c}1.694 \\
{[0.000]} \\
(1.319,2.073)\end{array}$ \\
\hline Literate & $\begin{array}{c}0.095 \\
{[0.128]} \\
(-0.006,0.195)\end{array}$ & $\begin{array}{c}0.236 \\
{[0.000]} \\
(0.141,0.331)\end{array}$ & $\begin{array}{c}0.380 \\
{[0.000]} \\
(0.289,0.472)\end{array}$ & $\begin{array}{c}0.301 \\
{[0.000]} \\
(0.172,0.430)\end{array}$ \\
\hline Digit span score & $\begin{array}{c}0.042 \\
{[1.000]} \\
(-0.216,0.296)\end{array}$ & $\begin{array}{c}0.687 \\
{[0.000]} \\
(0.420,0.942)\end{array}$ & $\begin{array}{c}0.734 \\
{[0.000]} \\
(0.491,0.980)\end{array}$ & $\begin{array}{c}0.612 \\
{[0.000]} \\
(0.298,0.930)\end{array}$ \\
\hline Experience in current job, years & $\begin{array}{c}-0.832 \\
{[0.000]} \\
(-1.199,-0.484)\end{array}$ & $\begin{array}{c}1.109 \\
{[0.000]} \\
(0.735,1.474)\end{array}$ & $\begin{array}{c}0.231 \\
{[0.466]} \\
(-0.151,0.604)\end{array}$ & $\begin{array}{c}0.650 \\
{[0.024]} \\
(0.141,1.163)\end{array}$ \\
\hline Expected tenure in job, years & $\begin{array}{c}0.753 \\
{[0.000]} \\
(0.413,1.073)\end{array}$ & $\begin{array}{c}0.484 \\
{[0.012]} \\
(0.146,0.801)\end{array}$ & $\begin{array}{c}-0.174 \\
{[0.585]} \\
(-0.515,0.151)\end{array}$ & $\begin{array}{c}0.743 \\
{[0.001]} \\
(0.312,1.179)\end{array}$ \\
\hline Ever used mobile money & $\begin{array}{c}0.397 \\
{[0.000]} \\
(0.313,0.481)\end{array}$ & $\begin{array}{c}0.190 \\
{[0.000]} \\
(0.102,0.276)\end{array}$ & $\begin{array}{c}0.174 \\
{[0.000]} \\
(0.089,0.257)\end{array}$ & $\begin{array}{c}0.350 \\
{[0.000]} \\
(0.241,0.460)\end{array}$ \\
\hline Income sharing & $\begin{array}{c}2.358 \\
{[0.797]} \\
(-3.182,7.966)\end{array}$ & $\begin{array}{c}6.065 \\
{[0.042]} \\
(0.939,11.28)\end{array}$ & $\begin{array}{c}3.582 \\
{[0.371]} \\
(-1.742,8.772)\end{array}$ & $\begin{array}{c}14.04 \\
{[0.000]} \\
(6.841,21.09)\end{array}$ \\
\hline Basic expenditures control & $\begin{array}{c}0.189 \\
{[0.000]} \\
(0.096,0.284)\end{array}$ & $\begin{array}{c}0.418 \\
{[0.000]} \\
(0.326,0.511)\end{array}$ & $\begin{array}{c}0.340 \\
{[0.000]} \\
(0.243,0.436)\end{array}$ & $\begin{array}{c}0.573 \\
{[0.000]} \\
(0.460,0.685)\end{array}$ \\
\hline Has savings & $\begin{array}{c}0.166 \\
{[0.002]} \\
(0.066,0.265)\end{array}$ & $\begin{array}{c}-0.060 \\
{[0.504]} \\
(-0.162,0.043)\end{array}$ & $\begin{array}{c}-0.022 \\
{[1.000]} \\
(-0.124,0.081)\end{array}$ & $\begin{array}{c}0.296 \\
{[0.000]} \\
(0.165,0.428)\end{array}$ \\
\hline Has formal savings & $\begin{array}{c}0.063 \\
{[0.243]} \\
(-0.023,0.147)\end{array}$ & $\begin{array}{c}0.008 \\
{[1.000]} \\
(-0.076,0.095)\end{array}$ & $\begin{array}{c}-0.019 \\
{[1.000]} \\
(-0.106,0.070)\end{array}$ & $\begin{array}{c}0.320 \\
{[0.000]} \\
(0.219,0.423)\end{array}$ \\
\hline Has loans & $\begin{array}{c}-0.068 \\
{[0.364]} \\
(-0.169,0.032)\end{array}$ & $\begin{array}{c}-0.011 \\
{[1.000]} \\
(-0.113,0.091)\end{array}$ & $\begin{array}{c}0.046 \\
{[0.753]} \\
(-0.056,0.149)\end{array}$ & $\begin{array}{c}0.005 \\
{[1.000]} \\
(-0.132,0.141)\end{array}$ \\
\hline Sent remittances & $\begin{array}{c}0.229 \\
{[0.000]} \\
(0.153,0.309)\end{array}$ & $\begin{array}{c}0.168 \\
{[0.000]} \\
(0.092,0.247)\end{array}$ & $\begin{array}{c}0.046 \\
{[0.444]} \\
(-0.028,0.117)\end{array}$ & $\begin{array}{c}0.262 \\
{[0.000]} \\
(0.165,0.354)\end{array}$ \\
\hline Need to borrow & $\begin{array}{c}0.095 \\
{[0.126]} \\
(-0.005,0.195)\end{array}$ & $\begin{array}{c}0.073 \\
{[0.290]} \\
(-0.029,0.176)\end{array}$ & $\begin{array}{c}0.120 \\
{[0.042]} \\
(0.018,0.221)\end{array}$ & $\begin{array}{c}0.097 \\
{[0.330]} \\
(-0.040,0.234)\end{array}$ \\
\hline Able to save $\mathrm{Tk} 5,000$ & $\begin{array}{c}0.021 \\
{[1.000]} \\
(-0.065,0.112)\end{array}$ & $\begin{array}{c}0.095 \\
{[0.043]} \\
(0.014,0.176)\end{array}$ & $\begin{array}{c}0.114 \\
{[0.007]} \\
(0.038,0.191)\end{array}$ & $\begin{array}{c}0.107 \\
{[0.124]} \\
(-0.006,0.218)\end{array}$ \\
\hline
\end{tabular}

Notes: Classification analysis for total consumption and mobile money person-to-person trans$\overline{\text { fers at }}$ endline. Columns (1) to (3) report results on total consumption, columns (4) to (6) report results on person-to-person mobile money transactions, both measured at endline. The sample is divided into $K=5$ groups, $\delta_{K}$, based on the quintiles of the CATE proxy predictor $S(Z)$. Medians over 100 splits. $90 \%$ confidence interval in parentheses, $p$-values for the hypothesis that the parameter is equal to zero in brackets. 
Table 9

Treatment Effects: Externalities from Technology Adoption

\begin{tabular}{lcccc}
\hline \hline & \multicolumn{4}{c}{ Dependent variable: } \\
\cline { 2 - 5 } & \multicolumn{4}{c}{ Extra charge $=1$} \\
\cline { 2 - 5 } & $(1)$ & $(2)$ & $(3)$ & $(4)$ \\
\hline Low adoption area & $0.151^{* * *}$ & & $0.151^{* * *}$ & 0.056 \\
& $(0.048)$ & & $(0.049)$ & $(0.034)$ \\
Low skill & & $0.443^{* * *}$ & $0.443^{* * *}$ & $0.387^{* * *}$ \\
& & $(0.115)$ & $(0.115)$ & $(0.111)$ \\
Low adoption area $\times$ Low skill & & & & 0.118 \\
& & & & $(0.075)$ \\
\hline Worker fixed effects & $\mathrm{X}$ & $\mathrm{X}$ & $\mathrm{X}$ & $\mathrm{X}$ \\
Week fixed effects & $\mathrm{X}$ & $\mathrm{X}$ & $\mathrm{X}$ & $\mathrm{X}$ \\
Observations & 504 & 504 & 504 & 504 \\
Clusters (\# neighborhoods) & 24 & 24 & 24 & 24 \\
R-squared & 0.142 & 0.145 & 0.171 & 0.173 \\
Mean dep.var & 0.310 & 0.310 & 0.310 & 0.310 \\
\hline
\end{tabular}

Notes: The table reports treatment effects from the audit study. The dependent variable in all regressions is an indicator equal to 1 if the customer was charged an illicit fee for receiving assistance with the transaction. "Low skill" is a treatment indicator for the low skill audit script assignment. "Low adoption area" is an indicator equal to one if the transaction takes place in a neighborhood with below median payroll account penetration, measured by the share of firms that have adopted payroll accounts. Robust standard errors, clustered by neighborhood, in parentheses. ${ }^{*} p<0.1,{ }^{* *} p<0.05,{ }^{* * *} p<0.01$. 


\section{Supplementary Appendix (For Online Publication)}

\section{A Appendix Figures}

Figure A.1

Bank and Mobile Money User Interface

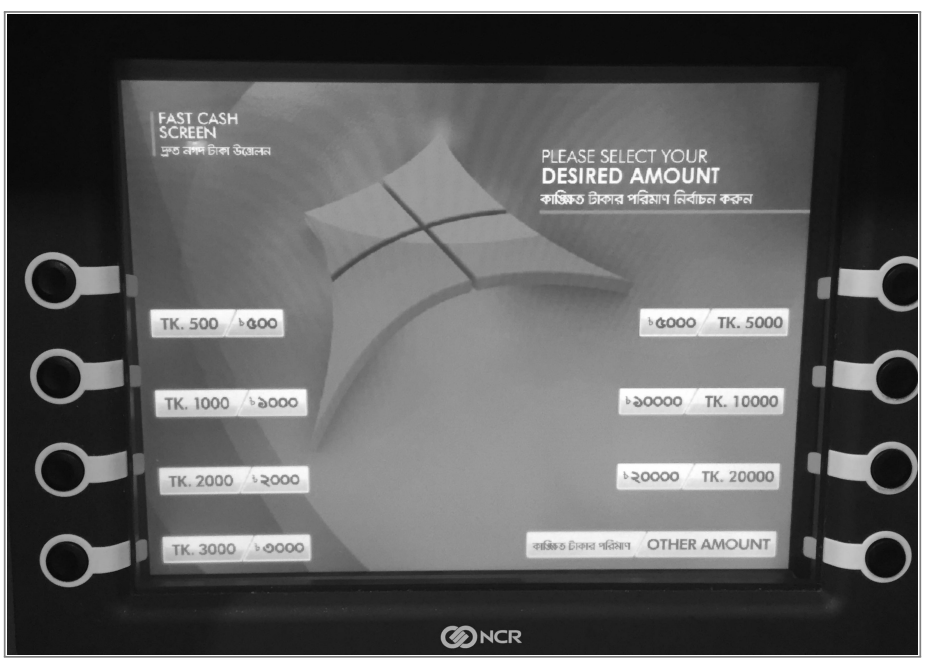

Notes: The figure shows the user interface of the ATM machines used in our experiment. The menu was customized to display text in English and Bangla. Users are able to make withdrawals only, using a bank issued card that can be used for debit transactions and at bank branches.

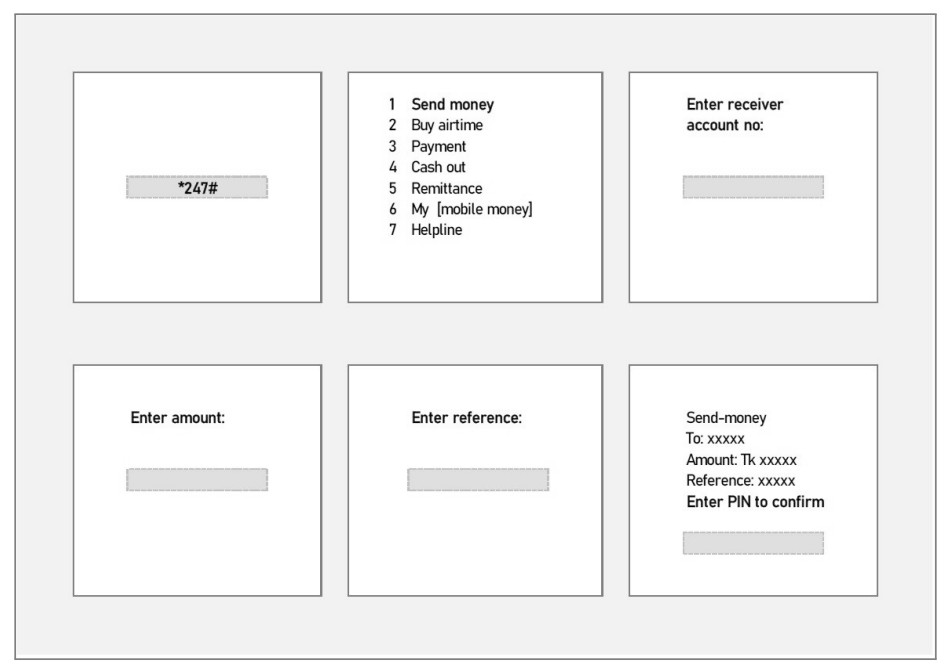

Notes: The figure shows the user interface of the mobile money platform used in the experiment. The menu is in English and looks identical on smart phones and conventional phones. Users are able to make payment, send-money, cash-in, cash-out, and buy airtime transactions. 


\section{B Timeline}

\begin{tabular}{|c|c|c|c|c|c|c|c|c|c|c|c|c|c|c|c|c|c|c|c|c|c|c|c|c|c|c|c|c|c|c|c|}
\hline & \multicolumn{10}{|c|}{2014} & \multicolumn{11}{|c|}{2015} & \multicolumn{10}{|c|}{2016} \\
\hline & $\mathrm{J}$ & $F M$ & A & M & $\mathrm{J} \mathrm{J}$ & A & $\mathrm{s}$ & 0 & $\mathrm{~N}$ & D & $\mathrm{J}$ & $\mathrm{F}$ & M & A & M & $\mathrm{J}$ & $\mathrm{J}$ & A & s & 01 & $N D$ & $\mathrm{~J}$ & $\mathrm{~F}$ & M & A & M. & $\mathrm{J} \mathrm{J}$ & J $A$ & $\mathrm{~s}$ & $0 \mathrm{~N}$ & $N D$ \\
\hline Experiment and survey & & & & & & & & & & & & & & & & & & & & & & & & & & & & & & & \\
\hline Baseline survey & & & & & & & & & & & & & & & & & & & & & & & & & & & & & & & \\
\hline [location $1+11]$ & & & & & & & & & & & & & & & & & & & & & & & & & & & & & & & \\
\hline Treatments & & & & & & & & & & & & & & & & & & & & & & & & & & & & & & & \\
\hline$[$ location I+ II] & & & & & & & & & & & & & & & & & & & & & & & & & & & & & & & \\
\hline Midline survey I & & & & & & & & & & & & & & & & & & & & & & & & & & & & & & & \\
\hline Midline survey II & & & & & & & & & & & & & & & & & & & & & & & & & & & & & & & \\
\hline Midline survey III & & & & & & & & & & & & & & & & & & & & & & & & & & & & & & & \\
\hline Midline survey IV & & & & & & & & & & & & & & & & & & & & & & & & & & & & & & & \\
\hline Midline survey V & & & & & & & & & & & & & & & & & & & & & & & & & & & & & & & \\
\hline Endline survey & & & & & & & & & & & & & & & & & & & & & & & & & & & & & & & \\
\hline [location I+ II] & & & & & & & & & & & & & & & & & & & & & & & & & & & & & & & \\
\hline Transaction data & & & & & & & & & & & & & & & & & & & & & & & & & & & & & & & \\
\hline Bank accounts & & & & & & & & & & & & & & & & & & & & & & & & & & & & & & & \\
\hline Mobile money accounts & & & & & & & & & & & & & & & & & & & & & & & & & & & & & & & \\
\hline
\end{tabular}

Notes: The figure shows the timeline of the surveys, intervention, and administrative data used in the main experiment. The experiment was conducted at two study sites. Survey dates shown indicate dates at which in-person surveys were conducted. Each survey round was accompanied by an additional phone survey, tracking respondents who were not present or no longer employed at the firm. Treatments were staggered over the time period indicated in the figure. 


\section{Scripts}

\section{C.1 Low-knowledge Script}

Customer: Assalamu'alaikum, do you offer [name of mobile money provider] service?

Agent: Yes. How can I help you?

Customer: I need to send some money to my home.

Agent: Ok, how much money do you want to send?

customer: 300 Taka.

Scenario 1

Agent: We don't do any transaction under 500 Taka or I cannot do the transaction for some other reason. You can try another mobile money agent. Sorry.

[Conversation ends.]

Scenario 2

Agent: We can do the transaction for you, but will charge you an extra [amount] taka.

Customer: No problem.

Scenario 3

Agent: Have you brought the number with you?

Customer: Yes. This is the number. [Worker passes the paper to the agent]

Agent: Is this a personal account or agent number?

Customer: I dont know. I am not familiar with [name of mobile money provider]. I dont know how it works.

Agent: Does the account holder run [name of mobile money provider] shop or business with this number or it is just his personal number?

Customer: He uses this number for his own mobile. He asked me to send money to this number.

Agent: That means it is a personal account. Do you want to include cash out charge with the amount so that when he cashes out the money he gets the full amount?

Customer: I dont know the fee for that. How much do I have to give you for sending 500 or 1,000 Taka?

Agent: That would be 510 or 1,020 Taka.

Customer: All right. Here is the money. Please send it to the number I gave you. 


\section{C.2 High-knowledge Script}

Customer: Assalamu'alaikum, do you offer [name of mobile money provider] mobile money service?

Agent: Yes. How can I help you?

Customer: I need your help with a transaction. I use my own account to do mobile money transactions all the time, like sending money using my own [name of mobile money provider] account. However, I am facing some trouble sending the money. I did everything exactly like before. First, I checked my balance to make sure there is enough money. After that, I selected the send money option, then I entered the account number and the amount of money and finally I used the correct password. But for some reason the transaction is not going through and I get an error message every time.

Scenario 1

Agent: We don't do any transaction under 500 Taka or I cannot do the transaction for some other reason. You can try another mobile money agent. Sorry

[Conversation ends.]

Scenario 2

Agent: I can do the transaction for you, but will charge you an extra [amount] taka.

Customer: No problem.

Scenario 3

Agent: No problem.

Agent: Have you brought the number with you?

Customer: Yes. This is the number. [Worker passes paper to the agent]

Agent: Is this a personal account or agent number?

Customer: This is a personal account.

Agent: Do you want to include cash out charge with the amount so that when he cashes out the money he gets the full amount?

Customer: Yes, please. Here is the money [give correct amount]. Please send this amount to the number I gave you. 


\section{Appendix Tables}

Table D.1

Summary Statistics: Transaction Data

\begin{tabular}{|c|c|c|c|c|c|c|}
\hline & $\mathrm{N}$ & Mean & Median & StDev & Min & Max \\
\hline & \multicolumn{6}{|c|}{ Panel A: bank and mobile money accounts } \\
\hline Deposits & 1,911 & 0.122 & 0.000 & 0.518 & 0.000 & 20.000 \\
\hline Withdrawals & 20,606 & 1.313 & 1.000 & 1.189 & 0.000 & 22.000 \\
\hline Send-money & 5,014 & 0.319 & 0.000 & 0.886 & 0.000 & 17.000 \\
\hline Total & 28,466 & 1.814 & 1.000 & 1.872 & 0.000 & 37.000 \\
\hline Excl. withdrawals & 7,860 & 0.501 & 0.000 & 1.299 & 0.000 & 27.000 \\
\hline Outside & 15,715 & 1.001 & 0.000 & 1.866 & 0.000 & 37.000 \\
\hline \multirow[t]{2}{*}{ Balance } & & 601.069 & 41.190 & 3237.861 & 0.000 & $9.0 \mathrm{e}+04$ \\
\hline & \multicolumn{6}{|c|}{ Panel B: bank accounts } \\
\hline Deposits & 46 & 0.005 & 0.000 & 0.076 & 0.000 & 2.000 \\
\hline Withdrawals & 12,108 & 1.390 & 1.000 & 1.181 & 0.000 & 22.000 \\
\hline Send-money & 0 & 0.000 & 0.000 & 0.000 & 0.000 & 0.000 \\
\hline Total & 12,154 & 1.395 & 1.000 & 1.198 & 0.000 & 22.000 \\
\hline Excl. withdrawals & 46 & 0.005 & 0.000 & 0.076 & 0.000 & 2.000 \\
\hline Outside & 2,767 & 0.318 & 0.000 & 0.896 & 0.000 & 22.000 \\
\hline \multirow[t]{2}{*}{ Balance } & & 733.071 & 60.100 & 3848.849 & 0.000 & $9.0 \mathrm{e}+04$ \\
\hline & \multicolumn{6}{|c|}{ Panel C: mobile money accounts } \\
\hline Deposits & 1,865 & 0.267 & 0.000 & 0.747 & 0.000 & 20.000 \\
\hline Withdrawals & 8,498 & 1.217 & 1.000 & 1.192 & 0.000 & 10.000 \\
\hline Send-money & 5,014 & 0.718 & 0.000 & 1.217 & 0.000 & 17.000 \\
\hline Total & 16,312 & 2.336 & 2.000 & 2.366 & 0.000 & 37.000 \\
\hline Excl. withdrawals & 7,814 & 1.119 & 1.000 & 1.759 & 0.000 & 27.000 \\
\hline Outside & 12,948 & 1.854 & 1.000 & 2.349 & 0.000 & 37.000 \\
\hline Balance & & 430.530 & 9.020 & 2199.890 & 0.000 & $4.7 \mathrm{e}+04$ \\
\hline
\end{tabular}

Notes: The table reports summary statistics for the bank and mobile money account transaction data. Bank transaction data is available from February 2015 to November 2016 and mobile money transaction data from May 2015 to November 2016. The data record all deposit, withdrawal, payment, and send-money transactions for a period of 22 months. 
Table D.2

Summary Statistics, Audit Study

\begin{tabular}{lcccccc}
\hline \hline & $\mathrm{N}$ & Mean & Median & StDev & Min & Max \\
\hline Extra charge & 504 & 0.310 & 0.000 & 0.463 & 0.000 & 1.000 \\
Number of firms per area & 504 & 6.008 & 5.000 & 2.650 & 3.000 & 12.000 \\
Number of mobile agents per area & 504 & 7.964 & 7.000 & 2.632 & 4.000 & 13.000 \\
Payroll account adoption, \% factories & 504 & 34.770 & 30.000 & 24.274 & 0.000 & 80.000 \\
Mobile agents per 1000 workers & 422 & 4.059 & 3.627 & 2.931 & 0.769 & 11.111 \\
\hline
\end{tabular}

Notes: The table reports summary statistics for the audit study experiment. Extra charge is a dummy equal to one of a worker was charged an illicit transaction fee. The study area was divided into 24 audit zones, audits were conducted by 38 workers over the course of ten weeks. 
Table D.3

First Stage: Treatment Status by Assigned Treatment

\begin{tabular}{lcc}
\hline \hline & \multicolumn{2}{c}{ Dependent variable: } \\
\cline { 2 - 3 } & $\begin{array}{c}\text { Treated } \\
(1)\end{array}$ & $\begin{array}{c}\text { Treated } \\
(2)\end{array}$ \\
\hline Bank or mobile payroll & $0.920^{* * *}$ & $1.004^{* * *}$ \\
& $(0.011)$ & $(0.003)$ \\
Bank or mobile account & $0.896^{* * *}$ & $0.983^{* * *}$ \\
& $(0.006)$ & $(0.014)$ \\
\hline Strata FE & & $\mathrm{X}$ \\
Factory Cluster & $\mathrm{X}$ & $\mathrm{X}$ \\
Test: payroll = account & 0.407 & 0.434 \\
Observations & 2,197 & 2,197 \\
R-squared & 0.914 & 0.916 \\
\hline
\end{tabular}

Notes: The table reports regressions of treatment status on treatment assignment for the main experiment. The dependent variable is an indicator equal to one if an individual in our sample was treated, where treatment is measured as receiving an account. Bank or mobile payroll assigned is an indicator equal to one if a participant was assigned to the bank or mobile payroll treatment, bank or mobile account assigned is an indicator equal to one if a participant was assigned to the one of the account only treatments. 


\section{D.1 Disaggregated Treatment Effects}

Table D.4

Disaggregated Treatment Effects: Account Use

\begin{tabular}{lcccccc}
\hline \hline & \multicolumn{5}{c}{ Dependent variable: } \\
\cline { 2 - 6 } & $\begin{array}{c}\text { Deposits } \\
(1)\end{array}$ & $\begin{array}{c}\text { Withdrawals } \\
(2)\end{array}$ & $\begin{array}{c}\text { Send-money } \\
(3)\end{array}$ & $\begin{array}{c}\text { Total } \\
(4)\end{array}$ & $\begin{array}{c}\text { Excl. withdrawals } \\
(5)\end{array}$ & $\begin{array}{c}\text { Balance } \\
(6)\end{array}$ \\
\hline Bank payroll & $0.002^{* *}$ & $0.747^{* * *}$ & 0.000 & $0.748^{* * *}$ & $0.003^{* * *}$ & $608.583^{* * *}$ \\
& $(0.001)$ & $(0.009)$ & $()$. & $(0.009)$ & $(0.001)$ & $(84.444)$ \\
Mobile payroll & $0.109^{* * *}$ & $0.531^{* * *}$ & $0.292^{* * *}$ & $0.630^{* * *}$ & $0.357^{* * *}$ & $305.888^{* * *}$ \\
& $(0.006)$ & $(0.011)$ & $(0.010)$ & $(0.012)$ & $(0.011)$ & $(49.724)$ \\
Bank account & $0.210^{* * *}$ & $0.387^{* * *}$ & 0.000 & $0.412^{* * *}$ & $0.211^{* * *}$ & $3012.336^{* *}$ \\
& $(0.042)$ & $(0.079)$ & $()$. & $(0.074)$ & $(0.042)$ & $(1396.125)$ \\
Mobile account & $0.044^{* * *}$ & $0.040^{* * *}$ & $0.021^{* * *}$ & $0.065^{* * *}$ & $0.063^{* * *}$ & $27.729^{* *}$ \\
& $(0.006)$ & $(0.005)$ & $(0.004)$ & $(0.008)$ & $(0.008)$ & $(11.210)$ \\
\hline Test: payroll = account [bank] & 0.000 & 0.000 &. & 0.000 & 0.000 & 0.086 \\
Test: payroll = account [mobile] & 0.000 & 0.000 & 0.000 & 0.000 & 0.000 & 0.000 \\
Observations & 40,458 & 40,458 & 24,046 & 40,458 & 40,458 & 40,458 \\
R-squared & 0.069 & 0.481 & 0.181 & 0.502 & 0.257 & 0.020 \\
\hline
\end{tabular}

Notes: Treatment effects on account use, disaggregated by type of account and based on administrative data. The dependent variable is a dummy equal to one if at least one transaction was recorded in a given calendar month. The omitted group consists of observations prior to random assignment to treatment, for which all outcomes are mechanically equal to zero. All regressions include strata fixed effects. Robust standard errors, clustered at the account level, in parentheses. ${ }^{*} p<0.1,{ }^{* *}$ $p<0.05,{ }^{* * *} p<0.01{ }^{*} p<0.1,{ }^{* *} p<0.05,{ }^{* * *} p<0.01$. 
Table D.5

Disaggregated Treatment Effects: Learning, Transactions Outside the Workplace

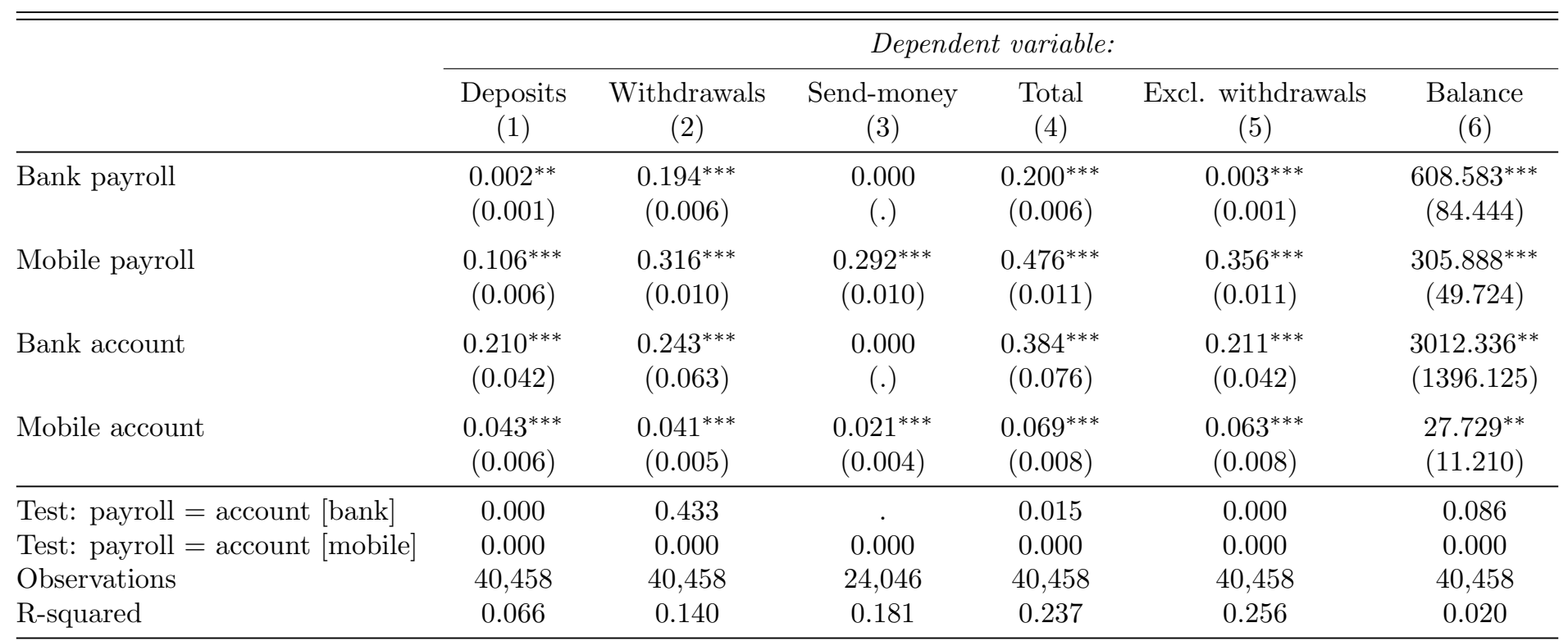

Notes: Treatment effects on learning (transactions outside the workplace), disaggregated by type of account and based on administrative data. The dependent variable in all columns is a dummy equal to one if at least one transaction of the type indicated in the column header was recorded in a given month. The omitted group consists of observations prior to random assignment to treatment, for which all outcomes are mechanically equal to zero. All regressions include strata fixed effects. Robust standard errors, clustered at the account level, in parentheses. ${ }^{*} p<0.1,{ }^{* *} p<0.05,{ }^{* * *} p<0.01$. 
Table D.6

Disaggregated Treatment Effects: Savings and Consumption, Endline Survey

\begin{tabular}{|c|c|c|c|c|c|c|c|c|c|c|}
\hline & \multicolumn{10}{|c|}{ Dependent variable: } \\
\hline & \multicolumn{5}{|c|}{ Savings and remittances } & \multicolumn{5}{|c|}{ Consumption } \\
\hline & $\begin{array}{c}\text { Has any } \\
\text { savings } \\
\text { (1) }\end{array}$ & $\begin{array}{c}\text { Log total } \\
\text { savings } \\
\quad(2)\end{array}$ & $\begin{array}{c}\log \\
\text { formal } \\
\text { savings } \\
(3)\end{array}$ & $\begin{array}{c}\text { Log } \\
\text { informal } \\
\text { savings } \\
(4)\end{array}$ & $\begin{array}{l}\text { Log total } \\
\text { remit- } \\
\text { tances } \\
(5)\end{array}$ & $\begin{array}{l}\text { Log total } \\
\text { consump- } \\
\text { tion } \\
(6)\end{array}$ & $\begin{array}{l}\text { Log food } \\
\text { consump- } \\
\text { tion } \\
(7)\end{array}$ & $\begin{array}{c}\text { Log } \\
\text { non-food } \\
\text { consumption } \\
(8)\end{array}$ & $\begin{array}{c}\text { Bought } \\
\text { item }>\mathrm{Tk} \\
1,000 \\
(9)\end{array}$ & $\begin{array}{c}\text { Shocks } \\
\text { index } \\
(10)\end{array}$ \\
\hline Bank payroll & $\begin{array}{c}0.098^{* * *} \\
(0.020)\end{array}$ & $\begin{array}{c}1.164^{* * *} \\
(0.209)\end{array}$ & $\begin{array}{c}4.366^{* * *} \\
(0.238)\end{array}$ & $\begin{array}{l}-0.204 \\
(0.228)\end{array}$ & $\begin{array}{l}-0.173 \\
(0.248)\end{array}$ & $\begin{array}{c}-0.144^{*} \\
(0.076)\end{array}$ & $\begin{array}{c}0.035 \\
(0.175)\end{array}$ & $\begin{array}{c}-0.154^{* *} \\
(0.076)\end{array}$ & $\begin{array}{l}-0.025 \\
(0.016)\end{array}$ & $\begin{array}{l}-0.041 \\
(0.028)\end{array}$ \\
\hline Bank account & $\begin{array}{c}0.020 \\
(0.036)\end{array}$ & $\begin{array}{c}0.439 \\
(0.373)\end{array}$ & $\begin{array}{c}0.588 \\
(0.395)\end{array}$ & $\begin{array}{c}0.389 \\
(0.372)\end{array}$ & $\begin{array}{c}0.276 \\
(0.430)\end{array}$ & $\begin{array}{c}0.011 \\
(0.115)\end{array}$ & $\begin{array}{c}0.217 \\
(0.277)\end{array}$ & $\begin{array}{c}0.000 \\
(0.117)\end{array}$ & $\begin{array}{l}-0.007 \\
(0.032)\end{array}$ & $\begin{array}{l}-0.054 \\
(0.042)\end{array}$ \\
\hline Mobile account & $\begin{array}{l}-0.016 \\
(0.027)\end{array}$ & $\begin{array}{l}-0.085 \\
(0.279)\end{array}$ & $\begin{array}{c}0.318 \\
(0.298)\end{array}$ & $\begin{array}{l}-0.201 \\
(0.279)\end{array}$ & $\begin{array}{l}-0.029 \\
(0.299)\end{array}$ & $\begin{array}{l}-0.134 \\
(0.090)\end{array}$ & $\begin{array}{l}-0.332 \\
(0.214)\end{array}$ & $\begin{array}{l}-0.110 \\
(0.089)\end{array}$ & $\begin{array}{l}-0.023 \\
(0.020)\end{array}$ & $\begin{array}{l}-0.047 \\
(0.033)\end{array}$ \\
\hline Baseline controls & $\mathrm{X}$ & $\mathrm{X}$ & $\mathrm{X}$ & $\mathrm{X}$ & $\mathrm{X}$ & $\mathrm{X}$ & $\mathrm{X}$ & $\mathrm{X}$ & $\mathrm{X}$ & $\mathrm{X}$ \\
\hline Test: payroll = account $[$ bank $]$ & 0.021 & 0.040 & 0.000 & 0.105 & 0.291 & 0.189 & 0.505 & 0.193 & 0.546 & 0.725 \\
\hline Test: payroll $=$ account $[$ mobile $]$ & 0.846 & 0.883 & 0.567 & 0.363 & 0.665 & 0.616 & 0.127 & 0.951 & 0.734 & 0.593 \\
\hline Mean control [endline] & 0.815 & 7.519 & 2.736 & 6.259 & 7.395 & 8.819 & 5.974 & 8.466 & 0.101 & 0.169 \\
\hline
\end{tabular}

Notes: Treatment effects on savings and consumption, disaggregated by type of account and based on data from the endline survey. The omitted category consists of participants in the control group who are paid in cash and did not receive an account. Controls include stratification dummies, marital status, number of dependents, dummies for savings, formal savings, years of work experience, and years with current employer. Robust standard errors in parentheses. ${ }^{*} p<0.1,{ }^{* *} p<0.05,{ }^{* * *} p<0.01$. 
Table D.7

Disaggregated Treatment Effects: Savings and Consumption, Full Survey Panel

\begin{tabular}{|c|c|c|c|c|c|c|c|c|c|c|}
\hline & \multicolumn{10}{|c|}{ Dependent variable: } \\
\hline & \multicolumn{5}{|c|}{ Savings and remittances } & \multicolumn{5}{|c|}{ Consumption } \\
\hline & $\begin{array}{c}\text { Has any } \\
\text { savings } \\
(1)\end{array}$ & $\begin{array}{l}\text { Log total } \\
\text { savings } \\
(2)\end{array}$ & $\begin{array}{c}\log \\
\text { formal } \\
\text { savings } \\
(3)\end{array}$ & $\begin{array}{c}\log \\
\text { informal } \\
\text { savings } \\
(4)\end{array}$ & $\begin{array}{l}\text { Log total } \\
\text { remit- } \\
\text { tances } \\
(5)\end{array}$ & $\begin{array}{l}\text { Log total } \\
\text { consump- } \\
\text { tion } \\
(6)\end{array}$ & $\begin{array}{l}\text { Log food } \\
\text { consump- } \\
\text { tion } \\
(7)\end{array}$ & $\begin{array}{c}\log \\
\text { non-food } \\
\text { consumption } \\
(8)\end{array}$ & $\begin{array}{c}\text { Bought } \\
\text { item > Tk } \\
1,000 \\
(9)\end{array}$ & $\begin{array}{c}\text { Shocks } \\
\text { index } \\
(10) \\
\end{array}$ \\
\hline Bank payroll & $\begin{array}{c}0.157^{* * *} \\
(0.018)\end{array}$ & $\begin{array}{c}1.225^{* * *} \\
(0.175)\end{array}$ & $\begin{array}{c}1.616^{* * *} \\
(0.155)\end{array}$ & $\begin{array}{l}-0.049 \\
(0.148)\end{array}$ & $\begin{array}{l}-0.134 \\
(0.155)\end{array}$ & $\begin{array}{c}-0.152^{* * *} \\
(0.050)\end{array}$ & $\begin{array}{l}-0.022 \\
(0.137)\end{array}$ & $\begin{array}{c}-0.144^{* * *} \\
(0.052)\end{array}$ & $\begin{array}{c}-0.024^{* *} \\
(0.012)\end{array}$ & $\begin{array}{c}-0.021^{* *} \\
(0.011)\end{array}$ \\
\hline Bank account & $\begin{array}{c}0.087^{* *} \\
(0.034)\end{array}$ & $\begin{array}{c}1.017^{* * *} \\
(0.323)\end{array}$ & $\begin{array}{c}0.695^{* * *} \\
(0.224)\end{array}$ & $\begin{array}{l}0.577^{*} \\
(0.320)\end{array}$ & $\begin{array}{l}-0.050 \\
(0.347)\end{array}$ & $\begin{array}{c}0.069 \\
(0.106)\end{array}$ & $\begin{array}{c}0.206 \\
(0.313)\end{array}$ & $\begin{array}{c}0.082 \\
(0.105)\end{array}$ & $\begin{array}{l}-0.041 \\
(0.032)\end{array}$ & $\begin{array}{l}-0.014 \\
(0.012)\end{array}$ \\
\hline Mobile account & $\begin{array}{c}0.048^{* *} \\
(0.021)\end{array}$ & $\begin{array}{c}0.419^{* *} \\
(0.202)\end{array}$ & $\begin{array}{c}0.550^{* * *} \\
(0.181)\end{array}$ & $\begin{array}{c}0.048 \\
(0.182) \\
\end{array}$ & $\begin{array}{c}-0.150 \\
(0.199) \\
\end{array}$ & $\begin{array}{c}-0.070 \\
(0.061) \\
\end{array}$ & $\begin{array}{c}0.087 \\
(0.167) \\
\end{array}$ & $\begin{array}{c}-0.068 \\
(0.062) \\
\end{array}$ & $\begin{array}{c}-0.010 \\
(0.014) \\
\end{array}$ & $\begin{array}{c}-0.001 \\
(0.009)\end{array}$ \\
\hline Respondent fixed effects & $\mathrm{X}$ & $\mathrm{X}$ & $\mathrm{X}$ & $\mathrm{X}$ & $\mathrm{X}$ & $\mathrm{X}$ & $\mathrm{X}$ & $\mathrm{X}$ & $\mathrm{X}$ & $\mathrm{X}$ \\
\hline Test: payroll = account [bank] & 0.047 & 0.533 & 0.000 & 0.056 & 0.813 & 0.044 & 0.479 & 0.037 & 0.604 & 0.590 \\
\hline Test: payroll = account [mobile] & 0.518 & 0.529 & 0.014 & 0.148 & 0.584 & 0.389 & 0.767 & 0.631 & 0.930 & 0.412 \\
\hline Mean control [follow-up] & 0.440 & 4.304 & 2.533 & 2.158 & 4.510 & 8.812 & 6.773 & 8.292 & 0.068 & 0.020 \\
\hline
\end{tabular}

Notes: Treatment effects on savings and consumption, disaggregated by type of account and based on data from the endline and midline followup surveys. The omitted category consists of workers in the control group who are paid in cash and did not receive an account. Controls include stratification dummies, marital status, number of dependents, dummies for savings, formal savings, years of work experience, and years with current employer. Robust standard errors in parentheses. ${ }^{*} p<0.1,{ }^{* *} p<0.05$, *** $p<0.01$. 
Table D.8 Trust

\begin{tabular}{|c|c|c|c|c|}
\hline & \multicolumn{4}{|c|}{ Dependent variable } \\
\hline & \multicolumn{2}{|c|}{ Bank account } & \multicolumn{2}{|c|}{ Mobile money account } \\
\hline & $\begin{array}{c}\text { Leave BDT } \\
1,000 \text { in account } \\
(1)\end{array}$ & $\begin{array}{c}\text { Leave BDT } \\
5,000 \text { in account } \\
(2)\end{array}$ & $\begin{array}{c}\text { Leave BDT } \\
1,000 \text { in account } \\
(3)\end{array}$ & $\begin{array}{c}\text { Leave BDT } \\
5,000 \text { in account } \\
\text { (4) }\end{array}$ \\
\hline Bank payroll & $\begin{array}{c}0.043 \\
(0.030)\end{array}$ & $\begin{array}{c}0.039 \\
(0.028)\end{array}$ & $\begin{array}{c}0.026 \\
(0.030)\end{array}$ & $\begin{array}{l}-0.006 \\
(0.028)\end{array}$ \\
\hline Mobile payroll & $\begin{array}{c}0.021 \\
(0.031)\end{array}$ & $\begin{array}{c}0.026 \\
(0.028)\end{array}$ & $\begin{array}{c}0.165^{* * *} \\
(0.030)\end{array}$ & $\begin{array}{c}0.144^{* * *} \\
(0.028)\end{array}$ \\
\hline Bank account & $\begin{array}{c}0.006 \\
(0.047)\end{array}$ & $\begin{array}{c}0.041 \\
(0.043)\end{array}$ & $\begin{array}{l}0.096^{*} \\
(0.051)\end{array}$ & $\begin{array}{c}0.069 \\
(0.047)\end{array}$ \\
\hline Mobile account & $\begin{array}{l}0.062^{*} \\
(0.036)\end{array}$ & $\begin{array}{c}0.015 \\
(0.034)\end{array}$ & $\begin{array}{c}0.082^{* *} \\
(0.036)\end{array}$ & $\begin{array}{c}0.036 \\
(0.033)\end{array}$ \\
\hline Baseline controls & $\mathrm{X}$ & $\mathrm{X}$ & $\mathrm{X}$ & $\mathrm{X}$ \\
\hline Test: payroll = account [bank] & 0.422 & 0.955 & 0.160 & 0.102 \\
\hline Test: payroll $=$ account $[$ mobile $]$ & 0.241 & 0.719 & 0.018 & 0.001 \\
\hline Observations & 2,002 & 2,375 & 2,002 & 2,375 \\
\hline R-squared & 0.085 & 0.075 & 0.087 & 0.088 \\
\hline Mean control [endline] & 0.556 & 0.558 & 0.380 & 0.377 \\
\hline
\end{tabular}

Notes: The table reports treatment effects on trust in bank and mobile money measured at endline, disaggregated by type of account. The dependent variable in columns (1) and (3) is a dummy equal to one if a respondent indicates that they would be comfortable to leave an amount of BDT 1,000 in a bank or mobile money account respectively, for a period of one month. The dependent variable in columns (2) and (4) is a dummy equal to one if a respondent indicates that they would be comfortable to leave an amount of BDT 5,000 in a bank or mobile money account respectively, for a period of one month. Controls include stratification dummies, marital status, number of dependents, dummies for savings, formal savings, years of work experience, and years with current employer. Robust standard errors in parentheses. ${ }^{*} p<0.1,{ }^{* *} p<0.05,{ }^{* * *} p<0.01$. 


\section{D.2 Robustness to Network Effects}

Table D.9

Robustness to Network Effects: Learning

\begin{tabular}{lcccccc}
\hline \hline & \multicolumn{5}{c}{ Dependent variable: } \\
\cline { 2 - 7 } & Agent-to-agent & Agent-to-person & Person-to-agent & Person-to-person & Indirect \\
& $(1)$ & $(2)$ & $(3)$ & $\begin{array}{c}\text { Direct } \\
(6)\end{array}$ \\
\hline Mobile payroll & $-0.194^{* * *}$ & $-0.059^{* *}$ & $0.365^{* * *}$ & $0.344^{* * *}$ & $-0.277^{* * *}$ & $0.497^{* * *}$ \\
& $(0.029)$ & $(0.027)$ & $(0.024)$ & $(0.023)$ & $(0.030)$ & $(0.025)$ \\
Mobile account & -0.030 & $0.094^{* * *}$ & $0.040^{*}$ & $0.093^{* * *}$ & 0.051 & $0.073^{* * *}$ \\
& $(0.037)$ & $(0.034)$ & $(0.023)$ & $(0.022)$ & $(0.035)$ & $(0.027)$ \\
Network & 0.169 & 0.455 & 7.649 & -0.502 & -1.374 & 6.782 \\
& $(6.396)$ & $(6.197)$ & $(4.998)$ & $(4.794)$ & $(6.484)$ & $(4.869)$ \\
Network treated payroll & 0.028 & -0.963 & -13.019 & -0.673 & 3.328 & -11.628 \\
& $(10.621)$ & $(10.475)$ & $(8.508)$ & $(7.983)$ & $(10.882)$ & $(8.124)$ \\
Network treated account & -1.826 & -0.426 & -7.784 & 7.891 & -4.255 & -6.333 \\
& $(11.063)$ & $(10.182)$ & $(8.885)$ & $(8.726)$ & $(11.434)$ & $(9.371)$ \\
\hline Baseline controls & $\mathrm{X}$ & $\mathrm{X}$ & $\mathrm{X}$ & $\mathrm{X}$ & $\mathrm{X}$ & $\mathrm{X}$ \\
Test: payroll = account & 0.000 & 0.000 & 0.000 & 0.000 & 0.000 & 0.000 \\
Observations & 1,311 & 1,311 & 1,311 & 1,311 & 1,311 & 1,311 \\
R-squared & 0.094 & 0.070 & 0.251 & 0.258 & 0.153 & 0.354 \\
Mean control [endline] & 0.402 & 0.252 & 0.081 & 0.049 & 0.613 & 0.120 \\
\hline
\end{tabular}

Notes: Treatment effects on learning based on survey data, controlling for the size of each respondent's network and the share of individuals treated within the network. The dependent variable in all columns is a dummy equal to one if at least one transaction of the type indicated in the column header was recorded in a given month. Network is defined for each worker as the number of workers from the same sub-district as worker $i$, employed by firm $k$, divided by the total number of workers employed by firm $k$. Network treated payroll is defined as the number of workers from the same sub-district as worker $i$, employed by firm $k$ and assigned to the payroll account treatment, divided by the total number of workers employed at firm $k$. Network treated account is defined as the number of workers from the same sub-district as worker $i$, employed by firm $k$ and assigned to the account treatment, divided by the total number of workers employed at firm $k$. The median worker has a network of 29 peers from their place of origin, of which $46.94 \%$ are assigned to the payroll account and $20.57 \%$ to the account only treatment. The omitted category consists of workers in the control group who continued to be paid in cash and did not receive an account. Controls include stratification dummies, marital status, number of dependents, dummies for savings, formal savings, years of work experience, and years with current employer. Robust standard errors in parentheses. ${ }^{*} p<0.1,{ }^{* *} p<0.05,{ }^{* * *} p<0.01$. 
Table D.10

Robustness to Network Effects: Savings and Consumption

\begin{tabular}{|c|c|c|c|c|c|c|c|c|c|c|}
\hline & \multicolumn{10}{|c|}{ Dependent variable: } \\
\hline & \multicolumn{5}{|c|}{ Savings and remittances } & \multicolumn{5}{|c|}{ Consumption } \\
\hline & $\begin{array}{c}\text { Has any } \\
\text { savings } \\
\text { (1) }\end{array}$ & $\begin{array}{c}\text { Log total } \\
\text { savings } \\
(2)\end{array}$ & $\begin{array}{c}\log \\
\text { formal } \\
\text { savings } \\
(3)\end{array}$ & $\begin{array}{c}\text { Log } \\
\text { informal } \\
\text { savings } \\
(4)\end{array}$ & $\begin{array}{l}\text { Log total } \\
\text { remit- } \\
\text { tances } \\
(5)\end{array}$ & $\begin{array}{l}\text { Log total } \\
\text { consump- } \\
\text { tion } \\
(6)\end{array}$ & $\begin{array}{l}\text { Log food } \\
\text { consump- } \\
\text { tion } \\
(7)\end{array}$ & $\begin{array}{c}\text { Log } \\
\text { non-food } \\
\text { consumption } \\
(8)\end{array}$ & $\begin{array}{c}\text { Bought } \\
\text { item > Tk } \\
1,000 \\
(9)\end{array}$ & $\begin{array}{c}\text { Shocks } \\
\text { index } \\
(10)\end{array}$ \\
\hline Bank or mobile payroll & $\begin{array}{l}0.036^{*} \\
(0.019)\end{array}$ & $\begin{array}{c}0.490^{* *} \\
(0.198)\end{array}$ & $\begin{array}{c}2.376^{* * *} \\
(0.225)\end{array}$ & $\begin{array}{l}-0.322 \\
(0.204)\end{array}$ & $\begin{array}{l}-0.157 \\
(0.218)\end{array}$ & $\begin{array}{c}-0.114^{*} \\
(0.063)\end{array}$ & $\begin{array}{l}-0.016 \\
(0.156)\end{array}$ & $\begin{array}{c}-0.131^{* *} \\
(0.064)\end{array}$ & $\begin{array}{c}-0.028^{*} \\
(0.015)\end{array}$ & $\begin{array}{c}-0.052^{* *} \\
(0.026)\end{array}$ \\
\hline Bank or mobile account & $\begin{array}{l}-0.004 \\
(0.024)\end{array}$ & $\begin{array}{c}0.078 \\
(0.251)\end{array}$ & $\begin{array}{c}0.423 \\
(0.271)\end{array}$ & $\begin{array}{l}-0.009 \\
(0.252)\end{array}$ & $\begin{array}{c}0.069 \\
(0.273)\end{array}$ & $\begin{array}{l}-0.096 \\
(0.079)\end{array}$ & $\begin{array}{l}-0.190 \\
(0.193)\end{array}$ & $\begin{array}{l}-0.081 \\
(0.079)\end{array}$ & $\begin{array}{l}-0.016 \\
(0.019)\end{array}$ & $\begin{array}{l}-0.049 \\
(0.031)\end{array}$ \\
\hline Network & $\begin{array}{l}-1.966 \\
(3.404)\end{array}$ & $\begin{array}{c}-30.750 \\
(35.058)\end{array}$ & $\begin{array}{c}-53.004 \\
(44.042)\end{array}$ & $\begin{array}{c}18.896 \\
(39.951)\end{array}$ & $\begin{array}{c}25.678 \\
(43.014)\end{array}$ & $\begin{array}{c}0.317 \\
(12.914)\end{array}$ & $\begin{array}{l}-38.269 \\
(30.280)\end{array}$ & $\begin{array}{c}3.572 \\
(12.955)\end{array}$ & $\begin{array}{c}1.423 \\
(2.551)\end{array}$ & $\begin{array}{l}-2.582 \\
(4.904)\end{array}$ \\
\hline Network treated payroll & $\begin{array}{c}4.664 \\
(5.786)\end{array}$ & $\begin{array}{c}63.930 \\
(59.424)\end{array}$ & $\begin{array}{l}107.061 \\
(74.021)\end{array}$ & $\begin{array}{l}-23.686 \\
(67.440)\end{array}$ & $\begin{array}{l}-44.345 \\
(72.559)\end{array}$ & $\begin{array}{c}-3.398 \\
(21.577)\end{array}$ & $\begin{array}{c}65.122 \\
(51.324)\end{array}$ & $\begin{array}{c}-8.805 \\
(21.645)\end{array}$ & $\begin{array}{l}-0.922 \\
(4.274)\end{array}$ & $\begin{array}{c}4.355 \\
(8.287)\end{array}$ \\
\hline Network treated account & $\begin{array}{l}-5.206 \\
(6.266)\end{array}$ & $\begin{array}{c}-29.421 \\
(64.339)\end{array}$ & $\begin{array}{c}-35.100 \\
(74.714)\end{array}$ & $\begin{array}{l}-67.749 \\
(69.620)\end{array}$ & $\begin{array}{l}-13.399 \\
(77.830)\end{array}$ & $\begin{array}{c}15.609 \\
(22.266)\end{array}$ & $\begin{array}{c}43.821 \\
(52.502)\end{array}$ & $\begin{array}{c}11.125 \\
(22.398)\end{array}$ & $\begin{array}{c}-9.038^{* *} \\
(4.608)\end{array}$ & $\begin{array}{c}1.971 \\
(8.037)\end{array}$ \\
\hline Baseline controls & $\mathrm{X}$ & $\mathrm{X}$ & $\mathrm{X}$ & $\mathrm{X}$ & $\mathrm{X}$ & $\mathrm{X}$ & $\mathrm{X}$ & $\mathrm{X}$ & $\mathrm{X}$ & $\mathrm{X}$ \\
\hline Test: payroll $=$ account & 0.052 & 0.052 & 0.000 & 0.148 & 0.343 & 0.810 & 0.294 & 0.492 & 0.423 & 0.914 \\
\hline Observations & 2,376 & 2,376 & 2,376 & 2,376 & 2,376 & 2,376 & 2,376 & 2,376 & 2,376 & 2,002 \\
\hline R-squared & 0.065 & 0.103 & 0.187 & 0.081 & 0.090 & 0.069 & 0.135 & 0.052 & 0.041 & 0.044 \\
\hline Mean control [endline] & 0.815 & 7.519 & 2.736 & 6.259 & 7.395 & 8.819 & 5.974 & 8.466 & 0.101 & 0.169 \\
\hline
\end{tabular}

Notes: The table reports treatment effects on savings and consumption based on survey data, controlling for the size of each respondent's network and the share of treated individuals in the network. Network is defined for each worker as the number of workers from the same sub-district as worker $i$, employed by firm $k$, divided by the total number of workers employed by firm $k$. Network treated payroll is defined as the number of workers from the same sub-district as worker $i$, employed by firm $k$ and assigned to the payroll account treatment, divided by the total number of workers employed at firm $k$. Network treated account is defined as the number of workers from the same sub-district as worker $i$, employed by firm $k$ and assigned to the account treatment, divided by the total number of workers employed at firm $k$. The median worker has a network of 29 peers from their place of origin, of which $46.94 \%$ are assigned to the payroll account and $20.57 \%$ to the account only treatment. The median worker has a network of 29 peers from their place of origin, of which $46.94 \%$ are assigned to the payroll account and $20.57 \%$ to the account only treatment. The omitted category consists of workers in the control group who continued to be paid in cash and did not receive an account. Controls include stratification dummies, marital status, number of dependents, dummies for savings, formal savings, years of work experience, and years with current employer. Robust standard errors in parentheses. ${ }^{*} p<0.1,{ }^{* *} p<0.05,{ }^{* * *} p<0.01$. 
Table D.11

Robustness to Network Effects: Trust

\begin{tabular}{|c|c|c|c|c|}
\hline & \multicolumn{4}{|c|}{ Dependent variable } \\
\hline & \multicolumn{2}{|c|}{ Bank account } & \multicolumn{2}{|c|}{ Mobile money account } \\
\hline & $\begin{array}{c}\text { Leave BDT } \\
1,000 \text { in account } \\
\text { (1) }\end{array}$ & $\begin{array}{c}\text { Leave BDT } \\
5,000 \text { in account } \\
\text { (2) }\end{array}$ & $\begin{array}{c}\text { Leave BDT } \\
1,000 \text { in account } \\
(3)\end{array}$ & $\begin{array}{c}\text { Leave BDT } \\
5,000 \text { in account } \\
\text { (4) }\end{array}$ \\
\hline Bank or mobile payroll & $\begin{array}{c}0.046 \\
(0.031)\end{array}$ & $\begin{array}{c}0.043 \\
(0.028)\end{array}$ & $\begin{array}{c}0.169^{* * *} \\
(0.031)\end{array}$ & $\begin{array}{c}0.145^{* * *} \\
(0.028)\end{array}$ \\
\hline Bank or mobile account & $\begin{array}{c}0.021 \\
(0.049)\end{array}$ & $\begin{array}{c}0.044 \\
(0.045)\end{array}$ & $\begin{array}{l}0.083^{* *} \\
(0.036)\end{array}$ & $\begin{array}{c}0.034 \\
(0.033)\end{array}$ \\
\hline Network & $\begin{array}{l}-9.609 \\
(6.770)\end{array}$ & $\begin{array}{l}-0.937 \\
(6.503)\end{array}$ & $\begin{array}{c}2.240 \\
(6.344)\end{array}$ & $\begin{array}{l}-3.270 \\
(5.834)\end{array}$ \\
\hline Network treated payroll & $\begin{array}{c}14.218 \\
(11.544)\end{array}$ & $\begin{array}{c}0.076 \\
(10.995)\end{array}$ & $\begin{array}{c}-2.279 \\
(10.749)\end{array}$ & $\begin{array}{c}6.024 \\
(9.822)\end{array}$ \\
\hline Network treated account & $\begin{array}{l}19.902^{*} \\
(11.433) \\
\end{array}$ & $\begin{array}{c}7.084 \\
(10.999) \\
\end{array}$ & $\begin{array}{c}-11.346 \\
(11.403) \\
\end{array}$ & $\begin{array}{c}0.155 \\
(10.574) \\
\end{array}$ \\
\hline Baseline controls & $\mathrm{X}$ & $\mathrm{X}$ & $\mathrm{X}$ & $\mathrm{X}$ \\
\hline Sample & Bank+Contl & Bank+Contl & Mobile+Contl & Mobile+Contl \\
\hline Test: payroll $=$ account & 0.606 & 0.985 & 0.015 & 0.001 \\
\hline Observations & 1,159 & 1,363 & 1,311 & 1,559 \\
\hline R-squared & 0.108 & 0.101 & 0.115 & 0.105 \\
\hline Mean control [endline] & 0.556 & 0.558 & 0.380 & 0.377 \\
\hline
\end{tabular}

Notes: The table reports treatment effects on trust in bank and mobile money based on survey data, controlling for the respondent's network and the share of treated individuals in the network. The dependent variable in columns (1) and (3) is a dummy equal to one if a respondent indicates that they would be comfortable to leave an amount of BDT 1,000 in a bank or mobile money account respectively, for a period of one month. The dependent variable in columns (2) and (4) is a dummy equal to one if a respondent indicates that they would be comfortable to leave an amount of BDT 5,000 in a bank or mobile money account respectively, for a period of one month. Network is defined for each worker as the number of workers from the same sub-district as worker $i$, employed by firm $k$, divided by the total number of workers employed by firm $k$. Network treated payroll is defined as the number of workers from the same sub-district as worker $i$, employed by firm $k$ and assigned to the payroll account treatment, divided by the total number of workers employed at firm $k$. Network treated account is defined as the number of workers from the same sub-district as worker $i$, employed by firm $k$ and assigned to the account treatment, divided by the total number of workers employed at firm $k$. The median worker has a network of 29 peers from their place of origin, of which $46.94 \%$ are assigned to the payroll account and $20.57 \%$ to the account only treatment. The omitted category consists of workers in the control group who continued to be paid in cash and did not receive an account. Controls include stratification dummies, marital status, number of dependents, dummies for savings, formal savings, years of work experience, and years with current employer. Robust standard errors in parentheses. ${ }^{*} p<0.1,{ }^{* *} p<0.05,{ }^{* * *} p<0.01$. 


\section{D.3 Workplace Outcomes}

Table D.12 shows impacts on wage earnings, as reported by the garment factories and on self-reported job satisfaction. We find that payroll accounts lead to significantly lower salary advances (column 5), which in turn raise salary payments received on pay day (column 1). We find suggestive negative impacts on labor supply, as measured by unpaid absences (column 4). We find the opposite patterns in the simple account treatments. One speculative explanation is that the simple bank accounts were more illiquid, requiring physical visits to a branch to make deposits.

Table D.12

Treatment Effects: Earnings and Work Satisfaction

\begin{tabular}{|c|c|c|c|c|c|c|}
\hline & \multicolumn{6}{|c|}{ Dependent variable: } \\
\hline & $\begin{array}{c}\text { Total payable } \\
\text { salary } \\
(1)\end{array}$ & $\begin{array}{c}\text { Overtime } \\
\text { payment } \\
(2)\end{array}$ & $\begin{array}{c}\text { Attendance } \\
\text { bonus } \\
(3)\end{array}$ & $\begin{array}{c}\text { Absence } \\
\text { deduction } \\
\quad(4)\end{array}$ & $\begin{array}{c}\text { Salary } \\
\text { advance } \\
(5)\end{array}$ & $\begin{array}{c}\text { Work } \\
\text { satisfaction } \\
(6)\end{array}$ \\
\hline Bank or mobile payroll & $\begin{array}{l}53.328^{* *} \\
(22.934)\end{array}$ & $\begin{array}{c}-2.097 \\
(14.769)\end{array}$ & $\begin{array}{l}-3.496 \\
(2.926)\end{array}$ & $\begin{array}{c}14.577^{* *} \\
(6.786)\end{array}$ & $\begin{array}{c}-88.961^{* * *} \\
(6.030)\end{array}$ & $\begin{array}{l}0.273^{* *} \\
(0.123)\end{array}$ \\
\hline Bank or mobile account & $\begin{array}{c}-84.665^{* *} \\
(34.582)\end{array}$ & $\begin{array}{l}-16.368 \\
(20.313)\end{array}$ & $\begin{array}{l}-6.201 \\
(4.066)\end{array}$ & $\begin{array}{l}-11.255 \\
(10.188)\end{array}$ & $\begin{array}{c}86.173^{* * *} \\
(9.254)\end{array}$ & $\begin{array}{c}0.291^{*} \\
(0.153)\end{array}$ \\
\hline Baseline controls & & & & & & $\mathrm{X}$ \\
\hline Test: payroll $=$ account & 0.000 & 0.443 & 0.497 & 0.016 & 0.000 & 0.893 \\
\hline Observations & 48,245 & 48,301 & 48,301 & 48,292 & 48,301 & 2,375 \\
\hline R-squared & 0.642 & 0.427 & 0.028 & 0.043 & 0.810 & 0.093 \\
\hline Mean control & 9041.824 & 1464.441 & 389.893 & 67.090 & 305.248 & 7.165 \\
\hline
\end{tabular}

Notes: The table reports treatment effects on earnings and work satisfaction based on survey data. Total payable salary is total monthly earnings including overtime and salary deductions. Overtime payment is the total monthly overtime earnings, attendance bonus is a bonus payment for not missing any work days in a given week. Salary advance are salary advances taken from the employer, which are deducted from the payable wage the next month. Work satisfaction is survey-elicited work satisfaction, measured at endline. The omitted category are participants in the control group who are paid in cash and did not receive an account. Controls include stratification dummies, marital status, number of dependents, dummies for savings, formal savings, years of work experience, and years with current employer. Robust standard errors in parentheses. ${ }^{*} p<0.1,{ }^{* *} p<0.05,{ }^{* * *} p<0.01$. 


\section{D.4 Additional Results}

Table D.13

Transactions Outside the Workplace, Excluding Weekends

\begin{tabular}{lcccccc}
\hline \hline & \multicolumn{5}{c}{ Dependent variable: } \\
\cline { 2 - 6 } & $\begin{array}{c}\text { Deposits } \\
(1)\end{array}$ & $\begin{array}{c}\text { Withdrawals } \\
(2)\end{array}$ & $\begin{array}{c}\text { Send-money } \\
(3)\end{array}$ & $\begin{array}{c}\text { Total } \\
(4)\end{array}$ & $\begin{array}{c}\text { Excl. withdrawals } \\
(5)\end{array}$ & $\begin{array}{c}\text { Balance } \\
(6)\end{array}$ \\
\hline Bank or mobile payroll & $0.044^{* * *}$ & $0.226^{* * *}$ & $0.256^{* * *}$ & $0.319^{* * *}$ & $0.173^{* * *}$ & $440.763^{* * *}$ \\
& $(0.003)$ & $(0.006)$ & $(0.010)$ & $(0.007)$ & $(0.007)$ & $(47.377)$ \\
Bank or mobile account & $0.039^{* * *}$ & $0.040^{* * *}$ & $0.016^{* * *}$ & $0.072^{* * *}$ & $0.061^{* * *}$ & $106.719^{* *}$ \\
& $(0.005)$ & $(0.004)$ & $(0.003)$ & $(0.007)$ & $(0.007)$ & $(47.498)$ \\
\hline Test: payroll = account & 0.445 & 0.000 & 0.000 & 0.000 & 0.000 & 0.000 \\
Observations & 40,458 & 40,458 & 24,046 & 40,458 & 40,458 & 40,458 \\
R-squared & 0.014 & 0.095 & 0.156 & 0.131 & 0.059 & 0.011 \\
\hline
\end{tabular}

Notes: The table reports treatment effects on transactions outside the workplace, excluding weekends, based on administrative data. The dependent variable is a dummy equal to one if at least one transaction was recorded in a given calendar month. The omitted group consists of observations prior to random assignment to treatment, for which all outcomes are mechanically equal to zero. All regressions include strata fixed effects. Robust standard errors, clustered at the account level, in parentheses. ${ }^{*} p$ $<0.1,{ }^{* *} p<0.05,{ }^{* * *} p<0.01$.

Table D.14

Transactions Outside the Workplace, Weekdays and Work Hours Only

\begin{tabular}{lcccccc}
\hline \hline & \multicolumn{5}{c}{ Dependent variable: } \\
\cline { 2 - 7 } & $\begin{array}{c}\text { Deposits } \\
(1)\end{array}$ & $\begin{array}{c}\text { Withdrawals } \\
(2)\end{array}$ & $\begin{array}{c}\text { Send-money } \\
(3)\end{array}$ & $\begin{array}{c}\text { Total } \\
(4)\end{array}$ & $\begin{array}{c}\text { Excl. withdrawals } \\
(5)\end{array}$ & $\begin{array}{c}\text { Balance } \\
(6)\end{array}$ \\
\hline Bank or mobile payroll & $0.031^{* * *}$ & $0.172^{* * *}$ & $0.191^{* * *}$ & $0.255^{* * *}$ & $0.131^{* * *}$ & $440.763^{* * *}$ \\
& $(0.002)$ & $(0.005)$ & $(0.008)$ & $(0.006)$ & $(0.006)$ & $(47.377)$ \\
Bank or mobile account & $0.030^{* * *}$ & $0.030^{* * *}$ & $0.011^{* * *}$ & $0.060^{* * *}$ & $0.049^{* * *}$ & $106.719^{* *}$ \\
& $(0.004)$ & $(0.004)$ & $(0.002)$ & $(0.006)$ & $(0.006)$ & $(47.498)$ \\
\hline Test: payroll = account & 0.865 & 0.000 & 0.000 & 0.000 & 0.000 & 0.000 \\
Observations & 40,458 & 40,458 & 24,046 & 40,458 & 40,458 & 40,458 \\
R-squared & 0.010 & 0.072 & 0.114 & 0.102 & 0.044 & 0.011 \\
\hline
\end{tabular}

Notes: The table reports treatment effects on transactions outside the workplace, based on administrative data, in a sample restricted to weekdays and work hours only. The dependent variable is a dummy equal to one if at least one transaction was recorded in a given calendar month. The omitted group consists of observations prior to random assignment to treatment, for which all outcomes are mechanically equal to zero. All regressions include strata fixed effects. Robust standard errors, clustered at the account level, in parentheses. ${ }^{*} p<0.1,{ }^{* *} p<0.05,{ }^{* * *} p<0.01$. 
Table D.15

Machine Learning: BLP Treatment Effects

\begin{tabular}{|c|c|c|}
\hline & $\begin{array}{c}\text { Average Treatment } \\
\text { Effect (ATE) } \\
(1)\end{array}$ & $\begin{array}{c}\text { Heterogeneous Treatment } \\
\text { Effect (HET) } \\
(2)\end{array}$ \\
\hline & \multicolumn{2}{|c|}{ Panel A: savings and consumption } \\
\hline \multirow[t]{3}{*}{ Log total savings } & -0.133 & 0.124 \\
\hline & {$[0.809]$} & {$[0.817]$} \\
\hline & $(-0.462,0.188)$ & $(-0.172,0.409)$ \\
\hline \multirow[t]{3}{*}{ Log formal savings } & 0.451 & -0.026 \\
\hline & {$[0.002]$} & {$[1.000]$} \\
\hline & $(0.171,0.735)$ & $(-0.335,0.289)$ \\
\hline \multirow[t]{3}{*}{ Log informal savings } & -0.306 & -0.044 \\
\hline & {$[0.120]$} & [1.000] \\
\hline & $(-0.616,0.011)$ & $(-0.590,0.424)$ \\
\hline \multirow[t]{3}{*}{ Log total remittances } & -0.188 & 0.196 \\
\hline & {$[0.419]$} & [1.000] \\
\hline & $(-0.558,0.108)$ & $(-0.578,0.918)$ \\
\hline \multirow[t]{3}{*}{ Log total consumption } & -0.125 & 0.374 \\
\hline & {$[0.129]$} & [0.003] \\
\hline & $(-0.269,0.009)$ & $(0.129,0.713)$ \\
\hline \multirow[t]{4}{*}{ Shock index } & -0.048 & 0.083 \\
\hline & [0.138] & [1.000] \\
\hline & $(-0.106,0.002)$ & $(-0.263,0.458)$ \\
\hline & \multicolumn{2}{|c|}{ Panel B: account use and learning } \\
\hline \multirow[t]{3}{*}{ Deposits } & 0.033 & 0.065 \\
\hline & {$[0.216]$} & {$[1.000]$} \\
\hline & $(-0.006,0.075)$ & $(-0.358,0.425)$ \\
\hline \multirow[t]{3}{*}{ Withdrawals } & 1.008 & 0.519 \\
\hline & {$[0.000]$} & {$[0.000]$} \\
\hline & $(0.869,1.142)$ & $(0.313,0.799)$ \\
\hline \multirow[t]{3}{*}{ Send-money } & 0.617 & 0.700 \\
\hline & {$[0.000]$} & {$[0.000]$} \\
\hline & $(0.501,0.717)$ & $(0.402,0.989)$ \\
\hline \multirow[t]{3}{*}{ Total Transactions } & 1.317 & 0.400 \\
\hline & {$[0.000]$} & {$[0.001]$} \\
\hline & $(1.105,1.526)$ & $(0.164,0.647)$ \\
\hline \multirow[t]{3}{*}{ Direct Transactions } & 0.344 & 0.689 \\
\hline & {$[0.000]$} & {$[0.000]$} \\
\hline & $(0.290,0.405)$ & $(0.414,0.947)$ \\
\hline \multirow[t]{3}{*}{ Indirect Transactions } & -0.202 & 0.398 \\
\hline & {$[0.000]$} & [0.188] \\
\hline & $(-0.254,-0.150)$ & $(-0.060,0.842)$ \\
\hline \multirow[t]{3}{*}{ Outside Transactions } & 0.610 & 0.290 \\
\hline & {$[0.000]$} & {$[0.015]$} \\
\hline & $(0.484,0.739)$ & $(0.071,0.517)$ \\
\hline
\end{tabular}

Notes: The table reports best linear predictor (BLP) treatment effects for savings and consumption (panel A), account use, and learning outcomes (panel B). Medians over 100 splits. 90\% confidence interval in parentheses, $p$-values for the hypothesis that the parameter is equal to zero in brackets.

$$
\text { xviii }
$$


Table D.16

Externalities from Consumer Learning, Robustness

\begin{tabular}{|c|c|c|c|c|c|c|c|c|}
\hline & \multicolumn{8}{|c|}{ Dependent variable: } \\
\hline & \multicolumn{8}{|c|}{ Extra charge $=1$} \\
\hline & (1) & $(2)$ & $(3)$ & (4) & $(5)$ & (6) & $(7)$ & (8) \\
\hline Low adoption area & $\begin{array}{c}0.150^{* * *} \\
(0.047)\end{array}$ & & $\begin{array}{c}0.150^{* * *} \\
(0.048)\end{array}$ & $\begin{array}{c}0.056 \\
(0.034)\end{array}$ & $\begin{array}{c}0.162^{* * *} \\
(0.049)\end{array}$ & & $\begin{array}{c}0.163^{* * *} \\
(0.049)\end{array}$ & $\begin{array}{c}0.042 \\
(0.039)\end{array}$ \\
\hline Low skill & & $\begin{array}{c}0.443^{* * *} \\
(0.115)\end{array}$ & $\begin{array}{c}0.443^{* * *} \\
(0.115)\end{array}$ & $\begin{array}{c}0.387^{* * *} \\
(0.111)\end{array}$ & & $\begin{array}{c}0.491^{* * *} \\
(0.121)\end{array}$ & $\begin{array}{c}0.494^{* * *} \\
(0.122)\end{array}$ & $\begin{array}{c}0.437^{* * *} \\
(0.118)\end{array}$ \\
\hline Low adoption area $\times$ Low skill & & & & $\begin{array}{c}0.118 \\
(0.075)\end{array}$ & & & & $\begin{array}{l}0.150^{* *} \\
(0.066)\end{array}$ \\
\hline Number of agents & $\begin{array}{l}-0.001 \\
(0.010)\end{array}$ & $\begin{array}{l}-0.004 \\
(0.011)\end{array}$ & $\begin{array}{l}-0.001 \\
(0.010)\end{array}$ & $\begin{array}{l}-0.001 \\
(0.010)\end{array}$ & & & & \\
\hline Number of agents per 1,000 workers & & & & & $\begin{array}{c}0.001 \\
(0.007)\end{array}$ & $\begin{array}{c}0.012 \\
(0.008)\end{array}$ & $\begin{array}{c}0.001 \\
(0.007)\end{array}$ & $\begin{array}{c}0.001 \\
(0.006)\end{array}$ \\
\hline Worker fixed effects & $\mathrm{X}$ & $\mathrm{X}$ & $\mathrm{X}$ & $\mathrm{X}$ & $\mathrm{X}$ & $\mathrm{X}$ & $\mathrm{X}$ & $\mathrm{X}$ \\
\hline Week fixed effects & $\mathrm{X}$ & $\mathrm{X}$ & $\mathrm{X}$ & $\mathrm{X}$ & $\mathrm{X}$ & $\mathrm{X}$ & $\mathrm{X}$ & $\mathrm{X}$ \\
\hline Observations & 504 & 504 & 504 & 504 & 422 & 422 & 422 & 422 \\
\hline Clusters (\# neighborhoods) & 24 & 24 & 24 & 24 & 24 & 24 & 24 & 24 \\
\hline R-squared & 0.142 & 0.145 & 0.171 & 0.173 & 0.162 & 0.174 & 0.197 & 0.201 \\
\hline Mean dep.var & 0.310 & 0.310 & 0.310 & 0.310 & 0.310 & 0.310 & 0.310 & 0.310 \\
\hline
\end{tabular}

Notes: The table reports robustness checks for the audit study. The dependent variable in all regressions is an indicator equal to 1 if the customer was charged an illicit fee for receiving help with the transaction. Low skill is a dummy for the low skill treatment condition. Low adoption area is an indicator for areas with below-median payroll account adoption. Mobile agents total is the number of mobile agents in the neighborhood, Mobile agents per worker is the number of mobile agents per 1,000 workers in the neighborhood. Robust standard errors, clustered by neighborhood, in parentheses. ${ }^{*} p<0.1, * * \mathrm{p}<0.05, * * * \mathrm{p}<0.01$. 